RICARDO HSIEH

\title{
Melanoma primário da mucosa oral: estudo imunoistoquímico e molecular da via da MAPK
}

Tese apresentada à Faculdade de Medicina da Universidade de São Paulo para obtenção do título de Doutor em Ciências

Programa de Dermatologia

Orientadora: Prof ${ }^{\mathrm{a}}$ Dra. Silvia Vanessa Lourenço

São Paulo

2012 


\section{Dados Internacionais de Catalogação na Publicação (CIP)}

Preparada pela Biblioteca da

Faculdade de Medicina da Universidade de São Paulo

Creprodução autorizada pelo autor

Hsieh, Ricardo

Melanoma primário da mucosa oral : estudo imunoistoquímico e molecular da via da MAPK / Ricardo Hsieh. -- São Paulo, 2012.

Tese(doutorado)--Faculdade de Medicina da Universidade de São Paulo.

Programa de Dermatologia.

Orientadora: Silvia Vanessa Lourenço.

Descritores: 1.Melanoma 2.Mucosa oral 3.Quinases de proteína quinase ativadas por mitógeno 4.Imunoistoquímica 5.Análise mutacional de DNA 6.Pirosequenciamento

USP/FM/DBD-123/12 


\section{DEDICATÓRIA}


Dedicatória

À Deus

Aos meus pais 
Agradecimentos

À minha orientadora, Prof ${ }^{a}$. Dra. Silvia Vanessa Lourenço, por acreditar no meu potencial, pelo seu incentivo a sempre progredir e alcançar meus objetivos profissionais, pelos seus ensinamentos e conselhos, pela paciência e dedicação como orientadora e uma grande amiga.

A todos os professores, colegas, profissionais técnicos e administrativos do Departamento de Dermatologia, pelos ensinamentos e suporte. Principalmente Dra. Mirian que sempre me incentivou, me auxiliou com seus conhecimentos e me ajudou a crescer profissionalmente.

A todos os professores, colegas, profissionais técnicos e administrativos do Instituto de Medicina Tropical, por permitir que eu desenvolva parte do meu trabalho, pela auxílio técnico, amizade e carinho de todos. Principalmente a Dirce, pois além dos ensinamentos técnicos e sua companhia diária no laboratório, sempre foi muito presente como amiga.

A todos os professores, colegas, profissionais técnicos do Hospital do Câncer A.C. Camargo, por permitir usar a infraestrutura e me auxiliarem em toda parte técnica 
de biologia molecular do meu trabalho. Principalmente, Cláudia, Marcilei, Renata e Rodrigo, pois sempre pude contar com o apoio profissional deles.

Ao Departamento de Patologia Geral da Faculdade de Odontologia da USP, pela oportunidade de estagiar pelo programa PAE na disciplina e contribuir com minha formação acadêmica.

A todos os meus parentes, entes queridos, amigos, colegas pela paciência, pelo carinho, pela amizade e por todo tipo de apoio que me deram durante todo a jronada, por sempre torcerem sempre por mim e acompanhando mais uma etapa profissional de minha vida, meu muito obrigado. Principalmente: Juliana, Sthefany, Paulo, Rubens, Marisa, Alexandre, Andréia, Fabiana, Rose, Sabrina, Fabio, Mauricio e outros que não citei, mas que moram no meu coração.

À FAPESP por acreditar e conceder auxílio à pesquisa para que este trabalho tenha sido realizado com êxito.

À CAPES por me contemplar com a bolsa de doutorado da pós-graduação, incentivando a minha formação profissional. 
Esta tese está de acordo com as seguintes normas, em vigor no momento desta publicação:

Referências: sistema autor-data; adaptado de: International Committee of Medical Journals Editors (Vancouver)

Universidade de São Paulo. Faculdade de Medicina. Divisão de Biblioteca e Documentação. Guia de apresentação de dissertações, teses e monografias. Elaborado por Anneliese Carneiro da Cunha, Maria Julia de A. L. Freddi, Maria F. Crestana, Marinalva de Souza Aragão, Suely Campos Cardoso, Valéria Vilhena. 3a ed. São Paulo: Divisão de Biblioteca e Documentação; 2011.

Abreviaturas dos títulos dos periódicos de acordo com List of Journals Indexed in Index Medicus. 


\section{SUMÁRIO}

Lista de abreviaturas

Lista de símbolos

Lista de figuras

Lista de gráficos

Lista de quadros

Resumo

Summary

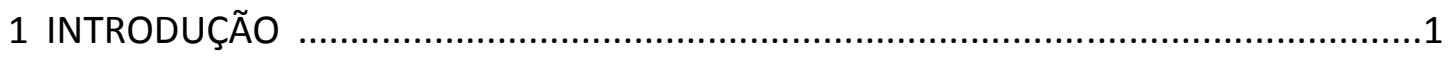

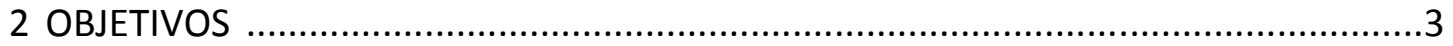

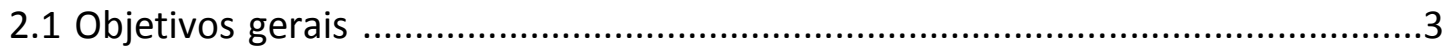

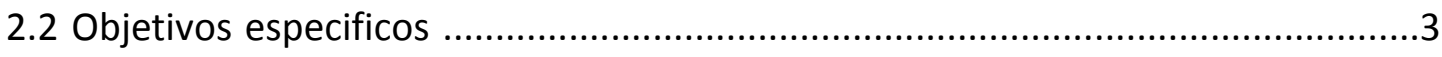

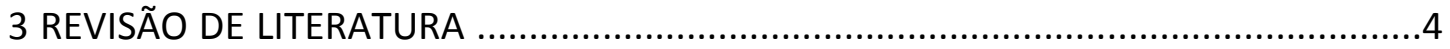

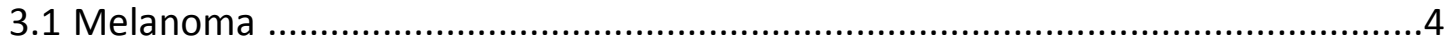

3.1.1 Melanoma: referências históricas .........................................................

3.1.2 Aspectos gerais do melanoma .................................................................

3.2 Melanoma primário da mucosa oral (MPMO) …...............................................10

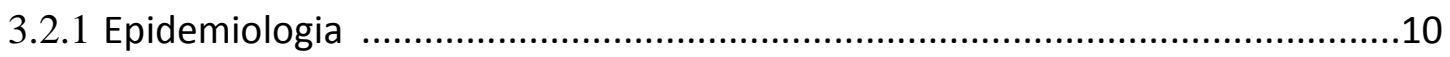

3.2.2 Características clínicas e histológicas do MPMO .......................................11

3.2.3 Etiologia do melanoma primário da mucosa oral ..........................................15 
3.3.1 Via da sinalização da MAPK ("mitogen activated protein kinase") ..................18

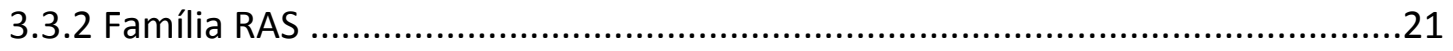

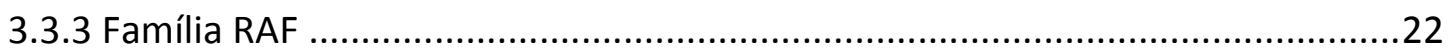

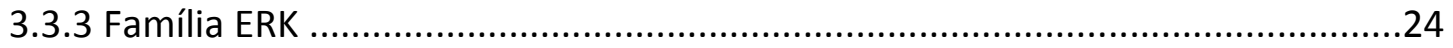

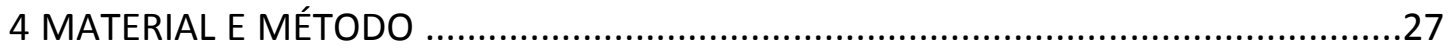

4.1 Etapa in situ de estudo da via MAPK em MPMO ..............................................29

4.1.1 Análise imunoistoquímica dos TMAs de melanomas orais ............................29

4.2. Etapa de estudo molecular da via MAPK em MPMO .......................................32

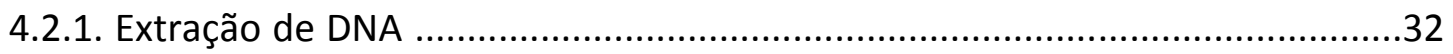

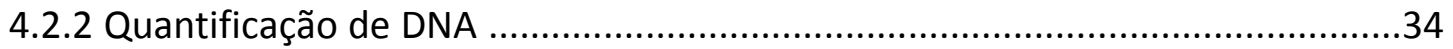

4.2.3 Amplificação por reação em cadeia da polimerase (PCR) ..............................34

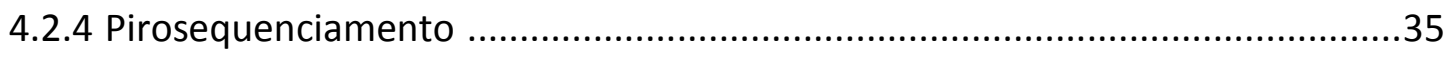

4.2.5 Análise dos dados obtidos pelo pirosequenciamento...................................38

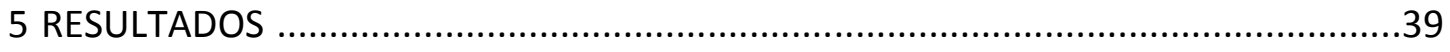

5.1 Resultados clínicos e histopatológicos analisados .......................................39

5.2 Resultados da análise imunoistoquímica dos TMAs de MPMO .........................53

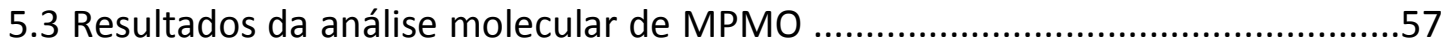

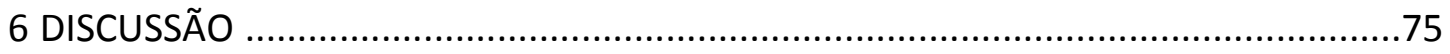

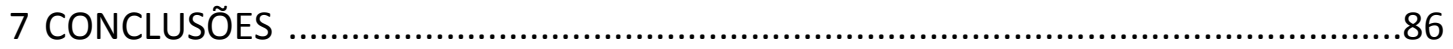

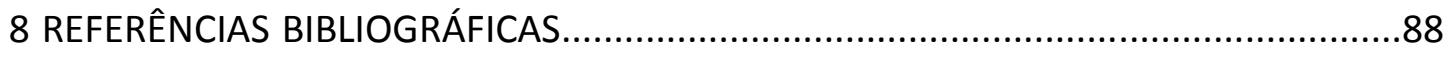




\section{Lista de abreviaturas}

et al.: e outros

in situ: no local

in vitro: em vidro

RTK: receptor de tirosina quinase

GTPase: enzima guanosina trifosfato

MAPK: mitogen activated protein kinase

RAS: homólogo do vírus RAS (rat sarcoma)

NRAS: homólogo do oncogene viral RAS do neuroblastoma

KRAS: homólogo oncogene viral de sarcoma de Kirsten

HRAS: homólogo oncogene viral de sarcoma de Harvey

ARAF: V-raf murine sarcoma 3611 viral oncogene homolog

BRAF: v-Raf murine sarcoma viral oncogene homolog B1

CRAF: V-raf-1 murine leukemia viral oncogene homolog 1

MEK Mitogen-activated protein kinase kinase

ERK: quinase regulada por sinal extracelular

p27: Cyclin-dependent kinase inhibitor 1B

TMA: tissue microarray

H/E: hematoxilina/eosina

A.C.: antes de Cristo

PCR: reação em cadeia da polimerase 
MPMO: melanoma primário da mucosa oral

WESTOP: Western Society of Teachers of Oral Pathology

DNA: ácido desoxirribonucléico

ATP: adenosina trifosfato

ADP: adenosina bifosfato

PPi: fosfato inorgânico

Pi: pirofosfato

$\mathrm{m}:$ meses

$\mathrm{XN}^{\circ}$ : número de vezes

UV: ultravioleta

BSA: bovine serum albumin

TRIS hidroximetil aminometano

SFB: soro fetal bovino

DNTP: deoxinucleotídeo trifosfatado 


\section{Lista de símbolos}

$\%$ : pocentagem

ml: mililitros

$\mu \mathrm{l}$ : microlitros

rpm: rotação por minuto

mM: milimolar

pmol: picomol

U: unidade

으 : graus Celsius 


\section{Lista de figuras}

Figura 1 Representação esquemática da via de sinalização da MAPK ............20

Figura 2 Exemplos dos aspectos histopatológicos de melanoma oral .............45

Figura 3 Exemplos dos aspectos histopatológicos de melanoma oral ............47

Figura $4 \quad$ Aspectos imunoistoquímicos da expressão das proteínas

componentes da via da MAPK nos MPMO....................................54

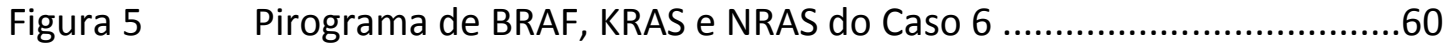

Figura 6 Pirogramas de BRAF, NRAS e KRAS do Caso 7 ................................61

Figura $7 \quad$ Pirogramas de BRAF, NRAS e KRAS do Caso 9 .................................62

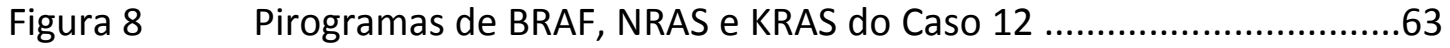

Figura 9 Pirogramas de BRAF, NRAS e KRAS do Caso 13 ...............................64

Figura 10 Pirogramas de BRAF, NRAS e KRAS do Caso 14 ..............................65

Figura 11 Pirograma de BRAF, NRAS e KRAS do Caso 17 .................................66

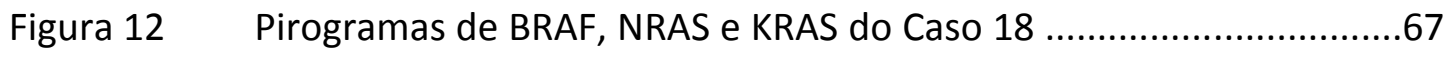

Figura 13 Pirograma de BRAF, NRAS e KRAS do Caso 19 .................................68

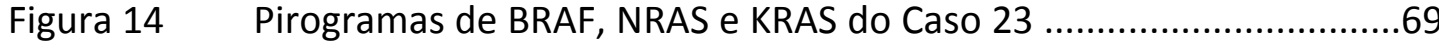

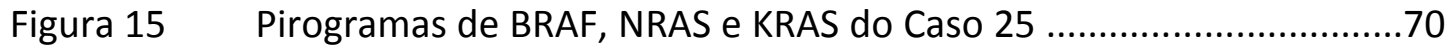

Figura 16 Pirogramas de BRAF, NRAS e /LRAS do Caso 26 ................................71

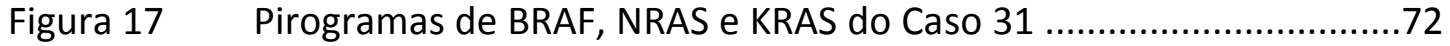

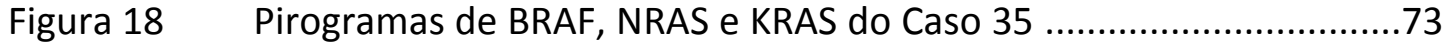

Figura 19 Pirogramas de BRAF, NRAS e KRAS dos controles positivos ..............74 


\section{Lista de Gráficos}

Gráfico 1 Distribuição do melanoma primário da mucosa oral segundo o gênero

(homens (51.43\%) e (48.57\%) mulheres) .........................................51

Gráfico 2 Distribuição do melanoma primário da mucosa oral por raça (brancos:

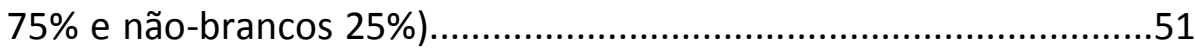

Gráfico 3 Localização das lesões de melanoma primário da mucosa oral ..........52

Gráfico 4 Análise do nível histológico dos melanomas primários da mucosa oral 


\section{Lista de Quadros}

Quadro 1 Primeira descrição clínica no idioma inglês de um caso de melanoma (William Norris, apud Davis e McLeod, 1998) .5

Quadro 2 Fragmento de descrição de laudo de necropsia de um caso de melanoma relatado por William Norris .......................................6

Quadro 3 Anticorpos primários, procedência, titulo e detalhes do protocolo ...31

Quadro 4 Detalhes clínicos derivados da revisão dos prontuários de cada caso

Quadro 6 Resumo das informações clínicas e histopatológicas dos 35 casos de melanoma primário da mucosa oral .49

Quadro 7 Relação entre recorrências e parâmetros histológicos dos melanomas estudados .50 
Quadro 8 Associação entre expressão das proteína da via MAPK e os parâmetros clínico-patológicos dos melanomas primários da mucosa

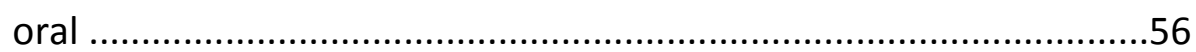

Quadro 9 Resultados do pirosequenciamento de BRAF; NRAS e KRAS nos 14

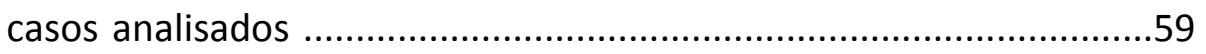


Hsieh R. Melanoma primário da mucosa oral: estudo imunoistoquímico e molecular da via da MAPK [tese]. São Paulo: Faculdade de Medicina, Universidade de São Paulo; 2012.

INTRODUÇÃO: O melanoma primário da cavidade oral é uma neoplasia agressiva, rara e originada a partir da proliferação de melanócitos malignos da mucosa. Ele representa aproximadamente de 0,2 a $8 \%$ de todos os melanomas. Estudos recentes apontam algumas vias moleculares tem sido encontradas por estarem envolvidas na patogenia dos melanomas. Dentre essas vias destaca-se a via proliferativa da MAPK (“mitogen activated protein kinase"), esta cascata de sinalização está envolvida no controle do crescimento celular, proliferação e migração, e tem sido relacionada com um papel importante no desenvolvimento e progressão do melanoma cutâneo. OBJETIVOS: Analisar a expressão proteica e mutação pontual dos componentes da via MAPK e correlacionar com os dados clínicos-histológicos. MATERIAL E MÉTODOS: Através da imunoistoquímica avaliar a expressão proteica dos anticorpos RAS; BRAF; MEK1; MEK2; ERK1 e ERK2 em 35 casos de melanomas orais organizados em matriz (TMA: Tissue Microarray) e através de pirosequenciamento avaliar a mutação pontual dos genes BRAF; NRAS; KRAS em 14 casos de melanomas orais. RESULTADOS: Idade dos pacientes entre 9 e 91 anos, sem predileção por sexo, 75\% caucasianos, $71,42 \%$ acometeram o palato, $80 \%$ com aspecto histológico grau III. A análise da expressão proteica foi: RAS (28,57\%); BRAF (82,85\%); MEK1 (0\%); MEK2 (51,43\%); ERK1 (20\%)e ERK2 (74,28\%). Na análise molecular observamos mutações para BRAF (9/14 casos) e NRAS (2/14 casos). CONCLUSÃO: Todos os aspectos da via 
MAPK necessita de outras elucidações em melanomas de áreas foto-protegidas e melanomas de mucosa e comparando diferentes populações. Entretanto, os resultados deste presente estudo apontam importante alterações na cascata RASRAF-MEK-ERK e estes são indicadores de prognóstico ruim em melanomas primários da mucosa oral, independente da exposição solar.
Descritores: 1) Melanoma
2) Mucosa oral
3) Quinases de proteína quinase
ativadas por mitógeno
4) Imunoistoquímica 5) Análise mutacional de DNA
6) Pirosequenciamento 
Hsieh R. Primary oral mucosal melanoma: an immunohistochemistry and molecular study of MAPK pathway [thesis]. São Paulo: Medicine School, University of São Paulo (Brazil); 2012.

BACKGROUND: Primary melanoma of the oral cavity is an aggressive and rare neoplasm and originated from the proliferation of malignant melanocytes of the mucosa. It represents approximately 0.2 to $8 \%$ of all melanomas. Recent studies indicate some molecular pathways have been found to be involved in the pathogenesis of melanomas. Among these means there is a proliferative MAPK pathway ("mitogen activated protein kinase"), this signaling pathway is involved in controlling cell growth, proliferation and migration, and it has been associated with a role in the development and progression of melanoma skin. OBJECTIVES: To analyze protein expression and mutation of components of the MAPK pathway and to correlate with the clinical, histological data. MATERIALS AND METHODS: Using immunohistochemistry to evaluate the protein expression of RAS, BRAF, MEK1, MEK2, ERK1 and ERK2 antibodies in 35 cases of oral melanomas organized array (TMA: Tissue Microarray) and using pyrosequencing to assess the mutation of the BRAF, NRAS, KRAS in 14 cases of oral melanomas. RESULTS: Age of patients between 9 and 91 years, regardless of gender, 75\% Caucasian, $71.42 \%$ in palate, $80 \%$ with histologic grade III. Analysis of protein expression was: RAS (28.57\%); BRAF (82.85\%); MEK1 (0\%), MEK2 (51.43\%); ERK1 (20\%) and ERK2 (74.28\%). Molecular 
analysis we found BRAF mutations (9/14 cases) and NRAS (2/14 cases). CONCLUSION: All aspects of the MAPK pathway requires further elucidation in melanomas of photo-protected areas and mucosal melanomas and comparing different populations. However, the results of this study indicate important changes in the cascade RAS-RAF-MEK-ERK and these are indicators of poor prognosis in primary melanomas of the oral mucosa, regardless of sun exposure.
Descriptors: 1) Melanoma
2) oral mucosa
3) kinases mitogen-activated
protein kinase
4) Immunohistochemistry
5) DNA mutational analysis
6) pyrosequencing 


\section{INTRODUÇÃO}

O melanoma é um tumor maligno que se desenvolve a partir da transformação maligna dos melanócitos, células produtoras de pigmento de melanina e derivadas da crista neural, que residem na camada basal da epiderme (Chudnovsky et al., 2005; Femiano et al., 2008). Mesmo compreendendo somente $3 \%$ de todos os tumores malignos da pele, é responsável por $60 \%$ de todas as mortes por neoplasias cutâneas (Kuphal e Bossenhoff, 2009). Embora a maior parte dos melanomas se desenvolvem na pele, eles também podem se desenvolver em superfícies de mucosa ou em quaisquer localizações em que as células da crista neural migram (Femiano et al., 2008).

Os melanomas de mucosa compreendem cerca de $1 \%$ de todos os melanomas e mostram um caráter biológico mais agressivo comparado ao que se observa nos melanomas cutâneos: apresentam maior taxa de comprometimento metastático para linfonodos e outros órgãos regionais e distantes, resultando num índice maior de mortalidade (Lengyel et al., 2003).

As mucosas mais comumente acometidas pelos melanomas estão na região da cabeça e pescoço (55\%), região anal/retal (24\%), trato genital feminino (18\%) e trato urinário (3\%), sendo a incidência do melanoma oral menor que 1,2 casos por 10 milhões de pessoas por ano (Hicks e Flaitz, 2000).

De acordo com Palmieri et al. (2009), mecanismos moleculares tem sido estudados na patogenia do melanoma, por estarem envolvidos na alteração clonal 
primária dos melanócitos neoplásicos, incluindo aqueles que induzem a proliferação celular (via proliferativa) ou superação da senescência celular (via de senescência).

Dentre essas vias moleculares envolvidas na patogenia do melanoma, destacase a via proliferativa a via do MAPK ("mitogen activated protein kinase") (incluindo a cascata de proteínas do NRAS, BRAF, MEK1/2 e ERK1/2). Esta via é apontada como a principal cascata de sinalização envolvida no controle do crescimento da população celular, proliferação e migração, e tem sido relacionada com um papel importante em ambos, desenvolvimento e progressão do melanoma cutâneo.

Entretanto, pouco se sabe a respeito da patogenia e os aspectos biológicos dos melanomas primários das mucosas, ao contrário dos diversos estudos encontrados para melanomas cutâneos. A literatura mostra que a via MAPK é de fundamental importância na proliferação de melanócitos de melanomas cutâneos. Nos melanomas da mucosa oral não há informações sobre a participação dessa via em quaisquer estágios da doença. Com a hipótese de que essa via possa ter abrigar importantes mutações que acarretem um pior comportamento clínico e prognóstico dos melanomas da mucosa oral, nosso trabalho se propõe a investigar seus componentes e correlacionar os resultados obtidos com os dados clínico-evolutivos dos casos de melanoma primário da mucosa oral que foram previamente selecionados pelo nosso grupo de trabalho. 


\section{OBJETIVOS}

\subsection{Objetivos gerais}

Estudar os componentes RAS, BRAF, MEK e ERK da via de sinalização da MAPK em melanomas primários da mucosa oral.

\subsection{Objetivos específicos}

1. analisar os padrões de expressão de: RAS, BRAF, MEK e ERK utilizando-se a técnica de imunoistoquímica em uma coleção de casos de melanoma primário da mucosa oral organizados em matriz (tissue microarray -TMA);

2. analisar mutação pontual dos genes BRAF, NRAS e KRAS em 14 casos de melanomas orais, por meio da técnica de pirosequenciamento;

3. correlacionar os dados obtidos nos experimentos de análise dos componentes da via MAPK com os dados clínico-evolutivos dos casos de melanoma primário da mucosa oral incluídos no estudo. 


\section{REVISÃO DA LITERATURA}

\subsection{MELANOMA}

\subsubsection{MELANOMA: REFERÊNCIAS HISTÓRICAS (Gray-Schopfer et al., 2006)}

Documentos de Hipócrates de cerca do século V A.C. sugerem que o melanoma foi identificado em múmias incas. Estudos arqueológicos posteriores, descrevem a neoplasia em múmias Incas do Peru e da região Andina, com metástases difusas em ossos do crânio e das extremidades (Chin et al., 1998; Chudnovsky et al., 2005 ).

A primeira publicação acerca de um caso de melanoma foi de John Hunter (cirurgião do St George's Hospital Medical School de Londres), em 1787. O espécime mantido no "Hunterian Museum of the Royal College of Surgeons" sob o número original de 219 refere-se a doença de um homem de 35 anos com uma massa recidivante no ângulo da mandíbula. Hunter descreveu a massa como uma "excrescência fúngica cancerosa". Apenas em 1968 o exame microscópico desse espécime revelou tratar-se de um melanoma.

Entretanto, a primeira descrição do melanoma é reputada a René Laennec. Sua descrição foi apresentada em forma de aula na Faculte de Medicine de Paris em 1804 e publicada em 1806. Logo após, em 1820, William Norris publicou o primeiro caso de melanoma na literatura de língua inglesa. Essa descrição original é reproduzida no Quadro 1. 
Quadro 1: Primeira descrição clínica no idioma inglês de um caso de melanoma (William Norris, apud Davis e McLeod, 1998)

"Mr D., aged 59 years, of light and fair complexion, presented to Dr. Norris on February 6, 1817 with a tumour on his abdominal wall midway between umbilicus and pubis. There had always been a mole on this position, but nine months previously, it began to grow and tumour developed. It was half the size of a hen's egg, of deep brown colour, of firm and fleshy feel, ulcerated, and discharging a highly foetid ichthorous fluid. The apex of the tumour was broader than its base. Some months after the tumour appeared, several distinct brown nodules sprang around it (satellites)."

The primary tumour was removed by the knife but then recurred in the scar in less than six weeks. The glands of the groin were swollen and slightly tender to the touch. Despite the disseminated nature of the tumour, the general health of the patient was not so much impaired as to interfere with his excercise or business. Multiple subcutaneous deposits developed with a distressing cough and dyspnea before he died.

Em 1857, Norris publicou uma coletânea de casos, sob o nome de "melanose", e concluiu que a doença ocorreria em pessoas com lesões em outras partes do corpo. Ele ainda relatou nesse artigo, o comportamento metastático do tumor, geralmente confirmado em necropsias (Quadro 2), e a possível tendência da predisposição hereditária da doença. 
Quadro 2: Fragmento de descrição de laudo de necropsia de um caso de melanoma relatado por William Norris (apud, Davis e Mc Leod, 1998)

... thousands and thousands of coal black spots, of circular shapes and various sizes on the shining mucous, serous and fibrous membranes of the vital organs as the most dazzling sight ever beheld by a morbid anatomist.

Norris foi um grande estudioso dos melanomas no século XIX, e uma série de princípios que envolvem sua epidemiologia e manejo clínico e análise histopatológica ainda persistem baseados em seus estudos. Segundo o médico clínico geral William Norris, melanoma se trata de uma doença hereditária, pois em seu manuscrito de 1820, ele descreveu uma família com numerosos sinais na pele e alguns membros da família com lesões metastáticas. Esta foi feita quase meio século antes do paradigma da genética articulada por Gregor Johann Mendel (Chin et al., 1998; Chudnovsky et al., 2005 ).

Ainda no século XIX, outros médicos tiveram importantes contribuições no estudo dos melanomas. Jean Cruveilier é autor das descrições originais de melanoma nas mãos, pés, vulva e metástases na mama e intestino, no livro "Anatomic Pathologique Du Corps Human", entre 1829 e 1842. Isaiah Parrish, em 1837, descreveu o primeiro caso de melanoma nos Estados Unidos e Sir James Paget, em 1853 escreveu uma de suas melhores peças no livro "Lectures on Surgical Pathology" a respeito de 
melanoma amelanótico. Ao final do século XIX, Sir Jonathan Huchtinson, em 1892 e 1894, descreveu casos de melanoma subungueal.

Estudado ao longo dos séculos por numerosos pioneiros na história da medicina, o melanoma foi retratado por desenhistas técnicos e até por Goya (o quadro Infanta Dona Maria Josefa parece retratar uma lesão na têmpora correspondente ao um lentigo maligno ou "Hutchinson's melananotic freckle"). No século XX, as pesquisas em melanomas floresceram, impulsionadas por avanços tecnológicos e hoje, oferecem subsídios para o desenvolvimento de terapêuticas que futuramente poderão ter impacto favorável na história natural da doença.

O avanço do conhecimento molecular nos últimos 20 anos confirmou a teoria de Norris da significância da contribuição genética na etiologia do melanoma (Chudnovsky et al., 2005 ).

\subsubsection{ASPECTOS GERAIS DO MELANOMA}

O melanoma é um tumor maligno que se desenvolve a partir da transformação maligna dos melanócitos, células produtoras de pigmento de melanina e derivadas da crista neural, que residem na camada basal da epiderme (Chudnovsky et al., 2005; Femiano et al., 2008). Embora a maior parte dos melanomas se desenvolvam na pele, eles também podem se desenvolver em superfícies de mucosa ou outros locais em que as células da crista neural migram (Femiano et al., 2008). 
O melanoma afeta igualmente homens e mulheres e é incomum em crianças. É, portanto, uma doença da fase adulta, diagnosticada, em média, na quarta década de vida. As localizações mais comuns dos melanomas da pele são o tronco (43.5\%), seguido pelas extremidades (33.9\%), cabeça e pescoço (10.7\%), e localização acral (11.9\%) (Kuphal e Bossenhoff, 2009).

Na maioria dos casos, o melanoma desenvolve-se como uma proliferação intraepidérmica de melanócitos neoplásicos que, por se mantém isolados na epiderme ou na derme superficial. Neste estágio de desenvolvimento, o melanoma é quase sempre curável com uma excisão cirúrgica adequada. As características biológicas essenciais da fase de crescimento radial do melanoma aparecem vagarosamente, mas com intensa proliferação de células atípicas na epiderme que podem ou não ser acompanhadas por uma migração neoplásica para as papilas dérmicas (Clark et al.,1990).

Em um estágio mais avançado a lesão pode formar nódulos expansivos e infiltrar a derme reticular ou gordura subcutânea. Nesta fase, denominada fase de crescimento vertical, a lesão adquire a capacidade de metastatizar e seu prognóstico é diretamente relativo à profundidade de invasão (Breslow, 1970). Outros parâmetros histológicos são importantes na determinação do comportamento biológico da neoplasia (Clark et al., 1969; Balch et al., 1980; Day et al., 1981; Day et al., 1982a; Day et al., 1982b; Day et al., 1982c; Day et al., 1982d; Harrist et al., 1984; Leon et al., 1991). Os melanomas de crescimento nodular e com fase de crescimento radial não detectável são classificados como melanomas nodulares. Os melanócitos neoplásicos 
dérmicos são grandes com núcleos proeminentes, muitas vezes nucléolos eosinofílicos, mas sem tendência a maturação. O índice mitótico é variável. Há perda estrutural da derme e perda da capacidade de formação de ninhos neoplásicos (Smoller et al., 2006).

A descrição prévia das fases de crescimento vertical e horizontal do melanoma pode ser aplicada em quase todos os exemplos de melanoma primário, embora, como já notado, nem todos os melanomas exibirão cada um destes compartimentos lesionais. Deste modo, aproximadamente $45 \%$ de casos novos são identificados na fase de crescimento radial, considerando que $10 \%$ apresentam somente a fase de crescimento vertical e os $45 \%$ restantes apresentam nódulo tumoral na fase de crescimento vertical circundado por uma placa na fase de crescimento radial. Esta hipótese de progressão de uma placa não-tumoral para um nódulo neoplásico que pode ter a capacidade de metastatizar tem implicação para o controle de mortalidade por melanoma desde que isto sugira que a progressão possa ser prevenida pela remoção de melanomas na fase de crescimento radial, quando as lesões são clinicamente placas não-tumorais e micro-invasivo histologicamente.

Aqueles melanomas que se apresentam com um nódulo tumoral na fase de crescimento vertical e sem evidente placa de crescimento radial na epiderme e papila dérmica adjacente (10\% dos casos) parecem representar melanomas nodulares desde o princípio, embora provavelmente a maioria deles tenha uma origem epidérmica (Elder e Murphy, 1991). 


\subsection{MELANOMA PRIMÁRIO DA MUCOSA ORAL (MPMO)}

\subsubsection{EPIDEMIOLOGIA}

O melanoma primário da mucosa oral é uma neoplasia de baixa ocorrência, de características agressivas e originada a partir da proliferação de melanócitos malignos da mucosa. Ele representa aproximadamente de 0,2 a $8 \%$ de todos os melanomas e 0,5\% de todas neoplasias orais na Austrália, Estados Unidos, Europa (Rapini et al., 1985; Hicks e Flaitz, 2000; Lee et al., 2002; Rapidis et al., 2003; Garzino-Demo et al., 2004; Femiano et al., 2008; Aguas et al., 2009; Sortino-Rachou et al., 2009). A doença tem sido relatada com maior frequência em asiáticos e negros; isso é atribuído parcialmente pelos comuns achados de pigmentação melânica na mucosa oral dessas raças (Aguas et al., 2009). Nos Estados Unidos, a proporção de melanomas de mucosa é maior $(8,8 \%)$ em afro-americanos e hispânicos do que na população em geral $(1,3 \%)$, enquanto Japão e Uganda revela-se uma doença relativamente freqüente (Lengyel et al., 2003). A incidência do MPMO no Japão é aproximadamente 11 - 24\%, maior do que em países ocidentais (Lee et al., 2002). Na nossa população a doença parece acometer com maior freqüência indivíduos brancos (Lourenço et al., 2009).

O melanoma primário da mucosa oral pode ocorrer em qualquer faixa etária sendo muito incomum em pessoas abaixo dos 30 anos de idade, geralmente entre 30 e 90 anos, sendo a maior incidência na $6^{\text {a }}$ década de vida (Lee et al., 2002; Aguas et al., 
2009; Sortino-Rachou et al., 2009). Geralmente não ocorre predileção ao sexo, porém alguns autores referem uma leve predileção pelo sexo feminino, outros referem ao masculino (Aguas et al., 2009).

Os locais de maior ocorrência são o palato e a gengiva superior (80\% dos melanomas orais) (Lourenço et al., 2009). Outras localizações incluem a gengiva inferior, mucosa jugal, língua e soalho bucal (Rapini et al., 1985; Hicks e Flaitz, 2000; Lee et al., 2002; Lengyel et al., 2003; Rapidis et al., 2003; Garzino-Demo et al., 2004; Aguas et al., 2009; Sortino-Rachou et al., 2009 ).

\subsubsection{CARACTERÍSTICAS CLÍNICAS E HISTOLÓGICAS DO MELANOMA PRIMÁRIO}

\section{DA MUCOSA ORAL}

O melanoma primário da mucosa oral é inicialmente assintomático e geralmente não perceptível ao doente, o qual contribui para o diagnóstico tardio (Femiano et al., 2008).

Seu aspecto clínico é variável sendo dividido em 5 tipos dependendo de suas características morfológicas em: pigmentado nodular, não-pigmentado nodular, pigmentado maculoso, pigmentado misto, não-pigmentado misto (Tanaka et al., 2004a, Tanaka et al., 2004b).

Histologicamente os melanomas orais são compostos de células fusiformes, plasmocitóides e epitelióides dispostas em lençóis, arranjos organóides, alveolar, 
neurotrópico e desmoplásico. Pigmento de melanina é encontrado em $90 \%$ das lesões. Maturação celular é ausente. Essas células mostram ainda alterações nucleares importantes como núcleos grandes e hipercromáticos, angulosos e por vezes múltiplos, com nucléolos proeminentes. Atividade mitótica é intensa. O padrão de invasão é notório com células neoplásicas ocupando até os níveis mais profundos da submucosa e destruindo e dissociando os tecidos subjacentes. (Smoller et al., 2006).

Muitos MPMO têm similaridade histológica com melanoma lentigo maligno na fase de crescimento radial, entretanto, quando começa a invasão, as lesões são muito agressivas e pode metastatizar semelhante à fase de crescimento vertical do melanoma extensivo superficial. Alguns descrevem MPMO como os melanomas palmar, plantar e subungueal, os quais são os tipos mais agressivos dos melanomas cutâneos, devendo ser classificado como melanoma lentiginoso acral (Femiano et al., 2008).

Os melanomas das mucosas da cabeça e pescoço têm comportamento supostamente mais agressivo que os melanomas da pele; eles têm uma maior tendência a metástases regionais e à distância, recorrências locais, regionais e em áreas distantes (Lengyel et al., 2003). Os locais mais comuns de metástases são os linfonodos, fígado e pulmão e acometimento generalizado nas fases avançadas da doença (Garzino-Demo et al., 2004). Ainda, diferentemente dos melanomas cutâneos, os melanomas mucosos exibem uma fase de crescimento vertical agressiva com rápido acometimento da submucosa e pior prognóstico. Em geral são detectados já em fase 
avançada e a maioria não apresenta fase radial de crescimento associada (crescimento superficial).

Em 1995 foi proposta uma classificação histológica específica para essas lesões primárias da cavidade oral na reunião anual da "Western Society of Teachers of Oral Pathology" que compreende na divisão das lesões em melanoma in situ, melanoma invasivo, melanomas combinados - in situ e invasivos, e proliferação melanocítica atípica que inclui qualquer lesão que apresente histopatologia atípica como núcleos hipercromáticos e angulados e atividade mitótica (Barker et al., 1997).

Parâmetros histopatológicos para avaliação da espessura dos melanomas cutâneos são, como regra, empregados na análise dos espécimes e têm valor preditivo da doença. Duas medidas fazem parte dos protocolos dos laudos dessas lesões medidas de Clark que analisam a profundidade da invasão tumoral, baseando-se nas estruturas anatômicas da pele e Breslow que mede numericamente a espessura tumoral a partir da superfície da pele. A análise desses parâmetros é recomendável nos melanomas mucosos, segundo a reunião de WESTOP, 1995, entretanto essa análise é difícil e nem sempre possível devido às características anatômicas regionais, tamanho das lesões e das biopsias e principalmente à deteç̧ão tardia das lesões que por ocasião de seu diagnóstico já se encontram em fases avançadas (Barker et al., 1997).

Em 2004, Prasad et al., em análise histopatológica de uma casuística de melanomas da cabeça e pescoço, propõe os seguintes critérios de estadiamento: 
Nível I: melanoma in situ: sem evidência de invasão ou com apenas microinvasão (definido como invasão individual ou pequenos ninhos com menos de 10 melanócitos atípicos próximos à junção epitélio/ lamina própria);

Nível II: invasão limitada à lâmina própria;

Nível III: invasão de planos profundos (músculo, osso, cartilagem, tecido adiposo).

Esta divisão de níveis representa os micro-compartimentos separados por barreiras teciduais que são facilmente identificadas sob análise de microscopia óptica. A progressão dos níveis microscópicos associa-se a piora clínica do quadro e sugere maior agressividade do tumor, podendo ser importante marcador do prognóstico.

Diagnósticos histopatológicos diferenciais dos melanomas incluem carcinoma epidermóide pouco diferenciado e linfomas. Análise imunoistoquímica para a detecção de proteínas específicas dos melanócitos é importante na diferenciação dessas possibilidades, sendo os melanomas positivos para S-100, vimentina, HMB-45, MelanA e tirosinase.

O prognóstico dos doentes com melanomas orais é sombrio com 5 anos de sobrevida estimados em 5 a 20\% dos doentes. A média de sobrevida para os melanomas orais é em torno de 2 anos a partir do diagnóstico (Chidzonga et al., 2007). Isto depende se há envolvimento de linfonodo (18 meses) ou não (46 meses) (Rapidis et al.,2003). O fator mais significativo para o prognóstico parece ser o estadio clínico, definido como: tumores localizados (Estadio I, $\mathrm{T}_{\text {qualquer }} \mathrm{N}_{0} \mathrm{M}_{0}$ ), tumores com metástase 
em linfonodo regional (Estadio II, $T_{\text {qualquer }} \mathrm{N}_{1} \mathrm{M}_{0}$ ), e tumores com metástases em locais distantes (Estadio III, $\mathrm{T}_{\text {qualquer }} \mathrm{N}_{\text {qualquer }} \mathrm{M}_{1}$ ) (Prasad et al., 2004). Em geral, fatores prognósticos para uma pior sobrevida incluem localização do tumor primário, estágio no momento do diagnóstico, espessura tumoral maior que $5 \mathrm{~mm}$, presença ou ausência de invasão vascular, e desenvolvimento de metástases em linfonodos ou à distância (Garzino-Demo et al., 2004; Patel et al., 2002; Gu et al., 2003; Mendenhall et al., 2005). Entretanto, recentemente tem sido mostrado que a espessura tumoral, invasão vascular e necrose não têm influência significante na sobrevida (Prasad et al., 2004). Maior espessura do tumor, nível e fase de crescimento vertical do tumor têm sido associadas a um pior prognóstico (Garzino-Demo et al., 2004; Chidzonga et al., 2007).

\subsubsection{ETIOLOGIA DO MELANOMA PRIMÁRIO DA MUCOSA ORAL}

A etnia e exposição ao sol parecem ter grande influência no desenvolvimento do melanoma cutâneo. A luz ultravioleta-B é considerado o fator mais importante durante a exposição solar. Melanoma da mucosa, por outro lado, não tem associação com exposição solar. Tabagismo, alcoolismo e irritação dentária são alguns fatores de risco, mas a correlação é infundada e os fatores de riscos permanecem obscuros (Chudnovsky et al., 2005; Femiano et al., 2008; Aguas et al., 2009).

Em contraste com os fatores etiológicos bem estabelecidos na participação da evolução do melanoma da pele, tais fatores que não são levados em consideração 
(exposição solar, fraca tendência em bronzear) ou aqueles ainda não foram estudados extensivamente (história familiar, síndromes, defeitos citogenéticos) com melanoma das mucosas da cavidade oral e região da cabeça e pescoço. Provavelmente a maior razão para carência de conhecimento sobre melanoma de mucosa é a raridade dessa malignidade (Hicks e Flaitz, 2000).

Embora existam informações na literatura sobre dados clínicos, epidemiológicos e tentativas de classificação histopatológica dos melanomas da mucosa, essas são escassas e, na sua grande maioria baseadas em relatos de casos. Com relação aos mecanismos subcelulares que participam da biologia do melanoma da mucosa oral, estes são quase que completamente desconhecidos, a despeitos dos melanomas cutâneos, onde já se conhecem diversos mecanismos moleculares alterados no tumor. Entre esses mecanismos, destaca-se a via da MAPK ("mitogen activated protein kinase"), que está envolvida nos processos de crescimento, sobrevivência e migração celular.

\subsection{GENÉTICA MOLECULAR DO MELANOMA PRIMÁRIO DA MUCOSA ORAL}

Nos dias atuais, as pesquisas mostram forte evidência do conceito de que o melanoma tem correlação com eventos genéticos. Essa posição tem sido reforçada pela identificação "hot spots" genômicos (e seus genes residentes) cuja alteração estrutural se correlaciona com a gênese e/ou progressão do melanoma (Chin et al., 
2006). A força motriz por trás da iniciação e progressão do desenvolvimento do melanoma é a aquisição de mutações somáticas nos genes reguladores de importantes mecanismos de proliferação e senescência celular (Dahl e Guldberg, 2007).

Por mais de 20 anos, um grande número de laboratórios pelo mundo todo têm participado na busca de genes relacionados ao desenvolvimento do melanoma, reforçando a participação de eventos genéticos na fisiopatologia do tumor (mutação de gene, deleção, amplificação ou translocação) e de epigenética (alteração transmissível não sendo na sequência do DNA, geralmente modulação transcricional pela metilação do DNA e/ou alteração da cromatina, como modificação da histona) (Dahl e Guldberg, 2007; Palmieri et al., 2009).

Neste sentido, diversos estudos conduzidos ao longo de várias décadas em espécimes de lesões melanocíticas benignas e malignas bem como em linhagens de células de melanoma tem implicado numerosos genes no desenvolvimento e progressão da doença (Chin et al., 2006). Estes fatores incluem iniciação do tumor (mutações, perda de heterozigosidade, amplificação do gene, ganho ou perda de cromossomos), crescimento (perda do controle do ciclo celular, fatores de crescimento, neovascularização, resistência a apoptose (inativação das vias de morte celular, ganho de fatores antiapoptóticos e de sobrevivência), invasão e metástase (mobilidade celular, adesão celular, enzimas proteolíticas), e escapar da vigilância imunológica (perda ou ganho de reguladores imunológicos). Todos estes fatores distinguem melanócitos neoplásicos dos melanócitos normais (Carlson et al., 2005). 
Segundo Palmieri et al. (2009), várias vias moleculares tem sido envolvidas na alteração clonal primária dos melanócitos, incluindo aquelas que induzem a proliferação celular (via proliferativa) ou a superação da senescência celular (via de senescência).

Dentre estas vias, destaca-se a via proliferativa a via do MAPK ("mitogen activated protein kinase") (incluindo a cascata de proteínas do NRAS, BRAF, MEK1/2 e ERK1/2), a principal cascata de sinalização envolvida no controle do crescimento celular, proliferação e migração, tem sido reportada a desempenhar um papel importante em ambos desenvolvimento e progressão do melanoma (o aumento da atividade das proteínas ERK1/2, que tem sido encontrados ativados constitutivamente em melanoma, principalmente como consequência de mutações dos componentes "upstream" da via) e parece ser implicado no crescimento celular do melanoma rápido, reforço na sobrevivência da célula e resistência a apoptose.

\subsubsection{VIA DA SINALIZAÇÃO DA MAPK (“mitogen activated protein kinase")}

Em condições fisiológicas a via de sinalização MAPK regula o crescimento celular, sobrevivência e migração através de transdução de sinais proliferativos gerados pelos receptores da superfície celular e componentes de sinalização citoplasmática para dentro do núcleo através de eventos de fosforilação (Fecher et al., 2008; Halilovic e Solic, 2008; Smalley, 2010). A desregulação desta via através da 
ativação constitutiva é um evento frequente em neoplasias humanas (Fecher et al., 2008).

A sinalização da MAPK inicia-se pelos sinais extracelulares que se ligam nos receptores de tirosina quinases (RTK) e subseqüente ativação do RAS, uma GTPase ligada à membrana (Fecher et al., 2008; Smalley, 2010). O RAS ativa a proteína RAF, uma serina/treonina proteína quinase, que fosforilam e ativam as MEK1 e MEK2 (MAP quinase - quinases reguladas por sinais extracelulares), que por sua vez fosforilam e ativam ERK1 e ERK2 (quinases reguladas por sinais extracelulares). O ERK ativado regula expressão gênica pela fosforilação de inúmeros fatores de transcrição nuclear ou indiretamente atingindo moléculas sinalizadoras intracelulares (Fecher et al., 2008; Omholt et al., 2008; Smalley, 2010). Esta via é importante em diversos processos celulares cruciais, como proliferação e diferenciação (Saldanha et al., 2006; Smalley, 2010) (Figura 1). 
FIGURA 1: Representação esquemática da via de sinalização da MAPK

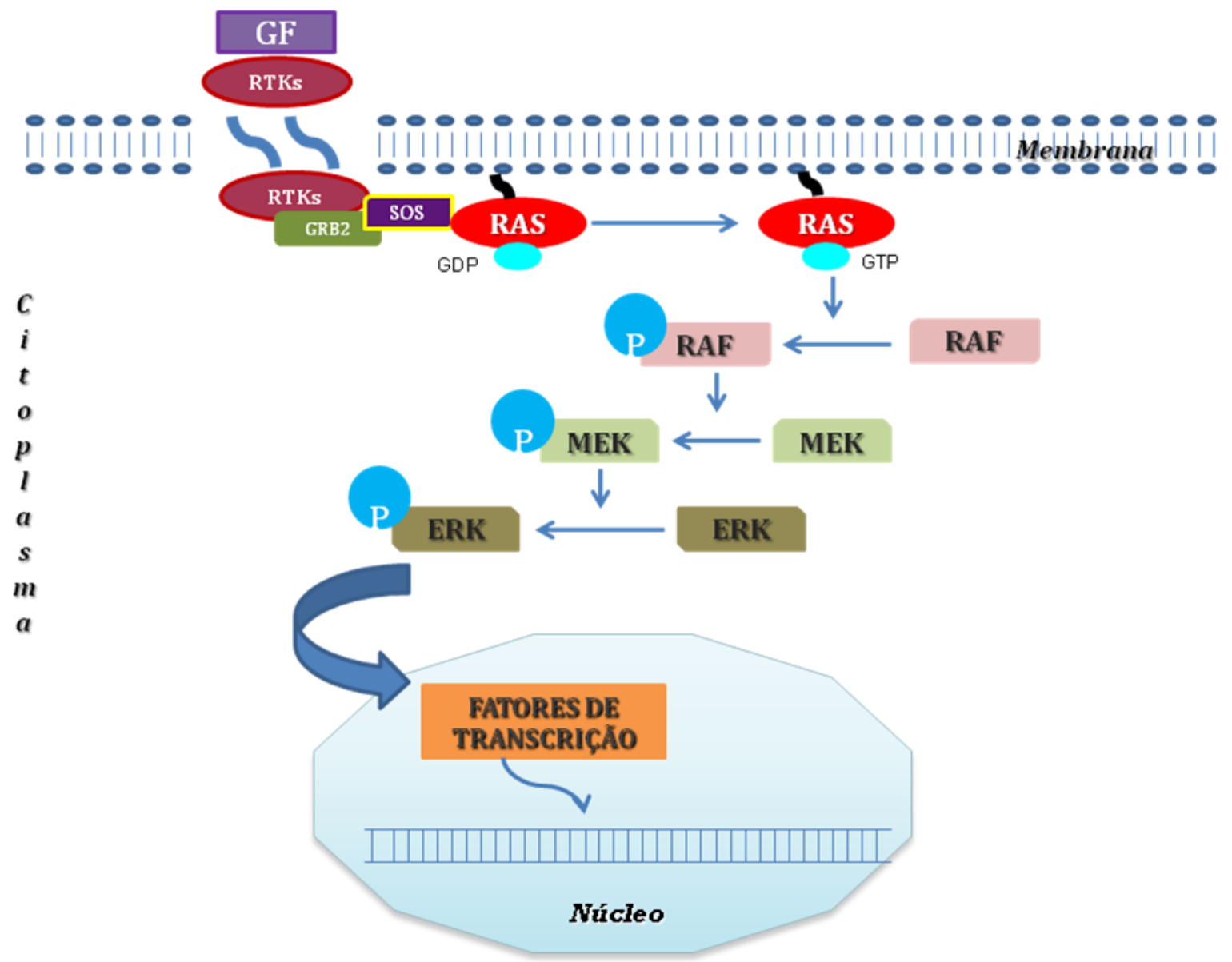




\subsubsection{Família RAS}

Historicamente, o homólogo do vírus RAS (rat sarcoma) foi o primeiro oncogene descrito em câncer humano (Jarell et al., 2007). As proteínas RAS são pequenas proteínas-G (21 quilodaltons) - ativas com GTP ligado e inativas com GDP ligado. Embora o GTP possa se hidrolisar, existe uma classe de enzimas denominadas GAPs (proteínas ativadoras de GTPase) que facilita essa hidrólise e atividade RAS terminado (Jarell et al., 2007; Ghosh e Chin, 2009).

Os genes RAS são os genes mais frequentemente mutados em neoplasias humanas, porém diferentes neoplasias mostram frequências e espectro de mutações diferentes em NRAS, HRAS e KRAS, membros da superfamília RAS (Haluska et al., 2006; Jarell et al., 2007).

O primeiro gene encontrado especificamente alterado em melanomas cutâneos foi o NRAS (homólogo do oncogene viral RAS do neuroblastoma), cuja mutação ocorre em 15 a 25\% das linhagens celulares de melanoma e tumores primários (Dahl e Guldberg, 2007). Foram encontradas mutações em NRAS em 56\% nevo congênito, 33\% de tumores primários e 26\% dos tumores metastáticos (Chin et al., 2006; Ghosh e Chin, 2009). No estudo de van't Veer et al. (1989), mutação de NRAS foi detectada em $20 \%$ dos melanomas primários, maior parte das lesões com mutação RAS forem em sítios expostos ao sol, sugerindo que a irradiação ultravioleta causou a mutação. 
As mutações no RAS são comuns em cânceres de cólon e pancreático, bem como em outras neoplasias humanas, mas estão presentes em $15 \%$ dos melanomas, sendo o NRAS a isoforma mais comumente mutada em melanoma, com incidência relacionada ao subtipo histológico e sítios primários. Semelhante à incidência dos melanomas cutâneos, as mutações de NRAS estão presentes em apenas $14 \%$ de melanomas não-cutâneos (incluindo cérebro, uveal) (Fecher et al., 2008). Segundo a literatura, mutações do NRAS são raros em nevos displásicos, ativação do HRAS é comumente associado ao nevo Spitz, enquanto que mutações do KRAS não tem sido descrito em lesões melanocíticas humanas (Chin et al., 2006; Ghosh e Chin, 2009).

Melanomas humanos carregam mutações quase exclusivamente no NRAS, aproximadamente, $80-90 \%$ delas localizadas no códon 61 , sendo HRAS e KRAS menos mutados (Edlundh-Rose et al., 2006; Haluska et al., 2006; Dahl e Guldberg, 2007; Jarell et al., 2007; Jovanovic et al., 2008).

\subsubsection{Família RAF}

A família RAF de proteínas quinases serina/treonina consiste de três membros: ARAF; BRAF; CRAF, os quais diferem em suas distribuições no tecido e os quais tem sobreposição bem como funções reguladoras únicas (Houben et al., 2004; Dahl e Guldberg, 2007; Dhomen e Marais, 2007; Jarell et al., 2007; Palmieri et al., 2007; Fecher et. al., 2008; Ghosh e Chin, 2009). As moléculas de sinalização da quinase RAF 
tem sido envolvida em uma variedade de processos celulares, como crescimento, proliferação, sobrevivência, diferenciação e transformação (Jarell et al., 2007).

Desde a descoberta através do programa de sequenciamento amplo do genoma do câncer (exemplo: Sanger Institute's Cancer Genome Project), mutações do BRAF foram encontradas em uma variedade de tumores com a maior incidência em melanoma (variando de 27 a 70\%), seguido pelo carcinoma papilífero da tireóide, carcinomas do cólon e de ovário (Chin et al., 2006; Dahl e Guldberg, 2007; Jarell et al., 2007). Segundo Haluska et al., 2006, a mais importante mutação já descoberta em melanomas ocorre no BRAF. As mutações em ARAF e CRAF são raras ou nunca encontradas em cânceres humanos. O gene BRAF pode ser ativado pela substituição de um único aminoácido, muito mais frequentemente mutado em câncer humano (aproximadamente 7\% de todos os tipos) (Palmieri et al., 2007).

Enquanto as mutações em BRAF são notadas em mais de $80 \%$ dos casos de melanoma cutâneo primário, ele também está mutado na maioria dos casos de nevo melanocítico benigno e displásico, sugerindo que ele representa um dos primeiros eventos na neoplasia melanocítica (Goel et al., 2006; Dahl e Guldberg, 2007; Palmieri et al., 2007; Ghosh e Chin, 2009). Esses nevos muitas vezes permanecem em crescimento vida interrompida e raramente progride para melanoma. Isso sugere que $\mathrm{BRAF}^{\mathrm{V} 600 \mathrm{E}}$ promove um ponto de checagem para transformação maligna (Ghosh e Chin, 2009). 
Especificamente, as mutações BRAF são comuns em melanomas cutâneos decorrentes à exposição solar intermitente (59\%), como tronco e braços, comparados com somente $23 \%$ de melanomas acrais e $11 \%$ de melanomas das mucosas, porém ausente em melanoma uveal (Chin et al., 2006).

A mutação mais comum em BRAF, a qual contabiliza mais de $90 \%$ dos casos de câncer envolvendo este gene, é a substituição de acido glutâmico para valina na posição 600 (V600E), classicamente não está associada à danos induzidos por UV (Turner et al., 2005; Chin et al., 2006; Thomas, 2006; Dahl e Guldberg, 2007; Dhomen e Marais, 2007; Palmieri et al., 2007; Halilovic e Solit, 2008; Jovanovic et al., 2008; Ghosh e Chin, 2009; Smalley, 2010 ).

\subsubsection{Família ERK}

ERKs (quinase regulada por sinal extracelular) foram originalmente clonadas por Melanie Cobb e colaboradores em 1991, através de estratégias bioquímicas tradicionais. Elas compreendem uma família de proteínas quinases de 42/44 quilodaltons e ativados por fosforilação (Jarell et al., 2007), o qual regula funções celulares essenciais como proliferação, diferenciação, sobrevivência da célula e morte celular. ERK é ativado por inúmeros agentes extracelulares como fatores de crescimento, citocinas, hormônios e promotores de tumor (Mirmohammadsadegh et al., 2007). 
Em células BRAF ou NRAS tipo selvagem, a ativação do ERK é bastante baixa comparada com células mutantes e pode controlar proteínas envolvidas na aderência extracelular, motilidade celular e angiogênese. Nos melanomas, ERK pode inibir regulador do ciclo celular p27 $7^{\mathrm{kip} 1}$, pode também alterar in vitro a capacidade de invasão pela regulação da produção de metaloproteinase-1, entretanto pode também regular sobrevivência e senescência (Ghosh e Chin, 2009).

Em melanoma, a atividade do ERK tem sido aumentada nos estágios iniciais até os avançados da doença. Uma hipótese atrativa é que a mutagênese de NRAS ou BRAF, a qual ocorre anteriormente ao ERK, é primariamente responsável pela ativação do ERK observada. Entretanto, mutação de BRAF tem sido relatada em nevos e ERK ainda é ativada somente na minoria desses espécimes, outro mecanismo regulador deve ser no lugar de minimizar estimulação da MAPK indesejada. Não obstante, forte evidência apoia o argumento de que mutações do BRAF oncogênicas acontecem na superativação de MEK/ERK, o qual mantém o fenótipo transformado em melanoma maligno (Jarell et al., 2007).

A ativação de ERK1/2 foi observada em 54\% de melanomas primários por imunoistoquímica (Mirmohammadsadegh et al., 2007). Em algumas pesquisas, a ativação de ERK tem sido reportado 54-100\% dos melanomas primários, sendo que uma pesquisa mostra que $93 \%$ dos melanomas primários com mutações do BRAF no códon 600 tem ativado o ERK. Contudo, estudos anteriores também identificaram um subgrupo de melanomas sem mutação em genes NRAS e BRAF, o qual foi especulado 
que a ativação de ERK ocorre através de efetores não identificados anteriormente (Jovanovic et al., 2008).

A literatura supracitada mostra que a via MAPK é de fundamental importância na proliferação de melanócitos de melanomas cutâneos. Nos melanomas da mucosa oral não há informações sobre a participação dessa via em quaisquer estágios da doença. Com a hipótese de que essa via possa ter importantes mutações que acarretem um pior comportamento clínico e prognóstico dos melanomas da mucosa oral, nós propomos a investigar seus componentes e correlacionar os resultados obtidos com os dados clínico-evolutivos dos casos de melanoma primário da mucosa oral que foram previamente selecionados pelo nosso grupo de trabalho. 


\section{MATERIAIS E MÉTODOS}

Foram utilizados os 35 casos de melanomas orais pertencentes aos arquivos da Disciplina de Patologia Geral da Faculdade de Odontologia da Universidade de São Paulo, do Departamento de Dermatologia da Faculdade e Medicina da Universidade de São Paulo e do Departamento de Anatomia Patológica do Hospital do Câncer, Fundação Antonio Prudente, São Paulo, já organizados em forma de matriz ("tissue microarray" - TMA).

Dados dos pacientes relevantes para o estudo foram analisados quando presentes nos prontuários: idade, sexo, raça, localização da lesão, e, quando possível, modalidade de tratamento e evolução.

Cortes histológicos dos tumores corados pela técnica da hematoxilina e eosina (H/E) foram analisadas para o estudo morfológico dos padrões arquiteturais e celulares dos casos incluídos no estudo. Todos os casos encontrados no arquivo foram incluídos no estudo, independente de seus padrões morfológicos ou extensão/profundidade, devido à raridade da lesão e a existência de poucos casos disponíveis para o estudo. 
ESQUEMA: ESTUDO DA VIA DE SINALIZAÇÃO MAPK NOS MELANOMAS PRIMÁRIOS DA MUCOSA ORAL

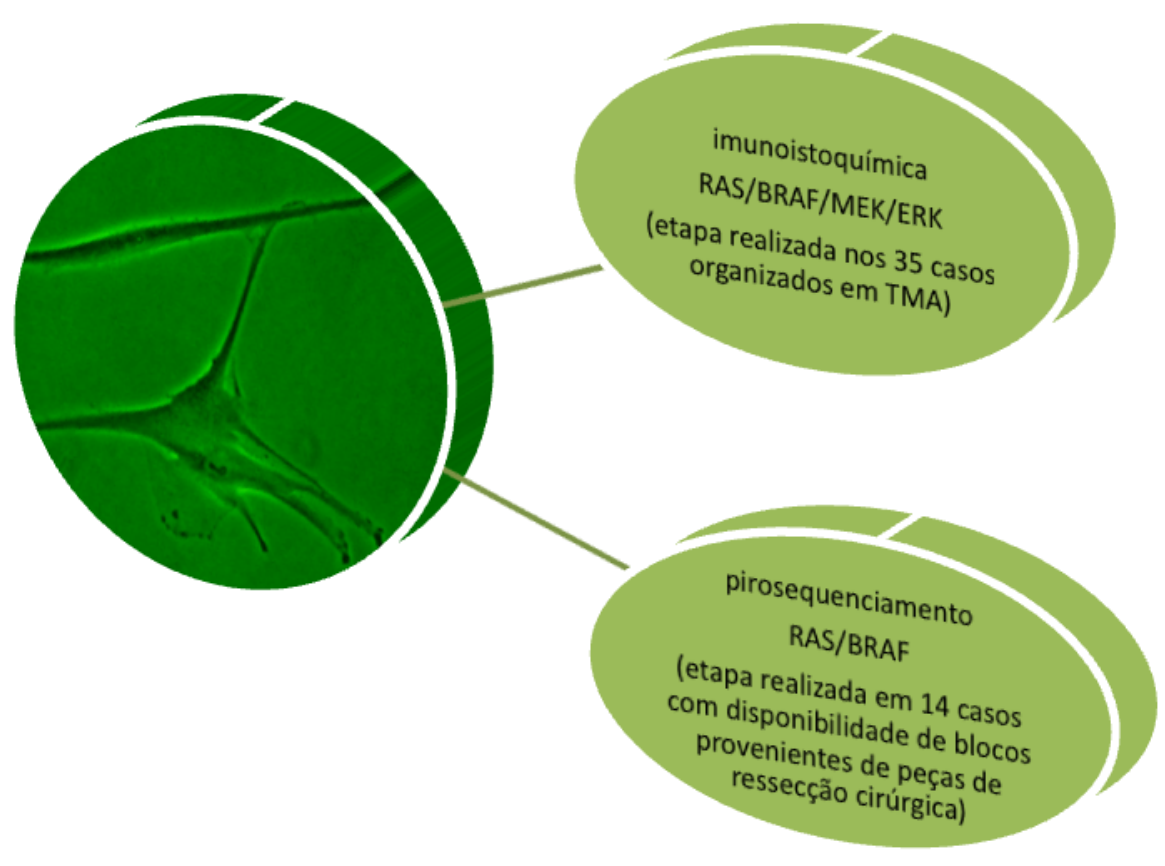




\subsection{Etapa in situ de estudo da via MAPK em melanomas primários da mucosa oral}

\subsubsection{ANÁLISE IMUNOISTOQUÍMICA DOS TMAs DE MELANOMAS ORAIS}

Cortes seriados de $4 \mu \mathrm{m}$ dos espécimes selecionados foram utilizados para a análise imunoistoquímica.

As reações imunoistoquímicas foram realizadas por meio da técnica da fosfatase alcalina, cujo protocolo é descrito a seguir:

Os cortes de $4 \mu \mathrm{m}$ foram desparafinados em dois banhos de xilol: o primeiro a $60^{\circ} \mathrm{C}$ por 30 minutos e o segundo à temperatura ambiente por 20 minutos. A seguir os cortes foram re-hidratados em cadeia descendente de etanol (100\%, 95\%, 85\%, respectivamente) e imersos em solução de hidróxido de amônia a 10\% durante 10 minutos para a remoção de pigmentos formólicos.

Na recuperação dos epítopos antigênicos foi utilizada tampão de ácido cítrico pH 6,0 aquecido em panela de pressão durante 25 minutos (Tabela 1).

Repetida a lavagem com água corrente e água destilada, os cortes foram imersos duas vezes em solução de TRIS pH 7,4, por dois minutos cada. Em seguida, os cortes foram incubados com solução de 1\% BSA (Sigma), 5\% SFB (Cultilab) em TRIS, pH 7,4, por 60 minutos, a fim de se bloquear reações do soro primário com proteínas nãoespecíficas teciduais. 
Em seguida, os cortes foram incubados com o soro primário diluído em solução de 1\% BSA (Sigma) em TRIS pH 7,4. Informações sobre os anticorpos e etapas específicas do protocolo são descritas na Quadro 1. A incubação com todos os soros primários foi realizada "overnight".

Os procedimentos posteriores foram sempre precedidos de duas lavagens em solução de Tween 20 a 1\% em TRIS pH 7,4, durante 5 minutos cada.

Após a incubação com o soro primário, os espécimes foram incubados com os dois reagentes En Vision fosfatase alcalina (Dako Cytomation) por 30 minutos cada reagente.

Para a reação de revelação, os espécimes foram incubados com o revelador permanente "Permanent Red" (Dako Cytomation), por 3 a 10 minutos, que evidencia a reação por meio de coloração vermelha.

Os cortes foram então lavados em tampão TRIS pH 7,4; água corrente e água destilada e contra-corados com hematoxilina de Carazzi por 5 minutos.

Posteriormente, os cortes foram desidratados em cadeia ascendente de etanóis, diafanizados em três banhos de xilol, e montados em resina Entellan para o exame ao microscópio de luz.

Controles negativos das reações supracitadas foram realizados por meio da incubação de espécimes com soro não-imune, que substituiu o anticorpo primário. Controles positivos pertinentes foram incluídos de acordo com as especificações de cada anticorpo (Quadro 3). 
As reações foram analisadas em microscópio óptico e os dados estudados de forma qualitativa e semi-quantitativa por dois pesquisadores.

Os dados foram fotografados com equipamento fotográfico digital acoplado a microscópio óptico convencional.

\begin{tabular}{|c|c|c|c|c|}
\hline \multicolumn{6}{|c|}{ Quadro 3: ANTICORPOS PRIMÁRIOS, PROCEDÊNCIA, TITULO E DETALHES DO PROTOCOLO } \\
\hline $\begin{array}{c}\text { SORO } \\
\text { PRIMÁRIO }\end{array}$ & $\begin{array}{c}\text { PROCEDÊNCIA } \\
\text { E CLONE }\end{array}$ & TíTULO & $\begin{array}{c}\text { CONTROLE } \\
\text { POSITIVO }\end{array}$ & $\begin{array}{c}\text { RECUPERAÇÃo } \\
\text { ANTIGÊNICA }\end{array}$ \\
\hline RAS & $\begin{array}{c}\text { Abcam } \\
\text { F132-62 }\end{array}$ & $1: 10$ & $\begin{array}{c}\text { Pele } \\
\text { normal }\end{array}$ & $\begin{array}{c}\text { Ácido cítrico/ } \\
\text { Panela de Pressão }\end{array}$ \\
\hline BRAF & $\begin{array}{c}\text { Abcam } \\
1 \mathrm{H} 12\end{array}$ & $1: 500$ & $\begin{array}{c}\text { Pele } \\
\text { normal }\end{array}$ & $\begin{array}{c}\text { Ácido cítrico/ } \\
\text { Panela de Pressão }\end{array}$ \\
\hline MEK1 & $\begin{array}{c}\text { Abcam } \\
\text { E342 }\end{array}$ & $1: 100$ & $\begin{array}{c}\text { Pele } \\
\text { normal }\end{array}$ & $\begin{array}{c}\text { Ácido cítrico/ } \\
\text { Panela de Pressão }\end{array}$ \\
\hline MEK2 & $\begin{array}{c}\text { Abcam } \\
\text { Y78 }\end{array}$ & $1: 150$ & $\begin{array}{c}\text { Pele } \\
\text { normal }\end{array}$ & $\begin{array}{c}\text { Ácido cítrico/ } \\
\text { Panela de Pressão }\end{array}$ \\
\hline ERK1 & $\begin{array}{c}\text { Abcam } \\
\text { ab57444 }\end{array}$ & $1: 300$ & $\begin{array}{c}\text { Pele } \\
\text { normal }\end{array}$ & $\begin{array}{c}\text { Ácido cítrico/ } \\
\text { Panela de Pressão }\end{array}$ \\
\hline ERK2 & $\begin{array}{c}\text { Abcam } \\
5 E 8 E 1\end{array}$ & $1: 500$ & $\begin{array}{c}\text { Pele } \\
\text { normal }\end{array}$ & $\begin{array}{c}\text { Ácido cítrico/ } \\
\text { Panela de Pressão }\end{array}$ \\
\hline
\end{tabular}




\subsection{Etapa de estudo molecular da via MAPK em melanomas primários da mucosa} oral (Análise molecular de melanomas orais pelo pirosequenciamento)

\subsubsection{Extração de DNA}

As amostras de melanomas da mucosa oral incluídas em blocos de parafina foram cortadas em micrótomo para a confecção 6 ou mais lâminas histológicas, com espessura de $5 \mu \mathrm{m}$. Uma lâmina foi preparada através da técnica histoquímica Hematoxilina e Eosina (HE) e analisada por um patologista que delimitou a região do tumor a ser microdissecada. O restante das lâminas foi utilizado para a microdissecção, através da raspagem (scrape) do tecido, obtenção de material desparafinado contendo células tumorais para a extração do seu DNA.

As lâminas selecionadas foram desparafinadas da seguinte maneira: as lâminas contendo o tecido foram submetidas ao aquecimento em estufa a $60^{\circ} \mathrm{C}$ por 30 minutos, posteriormente com dois banhos de xilol à temperatura ambiente de 5 minutos cada, seguida de dois banhos em álcool absoluto à temperatura ambiente de 2 minutos cada. Todo material já com a parafina removida ficou secando em temperatura ambiente durante 5 minutos. $O$ tecido contendo as células tumorais foi raspado das lâminas com um bisturi estéril e todo material raspado foi acondicionado em microtubo de 1,5 ml. Após realizado esta etapa, o tubo foi centrifugado, para que o material raspado se concentrasse no fundo dos tubo. 
Todo o material a ser extraído contido no microtubo foi submetido à etapa de digestão enzimática: incubação com $20 \mu \mathrm{l}$ de Proteinase $\mathrm{K}$ e $90 \mu \mathrm{l}$ de tampão ATL, ambos oriundos do QIAamp DNA Mini Kit (Qiagen, Valencia, CA), em um agitador de tubos a $57^{\circ} \mathrm{C}$ e $450 \mathrm{rpm}$ durante 12 horas.

Após a etapa da digestão enzimática, foi iniciada a etapa de extração do DNA com a neutralização do conteúdo dos tubos, adicionando neles $200 \mu \mathrm{l}$ de tampão AL e $1 \mu$ de RNA carrier (substância que separa o RNA do DNA), ambos providos do QIAamp DNA Mini Kit (Qiagen, Valencia, CA). Em seguida, foram adicionados $200 \mu$ l de etanol absoluto e incubados a temperatura ambiente durante 5 minutos, antes de prosseguir para próxima etapa.

A etapa seguinte consiste na separação do DNA genômico. Após a incubação descrita anteriormente, todo conteúdo do microtubo foi transferido para coluna de filtragem acoplada a tubos de coleta e centrifugado a $8000 \mathrm{rpm}$ por 1 minuto. Transfere-se a coluna para um tubo coletor novo, e foi adicionado $500 \mu$ le tampão AW1, seguido de centrifugação a 8000 rpm por 1 minuto. Após este procedimento, transfere-se a coluna para novo tudo coletor, e será adicionado $500 \mu$ de tampão AW2 e novamente centrifugado a $8000 \mathrm{rpm}$ por 1 minuto. Todo material utilizado nesta etapa, também foram fornecidos no QIAamp DNA Mini Kit (Qiagen, Valencia, CA).

Para uma melhor eficiência, a coluna foi transferida para um tubo coletor novo, foi adicionado $500 \mu \mathrm{l}$ de álcool a $70 \%$ e centrifugação a 8000 rpm por 1 minuto. Para 
secar o conteúdo, descarta-se o álcool contido no tubo coletor, e centrifugou-se as colunas a 14.000 rpm por 3 minutos.

Para finalizar, a obtenção do material genômico, transfere-se a coluna de filtragem para microtubo de 1,5 $\mu \mathrm{l}$, adicionou-se $50 \mu \mathrm{l}$ de água Milliq autoclavada no centro da membrana da coluna, incuba-se em temperatura ambiente por 1 minuto e centrifuga-se a coluna posicionada no microtubo em $14.000 \mathrm{rpm}$ por 1 minuto e meio.

\subsubsection{Quantificação de DNA}

O DNA extraído foi quantificado no Nanodrop (Nanodrop 1000 - Thermo Scientific) em comprimento de onda $260 / 280$, enquanto a qualidade e integridade do DNA, foi analisado por eletroforese em gel de agarose a $1 \%$ e corados com Sybr Safer (Invitrogen, Carlsbad, CA).

4.2.3 Amplificação por reação em cadeia da polimerase (PCR)

Para a confirmação da qualidade e integridade do material extraído, foi realizada a amplificação por reação de PCR utilizando um gene constitutivo $\beta$-actina, já padronizada e analisado por eletroforese em gel de agarose a $2 \%$ e corados com Sybr Safer (Invitrogen, Carlsbad, CA) para confirmar o sucesso da amplificação.

A região do exon 15 do gene $B R A F$, incluindo o sítio de mutação no códon 600; 
região dos códons 12 e 13 do gene NRAS e a região dos códons 12 e 13 do gene KRAS foram amplificados separadamente por PCR, utilizando-se iniciadores (primers) PyroMark Q96 BRAF (96); NRAS Pyro Kit (24) e PyroMark Q96 KRAS (96) (QIAGEN, Valencia, CA). Os primers anti-senso (reverse) eram biotinilados para facilitar o isolamento da molécula simples fita de DNA para a reação de pirosequenciamento. Cada reação de PCR continha 10 ng de DNA genômico, 10 pmol de cada primer, $1 X$ tampão de PCR, 1,5 mM de $\mathrm{MgCl}_{2}, 0,2 \mathrm{mM}$ de cada deoxinucleotídeo trifosfatado (DNTP), 1,25 U de Taq Platinun (Invitrogen, Carlsbad, CA) em volume final de $50 \mu \mathrm{l}$. A amplificação foi realizada com o seguinte ciclo: $95^{\circ} \mathrm{C}$ por 15 minutos para a denaturação, 45 ciclos de $95^{\circ} \mathrm{C}$ por 20 segundos, $58^{\circ} \mathrm{C}$ por 20 segundos, $72^{\circ} \mathrm{C}$ por 20 segundos e extensão final de $72^{\circ} \mathrm{C}$ por 5 minutos. A PCR foi realizada em termociclador PCR Eppendorf Mastercycler Gradient (Brinkman Instruments, Westbury, NY).

O produto amplificado por PCR foi submetido à eletroforese em gel de agarose 2\% e corados com Sybr Safer (Invitrogen, Carlsbad, CA) para confirmar o sucesso da amplificação.

\subsubsection{Pirosequenciamento}

A análise de mutação dos genes BRAF, NRAS e KRAS pode ser realizada por várias metodologias, mas o pirosequenciamento tem sido considerado uma das técnicas mais sensíveis e rápidas para esta finalidade. O pirosequenciamento é uma abordagem baseada no monitoramento em tempo real da síntese do DNA. A reação de 
pirosequenciamento é catalisada por 4 enzimas: DNA polimerase, ATP sulfurilase, luciferase e apirase. Após o anelamento do iniciador, a cada nucleotídeo incorporado, pela atividade da DNA polimerase, ocorre a liberação de fosfato inorgânico (PPi), substrato da ATP sulfurilase para a produção de ATP. Este por sua vez reage com a luciferase produzindo luz, cuja intensidade é proporcional à quantidade nucleotídeos incorporados. A apirase degrada os nucleotídeos não incorporados e o excesso de ATP.

A preparação do DNA fita simples para o Pirosequenciamento foi realizada usando o PSQ Vaccuun Prep Tool (Biotage, Uppsala, Sweden) de acordo com as instruções do fabricante. $25 \mu$ do produto de PCR foi imobilizado utilizando-se esferas de agarose marcadas com estreptoavidina (Streptavidin Sepharose High Performace, GE Healthcare, Piscataway, NJ). Em uma placa de 96 poços (Millipore, Bedford, MA) foram transferidos $25 \mu \mathrm{l}$ do produto amplificado por PCR e adiconado $55 \mu \mathrm{l}$ da mistura de beads de sefarose ( $3 \mu$ l de beads de sefarose, $40 \mu$ l de tampão de ligação e $15 \mu$ l de água deionizada) em cada poço. A placa foi agitada por 15 minutos a 1350 rpm e em seguida foi levada à bomba de vácuo (Vaccuun Prep Toll), onde o produto de PCR ligado a beads foi precipitado com álcool 70\%, desnaturado em tampão de desnaturação e lavado em tampão de lavagem (Biotage, Uppsala, Sweden)

Em seguida os produtos purificados foram incubados com $0,4 \mu \mathrm{mol} / \mathrm{L}$ de primers de sequenciamento dos genes BRAF, NRAS e KRAS, previamente diluídos em $38.6 \mu \mathrm{l}$ de tampão de anelamento, a $80^{\circ} \mathrm{C}$ por 2 minutos em placa de sequenciamento (PSQ 96 plate), 5 minutos na placa aquecedora e 5 minutos a temperatura ambiente. 
Os produtos purificados ligado ao primers de seqüência foram transferidos a base do PSQ HS 96 A Pyrosequencer (Biotage, Uppsala, Sweden), onde o sequenciamento em tempo real do códon 600 do gene BRAF, dos códons 12 e 13 do gene NRAS e dos códons 12 e 13 do gene KRAS foi realizado usando PyroGold reagents (Biotage, Uppsala, Sweden). A enzima, o substrato e os nucleotídeos A,T,C e G, foram dispensados um de cada vez em cada poço, na ordem determinada pelo aparelho. Após ser dispensado o nucleotídeo foi incorporado à fita simples de DNA e liberou um Pi (pirofosfato), este Pi se ligará ao ADP, formando ATP, que por sua vez ao ser degradado pela luciferina liberou um pico de luz que foi capturado pelo aparelho e convertido em pico no pirograma (gráfico), o sinal fluorescente foi gerado proporcionalmente a quantidade de nucleotídeo incorporado, os nucleotídeos não incorporados foram degradados para depois ser dispensado o próximo nucleotídeo.

A reação de síntese por sequenciamento da fita complementar foi realizada automaticamente pelo instrumento PyroMark MD (Qiagen) em temperatura ambiente usando reagentes PyroGold (Qiagen). O sinal emitido durante a incorporação de cada nucleotídeo foi detectado por uma câmera CCD e convertido em picos para formar um pirograma. 
4.2.5 Análise dos dados obtidos pelo pirosequenciamento:

(1) Análise da mutação do gene BRAF, códon 600 foi realizada por meio de métodos de bioinformática através do programa PSQ 96MA SNP/Pyromark ID. Foi utilizado como controle positivo das reações o DNA extraído de linhagem de células WIDr, mutante para BRAF V600E e selvagem para KRAS.

(2) Análise da mutação do gene NRAS, códons 12 e 13 foi realizada por meio de métodos de bioinformática através do programa Pyromark ${ }^{\mathrm{TM}}$ Software. Foi utilizado como controle positivo das reações DNA não metilado fornecido juntamente com o KIT comercial NRAS Pyro Kit (24) (QIAGEN, Valencia, CA).

(3) Análise de mutação do gene KRAS, códons 12 e 13, foi realizada por meio de métodos de bioinformática com utilização do programa Pyromark $^{\mathrm{TM}}$ Software. Foi utilizado como controle positivo das reações o DNA extraído de linhagem de células LS174T mutação para KRAS códon 12 e selvagem para BRAF e HCT116 mutação para KRAS códon 13. 


\section{RESULTADOS}

\subsection{RESULTADOS CLÍNICOS E HISTOPATOLÓGICOS ANALISADOS}

Seleção dos tumores

Foram selecionados 35 casos de melanoma da mucosa oral. Os casos foram provenientes dos seguintes serviços de Anatomia Patológica:

- Disciplina de Patologia Geral da Faculdade de Odontologia - FOUSP

- Divisão de Anatomia Patológica do Hospital das Clínicas - FMUSP

- Laboratório de Dermatopatologia da Divisão de Dermatologia HC-FMUSP

- Divisão de Anatomia Patológica do Hospital AC Camargo

Informações dos prontuários associadas a laudos dos exames de imagens asseguraram que todos os melanomas incluídos eram primários da mucosa oral. As informações de cada caso estão listadas nos Quadros 4 e 5, sumarizados nos Quadros 6 e 7, e representados nos Gráficos 1 a 4. Exemplos dos aspectos histopatológicos dos tumores estudados estão ilustrados nas Figuras 2 e 3.

A idade dos pacientes variou entre 9 e 91 anos e a idade média encontrada foi 61 anos ao serem diagnosticados da doença. Quanto ao gênero, encontramos 18 pacientes masculinos $(51,43 \%)$ e 17 femininos $(48,57 \%)$ e a maior prevalência dos melanomas para caucasianos (21 pacientes ou 75\%) em relação aos não-brancos (25\%) 
(5 melanodermas e 2 xantodermas). A maior parte dos pacientes $(71,42 \%)$ apresentavam lesões no palato e o aspecto histopatológico (grau III) foi observado em $80 \%$ dos espécimes. Metástase a distância foi encontrado em $60 \%$ dos casos. 
Quadro 4: Detalhes clínicos derivados da revisão dos prontuários de cada caso

\begin{tabular}{|c|c|c|c|c|c|c|c|c|}
\hline CASO & SEXO & IDADE & RAÇA & $\begin{array}{l}\text { LOCALIZAÇÃO } \\
\text { DO TUMOR }\end{array}$ & $\begin{array}{l}\text { RECORRÊNCIA } \\
\text { LOCAL }\end{array}$ & TRATAMENTO & METÁSTASE & SOBREVIDA \\
\hline 1 & $\mathrm{~F}$ & 59 & BRANCA & $\begin{array}{l}\text { PALATO DURO, } \\
\text { REBORDO } \\
\text { ALVEOLAR }\end{array}$ & $\begin{array}{l}\text { PALATO DURO, } \\
\text { REBORDO }\end{array}$ & CRIOTERAPIA & $\begin{array}{l}\text { LINFONODOS } \\
\text { CERVICAIS E } \\
\text { PULMÕES }\end{array}$ & $11 \mathrm{~m}$ \\
\hline 2 & M & 56 & NEGRA & $\begin{array}{l}\text { REBORDO } \\
\text { ALVEOLAR } \\
\text { INFERIOR }\end{array}$ & NÃO & RESSECÇÃO CIRÚRGICA & $\begin{array}{l}\text { PARÓTIDA; } \\
\text { PULMÕES }\end{array}$ & $12 m$ \\
\hline 3 & $\mathrm{~F}$ & 37 & BRANCA & $\begin{array}{l}\text { BORDA LATERAL } \\
\text { DA LÍNGUA }\end{array}$ & NÃO & QUIMIOTERAPIA & PULMÕES & ? \\
\hline 4 & M & 51 & BRANCA & $\begin{array}{l}\text { SULCO } \\
\text { VESTIBULAR } \\
\text { SUPERIOR }\end{array}$ & NÃO & QUIMIOTERAPIA & PULMÕES & $15 \mathrm{~m}$ \\
\hline 5 & M & 57 & BRANCA & $\begin{array}{l}\text { PALATO DURO, } \\
\text { REBORDO } \\
\text { ALVEOLAR }\end{array}$ & PELE & $\begin{array}{l}\text { RESSECÇÃO CIRÚRGICA+ } \\
\text { QUIMIOTERAPIA }\end{array}$ & $\begin{array}{c}\text { LINFONODOS } \\
\text { SUBMANDIBULARES } \\
\text { E PULMÕES }\end{array}$ & $25 m$ \\
\hline 6 & $\mathrm{~F}$ & 63 & ORIENTAL & PALATO DURO & NÃO & $\begin{array}{c}\text { RESSECÇÃO CIRÚRGICA+ } \\
\text { QUIMIOTERAPIA }\end{array}$ & $\begin{array}{c}\text { LINFONODOS } \\
\text { CERVICAIS E } \\
\text { SUBMANDIBULARES }\end{array}$ & $14 m$ \\
\hline 7 & $\mathrm{~F}$ & 36 & BRANCA & $\begin{array}{l}\text { PALATO DURO, } \\
\text { REBORDO } \\
\text { ALVEOLAR }\end{array}$ & PALATO & $\begin{array}{l}\text { RESSECÇÃO CIRÚRGICA+ } \\
\text { QUIMIOTERAPIA }\end{array}$ & $\begin{array}{l}\text { LINFONODOS } \\
\text { CERVICAIS }\end{array}$ & $22 m$ \\
\hline 8 & M & 60 & MULATO & $\begin{array}{l}\text { PALATO DURO, } \\
\text { MOLE E } \\
\text { ASSOALHO } \\
\text { BUCAL }\end{array}$ & $\begin{array}{l}\text { DIFUSO NA } \\
\text { MUCOSA ORAL }\end{array}$ & $\begin{array}{l}\text { RESSECÇÃO CIRÚRGICA+ } \\
\text { RADIOTERAPIA }\end{array}$ & $\mathrm{NI}$ & $40 m$ \\
\hline 9 & $\mathrm{~F}$ & 61 & BRANCA & $\begin{array}{l}\text { PALATO DURO, } \\
\text { REBORDO } \\
\text { ALVEOLAR }\end{array}$ & PALATO DURO & RESSECÇÃO CIRÚRGICA & $\begin{array}{l}\text { LINFONODOS } \\
\text { CERVICAIS E } \\
\text { PULMÕES }\end{array}$ & $?$ \\
\hline 10 & $\mathrm{~F}$ & 59 & BRANCA & $\begin{array}{l}\text { PALATO DURO, } \\
\text { REBORDO } \\
\text { ALVEOLAR } \\
\end{array}$ & NÃO & $\begin{array}{l}\text { RADIOTERAPIA+ } \\
\text { QUIMIOTERAPIA }\end{array}$ & $\begin{array}{c}\text { LINFONODOS } \\
\text { CERVICAIS E } \\
\text { SUBMANDIBULARES }\end{array}$ & $3 m$ \\
\hline 11 & M & 66 & BRANCA & $\begin{array}{l}\text { PALATO DURO, } \\
\text { REBORDO } \\
\text { ALVEOLAR }\end{array}$ & NÃO & $\begin{array}{l}\text { RESSECÇÃO CIRÚRGICA+ } \\
\text { QUIMIOTERAPIA }\end{array}$ & $\begin{array}{l}\text { LINFONODOS } \\
\text { CERVICAIS E } \\
\text { CÉREBRO }\end{array}$ & $9 m$ \\
\hline 12 & $\mathrm{~F}$ & & BRANCA & $\begin{array}{c}\text { LÁBIO SUPERIOR } \\
\text { E SULCO } \\
\text { VESTIBULAR }\end{array}$ & $\begin{array}{l}\text { REBORDO } \\
\text { ALVEOLAR }\end{array}$ & $\mathrm{NI}$ & $\mathrm{NI}$ & $30 \mathrm{~m}$ \\
\hline 13 & M & 69 & BRANCA & $\begin{array}{l}\text { PALATO DURO, } \\
\text { REBORDO } \\
\text { ALVEOLAR }\end{array}$ & NÃO & RESSECÇÃO CIRÚRGICA & $\begin{array}{l}\text { LINFONODOS } \\
\text { CERVICAIS E } \\
\text { PULMÕES }\end{array}$ & ? \\
\hline 14 & $\mathrm{~F}$ & 73 & BRANCA & $\begin{array}{l}\text { PALATO DURO, } \\
\text { REBORDO } \\
\text { ALVEOLAR }\end{array}$ & NÃO & RESSECÇÃO CIRÚRGICA & $\begin{array}{c}\text { LINFONODOS } \\
\text { SUBMENTONIANOS } \\
\text { E PULMÕES }\end{array}$ & $8 m$ \\
\hline 15 & $\mathrm{~F}$ & 87 & BRANCA & $\begin{array}{l}\text { PALATO DURO, } \\
\text { REBORDO } \\
\text { ALVEOLAR, } \\
\text { MUCOSA JUGAL }\end{array}$ & NÃO & RESSECÇÃO CIRÚRGICA & $\begin{array}{c}\text { LINFONODOS } \\
\text { SUBMENTONIANOS } \\
\text { E PULMÕES }\end{array}$ & $49 m$ \\
\hline 16 & $\mathrm{~F}$ & 56 & BRANCA & MANDÍBULA & $\mathrm{NI}$ & $\mathrm{NI}$ & $\begin{array}{l}\text { LINFONODOS } \\
\text { CERVICAIS; FOSSA } \\
\text { INFRATEMPORAL }\end{array}$ & ? \\
\hline
\end{tabular}




\begin{tabular}{|c|c|c|c|c|c|c|c|c|}
\hline CASO & SEXO & IDADE & RAÇA & $\begin{array}{l}\text { LOCALIZAÇÃO } \\
\text { DO TUMOR }\end{array}$ & $\begin{array}{l}\text { RECORRÊNCIA } \\
\text { LOCAL }\end{array}$ & TRATAMENTO & METÁSTASE & SOBREVIDA \\
\hline 17 & M & 51 & BRANCA & PALATO DURO & NÃO & $\begin{array}{l}\text { RESSECÇÃO CIRÚRGICA+ } \\
\text { QUIMIOTERAPIA }\end{array}$ & $\begin{array}{l}\text { LINFONODOS } \\
\text { CERVICAIS }\end{array}$ & $27 m$ \\
\hline 18 & M & 61 & $\mathrm{NI}$ & $\begin{array}{l}\text { SOALHO DA } \\
\text { BOCA, MUOCSA } \\
\text { JUGAL, BORDA } \\
\text { LATERAL DA } \\
\text { LÍNGUA E } \\
\text { PALATO MOLE }\end{array}$ & NÃO & RESSECÇÃO CIRÚRGICA & $\begin{array}{l}\text { LINFONODOS } \\
\text { CERVICAIS }\end{array}$ & ? \\
\hline 19 & M & 57 & $\mathrm{NI}$ & $\begin{array}{l}\text { PALATO DURO, } \\
\text { REBORDO } \\
\text { ALVEOLAR }\end{array}$ & NÃO & $\begin{array}{c}\text { RESSECÇÃO } \\
\text { CIRÚRGICA+RADIOTERAPIA }\end{array}$ & NÃO & $72 m$ \\
\hline 20 & M & 78 & $\mathrm{NI}$ & $\begin{array}{l}\text { PALATO DURO, } \\
\text { REBORDO } \\
\text { ALVEOLARE } \\
\text { MUCOSA JUGAL }\end{array}$ & $\begin{array}{l}\text { DIFUSO NA } \\
\text { MUCOSA ORAL }\end{array}$ & $\begin{array}{c}\text { RESSECÇÃO CIRÚRGICA+ } \\
\text { QUIMIOTERAPIA }\end{array}$ & $\begin{array}{l}\text { LINFONODOS } \\
\text { CERVICAIS E } \\
\text { PULMÕES }\end{array}$ & ? \\
\hline 21 & M & 91 & $\mathrm{NI}$ & PALATO DURO & $\mathrm{NI}$ & $\mathrm{NI}$ & $\mathrm{NI}$ & ? \\
\hline 22 & $\mathrm{~F}$ & 46 & MULATO & $\begin{array}{c}\text { REBORDO } \\
\text { INFERIOR E } \\
\text { MUCOSA LABIAL }\end{array}$ & NÃO & RESSECÇÃO CIRÚRGICA & $\mathrm{NI}$ & $12 m$ \\
\hline 23 & $\mathrm{~F}$ & 65 & BRANCA & $\begin{array}{c}\text { PALATO DURO, E } \\
\text { MUCOSA } \\
\text { VESTIBULAR }\end{array}$ & PALATO DURO & RESSECÇÃO CIRÚRGICA & $\begin{array}{l}\text { LINFONODOS } \\
\text { CERVICAIS }\end{array}$ & $17 \mathrm{~m}$ \\
\hline 24 & M & 67 & ORIENTAL & PALATO DURO & $\mathrm{NI}$ & $\mathrm{NI}$ & $\mathrm{NI}$ & ? \\
\hline 25 & $M$ & 9 & BRANCA & PALATO DURO & PALATO DURO & $\mathrm{NI}$ & $\begin{array}{l}\text { LINFONODOS } \\
\text { CERVICAIS }\end{array}$ & $72 m$ \\
\hline 26 & M & 87 & BRANCA & $\begin{array}{c}\text { TRÍGONO } \\
\text { RETORMOLAR E } \\
\text { PALATO MOLE }\end{array}$ & $\mathrm{NI}$ & $\mathrm{NI}$ & $\begin{array}{l}\text { LINFONODOS } \\
\text { CERVICAIS }\end{array}$ & $13 m$ \\
\hline 27 & M & 47 & BRANCA & PALATO DURO & $\mathrm{NI}$ & $\mathrm{NI}$ & $\mathrm{NI}$ & ? \\
\hline 28 & $\mathrm{~F}$ & 51 & BRANCA & PALATO DURO & $\mathrm{NI}$ & $\mathrm{NI}$ & $\mathrm{NI}$ & ? \\
\hline 29 & $\mathrm{~F}$ & 46 & BRANCA & $\begin{array}{l}\text { REBORDO } \\
\text { SUPERIOR }\end{array}$ & $\mathrm{NI}$ & $\mathrm{NI}$ & $\mathrm{NI}$ & $?$ \\
\hline 30 & $\mathrm{~F}$ & 49 & $\mathrm{NI}$ & $\mathrm{NI}$ & $\mathrm{NI}$ & $\mathrm{NI}$ & $\mathrm{NI}$ & ? \\
\hline 31 & M & 63 & $\mathrm{NI}$ & MUCOSA LABIAL & $\mathrm{NI}$ & $\mathrm{NI}$ & $\mathrm{NI}$ & $?$ \\
\hline 32 & $\mathrm{~F}$ & 71 & $\mathrm{NI}$ & PALATO DURO & $\mathrm{NI}$ & $\mathrm{NI}$ & $\mathrm{NI}$ & $?$ \\
\hline 33 & $\mathrm{~F}$ & 83 & BRANCA & $\begin{array}{l}\text { PALATO DURO, } \\
\text { REBORDO } \\
\text { ALVEOLAR }\end{array}$ & PALATO DURO & CRIOTERAPIA & NÃO & $48 m$ \\
\hline 34 & $M$ & 88 & BRANCA & PALATO DURO & NÃO & CRIOTERAPIA & $\begin{array}{l}\text { LINFONODOS } \\
\text { CERVICAIS }\end{array}$ & ? \\
\hline 35 & $M$ & 78 & NEGRO & PALATO DURO & NÃO & NENHUMA & NÃO & vivo \\
\hline
\end{tabular}




\section{Quadro 5: Detalhes morfológicos dos melanomas analisados}

\begin{tabular}{|c|c|c|c|c|c|c|c|}
\hline Caso & Variação Tipo e aspecto celular arquitetural, & melanina & $\begin{array}{l}\text { Invasão } \\
\text { vascular/ } \\
\text { neural }\end{array}$ & Necrose & Regressão & Angiogênese & NÍVEL \\
\hline 1 & $\begin{array}{c}\text { Células epitélioides com citoplasma claro, núcleos } \\
\text { grandes, hipercromáticos e irregulares. Disposição } \\
\text { em tecas }\end{array}$ & ausente & $\begin{array}{l}\text { Presente/ } \\
\text { ausente }\end{array}$ & Ausente & Ausente & Presente & III \\
\hline 2 & $\begin{array}{c}\text { células pequenas e rabdóides com intenso } \\
\text { pleomorfismo, núcleos hipercromáticos. Disposição } \\
\text { em lençol }\end{array}$ & presente & $\begin{array}{l}\text { Presente/ } \\
\text { ausente }\end{array}$ & $\begin{array}{l}\text { presente } \\
\text { (extensa) }\end{array}$ & Ausente & Presente & III \\
\hline 3 & $\begin{array}{l}\text { células Poligonais com núcleos amplos, } \\
\text { hipercromáticos. Disposição em lençol }\end{array}$ & escassa & NA & $\begin{array}{l}\text { presente } \\
\text { (extensa) }\end{array}$ & NA & NA & $\mathrm{NI}$ \\
\hline 4 & $\begin{array}{l}\text { células Poligonais pequenas com núcleos } \\
\text { hipercromáticos amplos }\end{array}$ & presente & $\begin{array}{l}\text { ausente / } \\
\text { ausente }\end{array}$ & ausente & Ausente & Presente & II \\
\hline 5 & $\begin{array}{l}\text { Células poligonais/ epitelióides com intenso } \\
\text { pleomorfismo, núcleos hipercromáticos, angulados, } \\
\text { às vezes bilobulados. Disposição em lençol }\end{array}$ & intensa & $\begin{array}{l}\text { Presente/ } \\
\text { presente }\end{array}$ & presente & Ausente & Escassa & III \\
\hline 6 & $\begin{array}{c}\text { Células nevóides, com intenso pleomorfismo, núcleos } \\
\text { hipercromáticos, nucléolos evidentes. Disposição em } \\
\text { tecas }\end{array}$ & presente & $\begin{array}{l}\text { ausente / } \\
\text { ausente }\end{array}$ & $\begin{array}{l}\text { presente } \\
\text { (extensa) }\end{array}$ & $\begin{array}{l}\text { presente } \\
\text { (focal) }\end{array}$ & Presente & III \\
\hline 7 & $\begin{array}{l}\text { Células com intenso pleomorfismo, núcleos } \\
\text { hipercromáticos, formatos e tamanhos variados. } \\
\text { Disposição em lençol e tecas }\end{array}$ & escassa & $\begin{array}{l}\text { Presente/ } \\
\text { presente }\end{array}$ & $\begin{array}{l}\text { presente } \\
\text { (extensa) }\end{array}$ & Ausente & Presente & III \\
\hline 8 & $\begin{array}{l}\text { células poligonais, com núcleos amplos e nucléolos } \\
\text { proeminentes. Disposição em lençol }\end{array}$ & presente & $\begin{array}{l}\text { Ausente/ } \\
\text { ausente }\end{array}$ & ausente & Ausente & Presente & III \\
\hline 9 & $\begin{array}{l}\text { Células fusiformes/ poligonais, com núcleos } \\
\text { hipercromáticos, pleomórficos, por vezes } \\
\text { multilobulados. Disposição em tecas }\end{array}$ & presente & $\begin{array}{l}\text { Presente/ } \\
\text { presente }\end{array}$ & ausente & não detectada & Presente & III \\
\hline 10 & $\begin{array}{l}\text { células poligonais com intenso pleomorfismo e } \\
\text { núcleos hipercromáticos. Disposição em lençol }\end{array}$ & intensa & $\begin{array}{l}\text { Presente/ } \\
\text { ausente }\end{array}$ & ausente & Ausente & Presente & III \\
\hline 11 & $\begin{array}{c}\text { células poligonais, com núcleos poligonais grandes, } \\
\text { pleomórficos, hipercromáticos, mitoses freqüentes. } \\
\text { Disposição em lençol }\end{array}$ & intensa & $\begin{array}{l}\text { Presente/ } \\
\text { ausente }\end{array}$ & ausente & Ausente & Presente & III \\
\hline 12 & $\begin{array}{l}\text { células epitelióides/ nevóides, com intenso } \\
\text { pleomorfismo, núcleos hipercromáticos, formatos e } \\
\text { tamanhos variados. Disposição em lençol }\end{array}$ & escassa & $\begin{array}{l}\text { Ausente/ } \\
\text { ausente }\end{array}$ & presente & não detectada & Presente & III \\
\hline 13 & $\begin{array}{l}\text { células fusiformes, pleomórficas, intenso número de } \\
\text { mitoses, núcleos de tamanhos e formatos variados, } \\
\text { nucléolos proeminentes. Disposição em lençol }\end{array}$ & escassa & $\begin{array}{l}\text { Presente/ } \\
\text { ausente }\end{array}$ & presente & Ausente & Presente & III \\
\hline 14 & $\begin{array}{c}\text { Células epitelióides, com intenso pleomorfismo, } \\
\text { núcleos hipercromáticos, formatos e tamanhos } \\
\text { variados. Disposição em lençol }\end{array}$ & Intensa & $\begin{array}{l}\text { Presente/ } \\
\text { presente }\end{array}$ & presente & não detectada & Presente & II \\
\hline 15 & $\begin{array}{c}\text { Células epitelióides, de morfologia não avaliável } \\
\text { devido a intensa deposição de melanina. Disposição } \\
\text { em tecas }\end{array}$ & Intensa & $\begin{array}{l}\text { Ausente/ } \\
\text { ausente }\end{array}$ & ausente & Ausente & $\begin{array}{l}\text { Presente } \\
\text { (intensa) }\end{array}$ & III \\
\hline 16 & $\begin{array}{c}\text { células nevóides,com intenso pleomorfismo, núcleos } \\
\text { hipercromáticos berrantes e núcleos bizarros. } \\
\text { Disposição em lençol }\end{array}$ & $\begin{array}{l}\text { escassa } \\
\text { (focal) }\end{array}$ & $\begin{array}{l}\text { Presente/ } \\
\text { ausente }\end{array}$ & ausente & NA & Presente & III \\
\hline 17 & $\begin{array}{l}\text { células fusiformes pequenas, com intenso } \\
\text { pleomorfismo, núcleos grandes, hipercromáticos, } \\
\text { com formatos e tamanhos variados, numerosas } \\
\text { mitoses, nucléolos proeminentes. Disposição em } \\
\text { lençol }\end{array}$ & Intensa & $\begin{array}{l}\text { Presente/ } \\
\text { presente }\end{array}$ & $\begin{array}{l}\text { presente } \\
\text { (extensa) }\end{array}$ & Ausente & Presente & III \\
\hline
\end{tabular}




\begin{tabular}{|c|c|c|c|c|c|c|c|}
\hline Caso & Variação Tipo e aspecto celular arquitetural, & melanina & $\begin{array}{l}\text { Invasão } \\
\text { vascular/ } \\
\text { neural }\end{array}$ & necrose & Regressão & Angiogênese & Nível \\
\hline 18 & $\begin{array}{l}\text { Células epiteliais e fusiformes, com intenso } \\
\text { pleomorfismo, hipercromasia nuclear, nucléolos } \\
\text { proeminentes, núcleos vazados. Disposição em lençol }\end{array}$ & Intensa & $\begin{array}{l}\text { Presente/ } \\
\text { ausente }\end{array}$ & presente & Ausente & Presente & III \\
\hline 19 & $\begin{array}{c}\text { Células epiteliólides com intenso } \\
\text { pleomorfismo,mitoses frequentes, núcleos } \\
\text { hipercromáticos, citoplasma eosinofílico amplo e } \\
\text { nucléolos proeminentes. Disposição em lençol e tecas }\end{array}$ & Intensa & $\begin{array}{l}\text { Presente/ } \\
\text { presente }\end{array}$ & ausente & Ausente & Ausente & III \\
\hline 20 & $\begin{array}{l}\text { Células epitelióides com intenso pleomorfismo, } \\
\text { núcleos irregulares, hipercromasia e, por vezes, } \\
\text { binucleação Disposição em lençol e tecas }\end{array}$ & presente & $\begin{array}{l}\text { Presente/ } \\
\text { ausente }\end{array}$ & ausente & Presente & $\begin{array}{l}\text { Presente } \\
\text { (intensa) }\end{array}$ & III \\
\hline 21 & $\begin{array}{l}\text { Células fusiformes, epitelióides e nevóides, com } \\
\text { intenso pleomorfismo, presença de mitoses bizarras, } \\
\text { núcleos grandes, hipercromáticos, com nucléolos } \\
\text { proeminentes. Disposição em lençol e tecas }\end{array}$ & escassa & $\begin{array}{l}\text { presente } \\
\text { (linfática e } \\
\text { sanguínea)/ } \\
\text { ausente }\end{array}$ & presente & Ausente & $\begin{array}{l}\text { Presente } \\
\text { (intensa) }\end{array}$ & III \\
\hline 22 & $\begin{array}{l}\text { células poligonais, com núcleos pleomórficos, de } \\
\text { difícil visualização. Disposição em lençol }\end{array}$ & intensa & $\begin{array}{l}\text { Ausente/ } \\
\text { ausente }\end{array}$ & ausente & Ausente & $\begin{array}{l}\text { Presente } \\
\text { (intensa) }\end{array}$ & II \\
\hline 23 & $\begin{array}{l}\text { células fusiformes e nevóides, com intenso } \\
\text { pleomorfismo, presença de mitoses, com núcleos } \\
\text { hipercromáticos. Disposição em lençol }\end{array}$ & presente & $\begin{array}{l}\text { Presente/ } \\
\text { presente }\end{array}$ & presente & Ausente & $\begin{array}{l}\text { Presente } \\
\text { (intensa) }\end{array}$ & III \\
\hline 24 & $\begin{array}{l}\text { Células fusiformes com núcleos hipercromáticos, } \\
\text { pleomórficos. Disposição em lençol }\end{array}$ & ausente & $\begin{array}{l}\text { Ausente/ } \\
\text { ausente }\end{array}$ & ausente & NA & Presente & III \\
\hline 25 & $\begin{array}{c}\text { células fusiformes, com núcleos pleomórficos, } \\
\text { vazados, com nucléolos proeminentes. Disposição em } \\
\text { tecas }\end{array}$ & escassa & $\begin{array}{l}\text { Presente/ } \\
\text { ausente }\end{array}$ & ausente & Ausente & $\begin{array}{l}\text { Presente } \\
\text { (discreta) }\end{array}$ & III \\
\hline 26 & $\begin{array}{l}\text { células poligonais e fusiforemes, com citoplasma } \\
\text { claro, núcleos amplos e pleomórficos. Disposição em } \\
\text { tecas }\end{array}$ & escassa & $\begin{array}{l}\text { Ausente/ } \\
\text { ausente }\end{array}$ & ausente & Ausente & Presente & III \\
\hline 27 & Células poligonais pequenas. & presente & $\begin{array}{l}\text { Ausente/ } \\
\text { ausente }\end{array}$ & ausente & Ausente & Presente & III \\
\hline 28 & $\begin{array}{c}\text { células grandes e nevóides, com citoplasma cheio de } \\
\text { melanina, núcleos pleomórficos, poligonais, } \\
\text { hipercromáticos. Disposição em tecas }\end{array}$ & presente & $\begin{array}{l}\text { Ausente/ } \\
\text { ausente }\end{array}$ & ausente & Ausente & Presente & II \\
\hline 29 & $\begin{array}{c}\text { células grandes e nevóides, com citoplasma cheio de } \\
\text { melanina, núcleos pleomórficos, poligonais, } \\
\text { hipercromáticos, Disposição em tecas }\end{array}$ & presente & $\begin{array}{l}\text { Ausente/ } \\
\text { ausente }\end{array}$ & ausente & $\begin{array}{c}\text { Não } \\
\text { detectada }\end{array}$ & Presente & III \\
\hline 30 & $\begin{array}{l}\text { células pleomórficas, de núcleos amplos, } \\
\text { multilobulados, com mitoses freqüentes. Disposição } \\
\text { em lençol }\end{array}$ & $\mathrm{NI}$ & $\mathrm{NI}$ & $\mathrm{NI}$ & $\mathrm{NI}$ & $\mathrm{NI}$ & III \\
\hline 31 & $\begin{array}{l}\text { células poligonais, com núcleos hipercromáticos, } \\
\text { intenso pleomorfismo nuclear, com mitoses } \\
\text { freqüentes. Disposição em lençol }\end{array}$ & Presente & $\begin{array}{l}\text { Presente/ } \\
\text { ausente }\end{array}$ & $\begin{array}{l}\text { presente } \\
\text { (extensa) }\end{array}$ & Ausente & $\begin{array}{l}\text { Presente } \\
\text { (intensa) }\end{array}$ & III \\
\hline 32 & $\begin{array}{l}\text { Células poligonais com núcleos amplos e nucléolos } \\
\text { proeminentes. Disposição em lençol }\end{array}$ & intensa & $\begin{array}{l}\text { Ausente/ } \\
\text { ausente }\end{array}$ & ausente & Ausente & Presente & $\|$ \\
\hline 33 & $\begin{array}{c}\text { Células fusiformes com núcleos pleomórficos } \\
\text { hipercromáticos. Mitoses presentes. Disposição em } \\
\text { lençol }\end{array}$ & intensa & $\begin{array}{l}\text { presente } \\
\text { (linfática)/ } \\
\text { presente }\end{array}$ & ausente & Ausente & Presente & III \\
\hline 34 & $\begin{array}{l}\text { células poligonais, com núcleo amplo e } \\
\text { hipercromático e mitoses freqüentes. Disposição em } \\
\text { lençol }\end{array}$ & presente & $\begin{array}{l}\text { Presente/ } \\
\text { presente }\end{array}$ & presente & NA & Presente & III \\
\hline 35 & $\begin{array}{l}\text { Células epitelióides grandes, com núcleos } \\
\text { hipercromáticos e disposição em tecas }\end{array}$ & presente & Ausente & ausente & Ausente & NA & II \\
\hline
\end{tabular}


FIGURA 2: EXEMPLOS DOS ASPECTOS HISTOPATOLÓGICOS DE MELANOMA ORAL
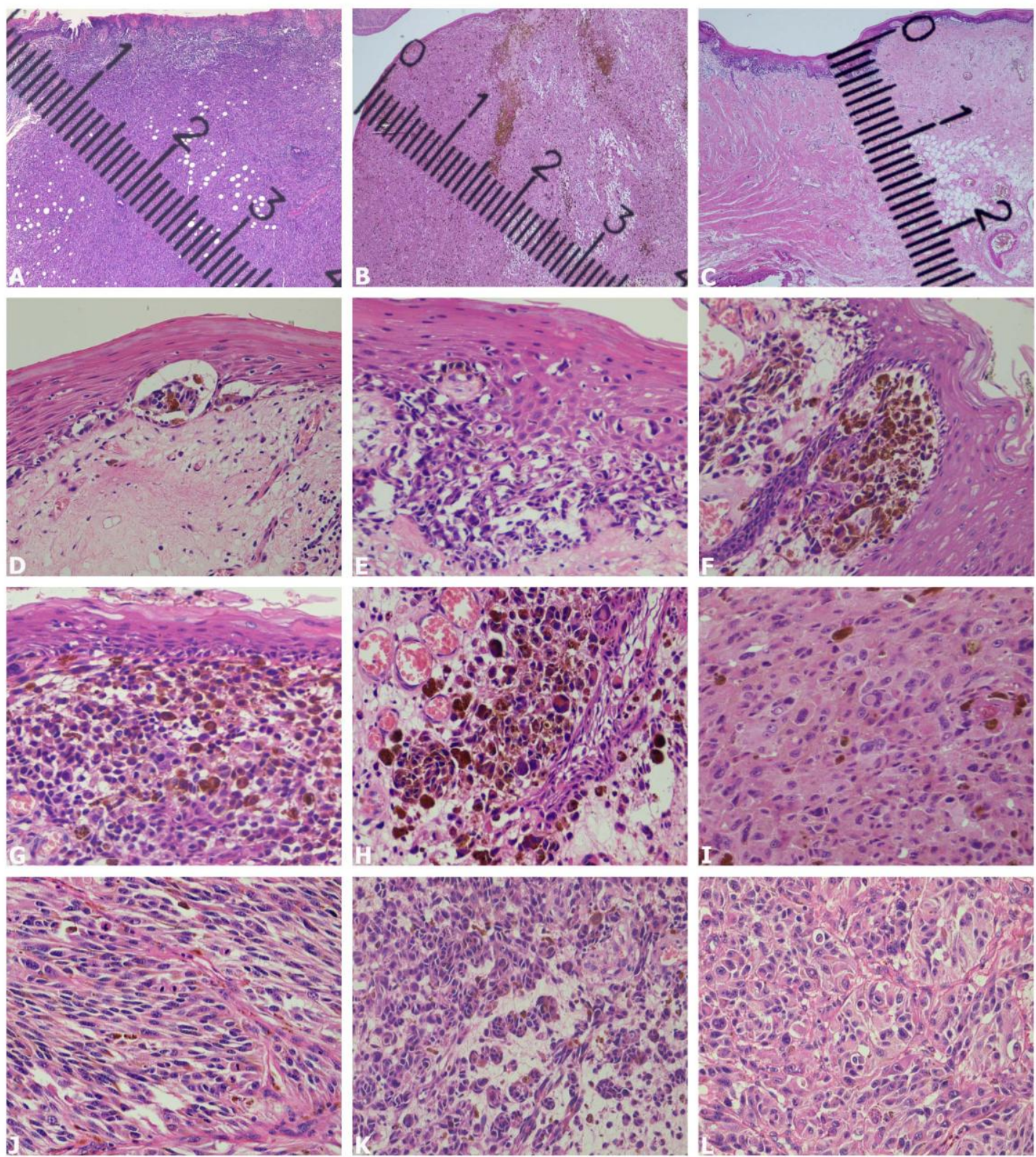

FIGURA 2 


\section{LEGENDA DA FIGURA 2: EXEMPLOS DOS ASPECTOS HISTOPATOLÓGICOS DE MELANOMA ORAL}

A, B e C: Aspectos gerais de espécimes de melanoma oral: em A e B, melanomas de nível III, com invasão de toda a faixa de lâmina própria e submucosa (medidas maiores que $3 \mathrm{~mm}$. Em C, melanoma nível II, superficialmente invasivo, medindo cerca de $0,35 \mathrm{~mm}$ (hematoxilina e eosina, aumento original $\mathrm{X} 40$ ).

D e E: Proliferação de ninhos de melanócitos neoplásicos intraepiteliais (hematoxilina e eosina, aumento original X100 e X400, respectivamente).

F: Ninhos de melanócitos neoplásicos pigmentados na lâmina própria papilar (hematoxilina e eosina, aumento original X400).

G: Lençol de melanócitos neoplásicos ocupando toda a lâmina própria. Epitélio de revestimento com atrofia e retificação dos cones epiteliais (hematoxilina e eosina, aumento original $\mathrm{X} 100)$.

H: Melanócitos neoplásicos pigmentados próximos a vasos sanguíneos neoformados na lâmina própria (hematoxilina e eosina, aumento original X400)

I, J, K e L: Aspectos morfológicos dos melanócitos neoplásicos: células com intenso pleomorfismo nuclear e hipercromasia (I), melanócitos neoplásicos fusiformes (J) e melanócitos neoplásicos pequenos organizados em ninhos pouco coesos em $\mathrm{K}$ e L (hematoxilina e eosina, aumento original X400). 
FIGURA 3: EXEMPLOS DOS ASPECTOS HISTOPATOLÓGICOS DE MELANOMA ORAL
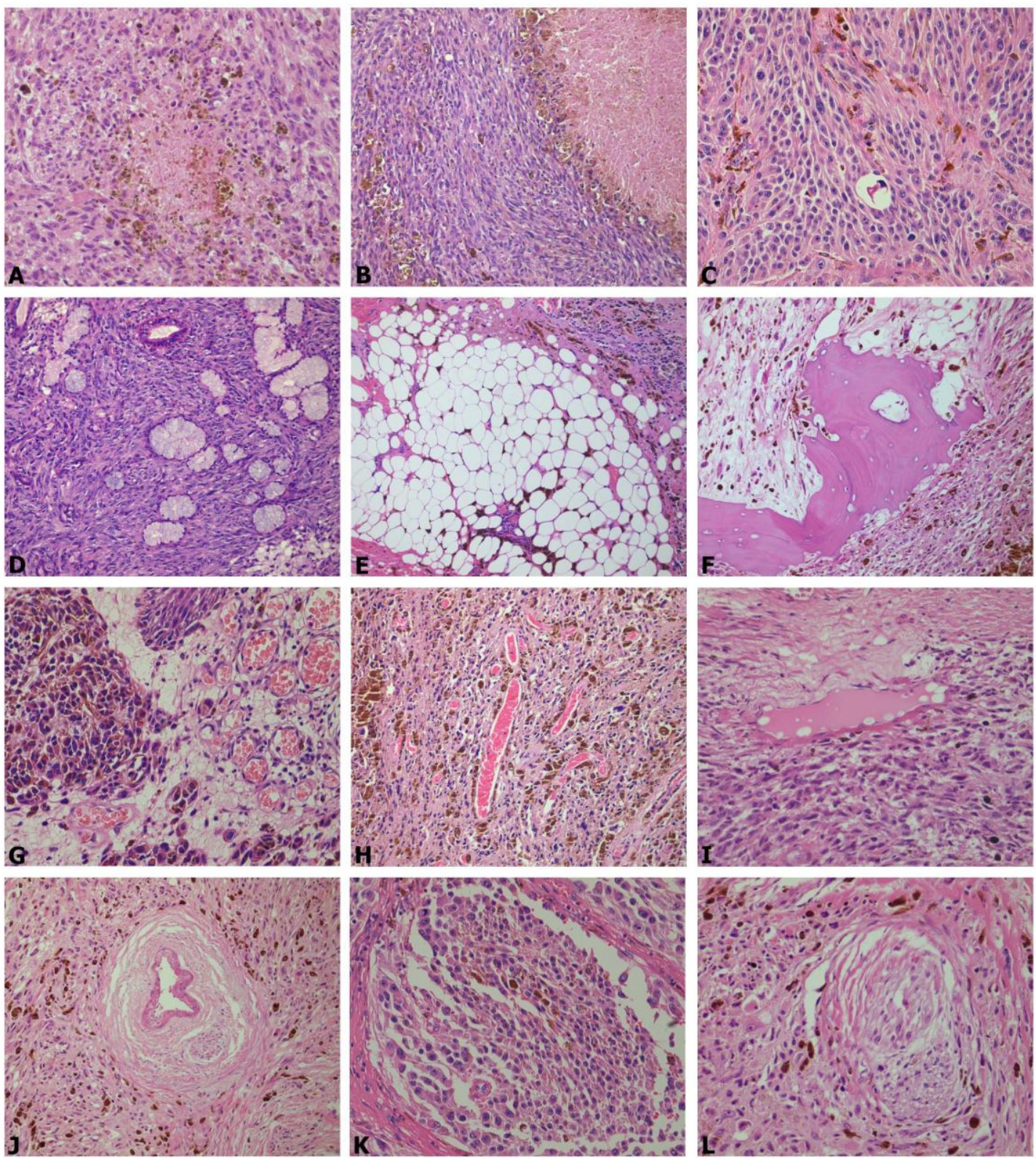

FIGURA 3 


\section{LEGENDA DA FIGURA 3: EXEMPLOS DOS ASPECTOS HISTOPATOLÓGICOS DE MELANOMA ORAL}

A e B: Focos de necrose de permeio aos melanócitos neoplásicos (hematoxilina e eosina, aumento original $\mathrm{X} 400)$.

C: Ninhos neoplásicos separado por traves fibrosas pigmentadas. Notar o intenso pleomorfismo celular (hematoxilina e eosina, aumento original X400).

D, E e F: Invasão tumoral: destruição das glândulas salivares mucosas (D), tecido adiposo (E) e osso (F) (hematoxilina e eosina, aumento original X100 em D e X400 E e F).

G - L: Relação do melanoma com vasos e nervos: angiogênese em G e H; invasão perivascular - vaso linfático (I) e vaso sanguíneo (J); êmbolo vascular (K) e invasão perineural (L) (hematoxilina e eosina, aumento original X400). 
Quadro 6: Resumo das informações clínicas e histopatológicas dos 35 casos de melanoma primário da mucosa oral

\begin{tabular}{|c|c|c|c|c|}
\hline & & \multirow[t]{2}{*}{ Variáveis } & \multicolumn{2}{|c|}{ valores } \\
\hline & & & (n) & $(n \%)$ \\
\hline & & $0-20$ & 1 & 2.85 \\
\hline & & $21-40$ & 2 & 5.71 \\
\hline & Idade & $41-60$ & 14 & 40 \\
\hline & (anos) & $61-80$ & 13 & 37.14 \\
\hline & & $>80$ & 5 & 14.28 \\
\hline \multirow{14}{*}{$\begin{array}{l}\text { Informações } \\
\text { clínicas }\end{array}$} & & Masculino & 18 & 51.43 \\
\hline & sexo & Feminino & 17 & 48.57 \\
\hline & & Caucasianos & 21 & 75 \\
\hline & Etnias & outros & 7 & 25 \\
\hline & & Palato/rebordo superior & 25 & 71.42 \\
\hline & & Trígono retromolara/soalho & 3 & 8.57 \\
\hline & & Mucosa labial & 3 & 8.57 \\
\hline & Localização & Mucosa jugal/ mucosa vestibular & 2 & 5,71 \\
\hline & & Língua & 1 & 2.86 \\
\hline & & Não informada & 1 & 2.86 \\
\hline & & 1 & 1 & 2.94 \\
\hline & & II & 5 & 14.71 \\
\hline & Nível & III & 28 & 82.35 \\
\hline & & Não informada & 1 & 2.94 \\
\hline \multirow{11}{*}{$\begin{array}{l}\text { Análise } \\
\text { histopatológica }\end{array}$} & Composição & Monomorfa & 18 & 51.42 \\
\hline & celular & polimorfa & 17 & 48.58 \\
\hline & & ausente & 1 & 2.86 \\
\hline & Melanına & presente & 34 & 97.14 \\
\hline & & ausente & 19 & 54.29 \\
\hline & Necrose & presente & 16 & 45.71 \\
\hline & & ausente & 13 & 37.14 \\
\hline & Invasao & Presente & 20 & 60.61 \\
\hline & vascular & Não informada & 2 & 2.24 \\
\hline & Invasão & Ausente & 26 & 74.29 \\
\hline & perineural & Presente & 9 & 25.71 \\
\hline
\end{tabular}


Quadro 7: Relação entre recorrências e parâmetros histológicos dos melanomas estudados

\begin{tabular}{|c|c|c|c|c|}
\hline \multicolumn{2}{|c|}{ Variáveis } & \multicolumn{2}{|c|}{ Recorrência } & \multirow[t]{2}{*}{ Valor $p$} \\
\hline & & Não (n\%) & $\operatorname{Sim}(n \%)$ & \\
\hline \multirow{3}{*}{ Nível } & I & $1(33.33 \%)$ & 0 & 0.142 \\
\hline & ॥ & 0 & $2(10 \%)$ & \\
\hline & III & $2(66.67 \%)$ & $18(90 \%)$ & \\
\hline \multirow[t]{2}{*}{ Tipo celular } & Monomorfo & $2(66.67 \%)$ & $8(38.1 \%)$ & 0.550 \\
\hline & polimorfo & $1(33.33 \%)$ & $13(61.9 \%)$ & \\
\hline \multirow[t]{2}{*}{ Melanina } & Ausente & $1(33.33 \%)$ & $1(4.76 \%)$ & 0.239 \\
\hline & Presente & $2(66.67 \%)$ & $20(95.24 \%)$ & \\
\hline \multirow[t]{2}{*}{ Necrose } & Ausente & $3(100 \%)$ & $10(50 \%)$ & 0.229 \\
\hline & Presente & 0 & $10(50 \%)$ & \\
\hline \multirow[t]{2}{*}{ Invasão vascular } & Ausente & $1(33.33 \%)$ & $4(20 \%)$ & 0.539 \\
\hline & Presente & $2(66.67 \%)$ & $16(80 \%)$ & \\
\hline \multirow[t]{2}{*}{ Invasão perineural } & Ausente & $2(66.67 \%)$ & $19(95 \%)$ & 0.249 \\
\hline & presente & $1(33.33 \%)$ & $1(5 \%)$ & \\
\hline
\end{tabular}


Gráfico 1: Distribuição do melanoma primário da mucosa oral segundo o gênero (homens (51.43\%) e (48.57\%) mulheres)

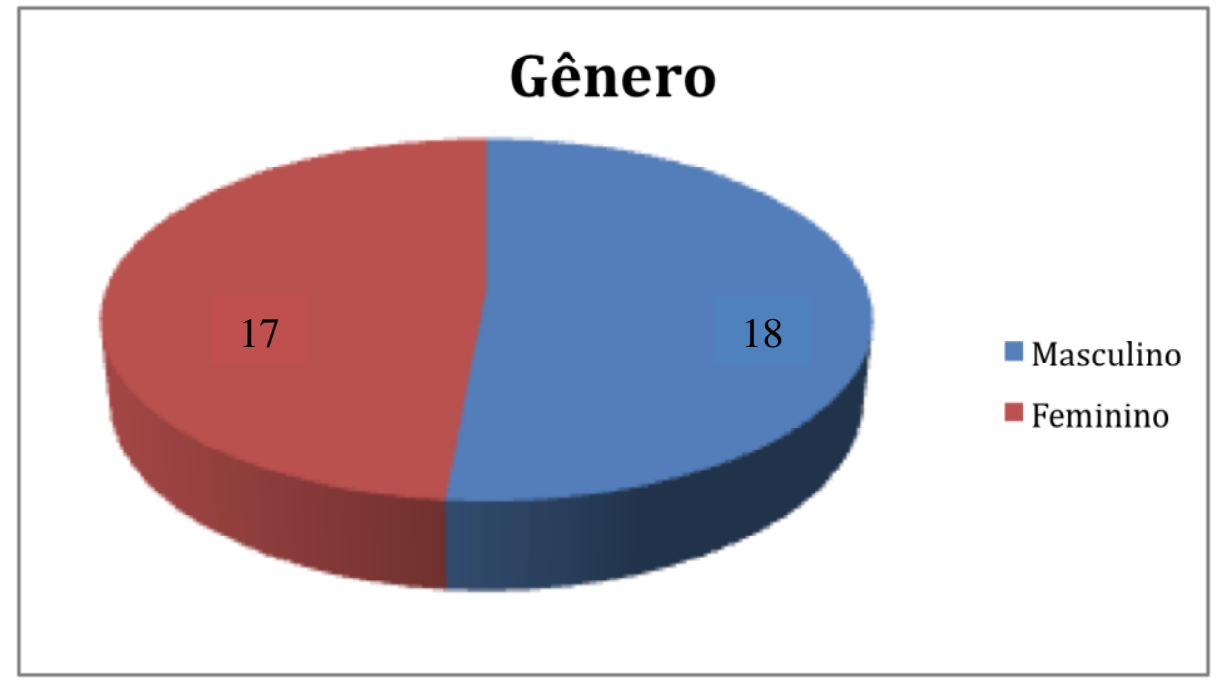

Gráfico 2: Distribuição do melanoma primário da mucosa oral por raça (brancos: $75 \%$ e não-brancos 25\%)

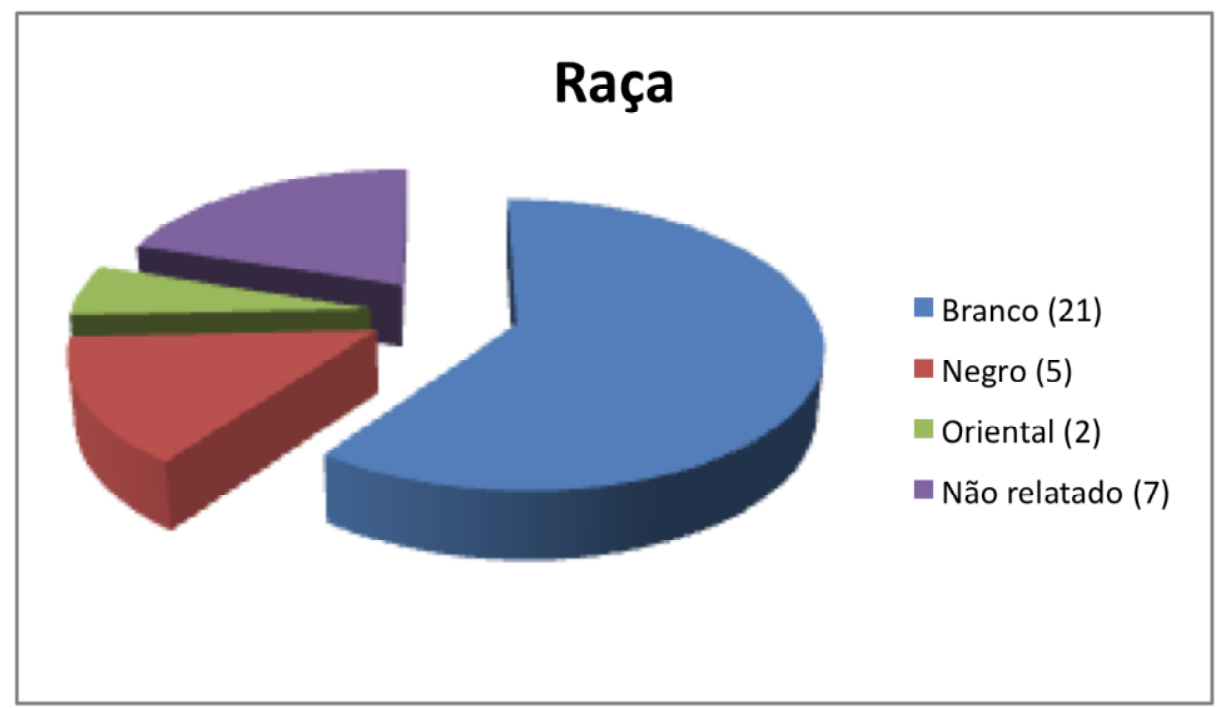


Gráfico 3: Localização das lesões de melanoma primário da mucosa oral

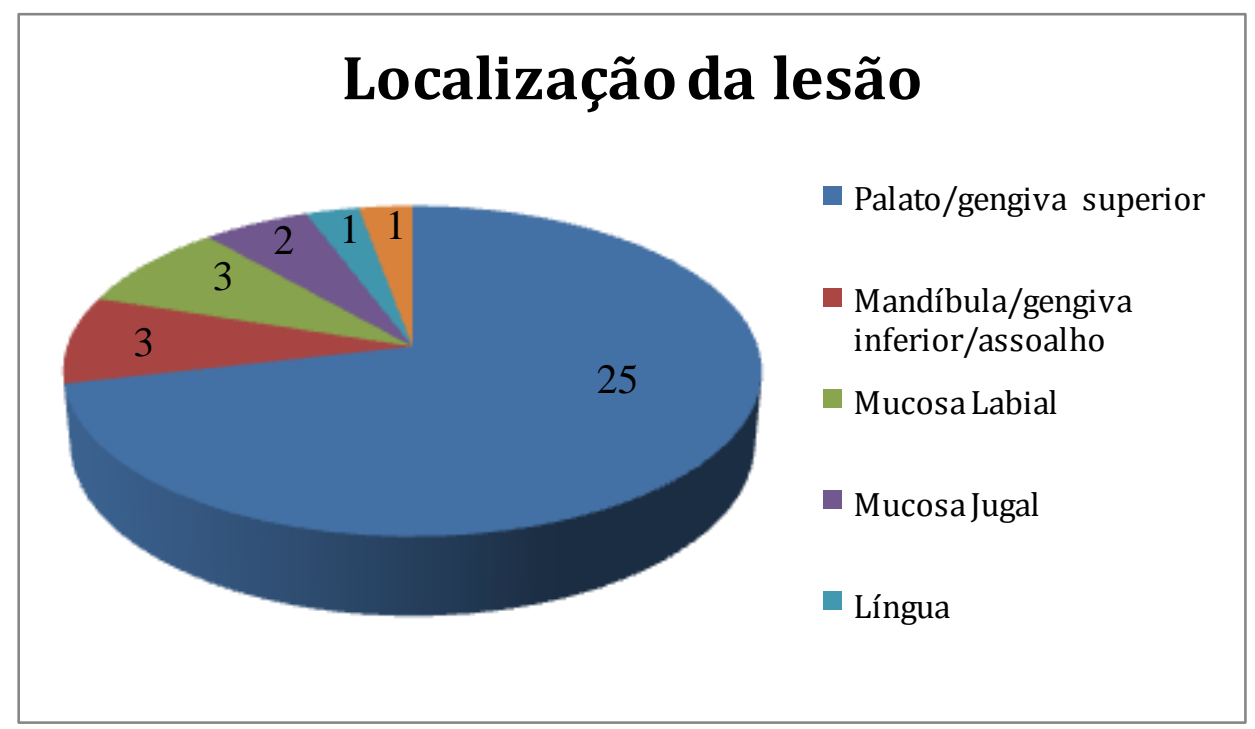

Gráfico 4: Análise do nível histológico dos melanomas primários da mucosa oral

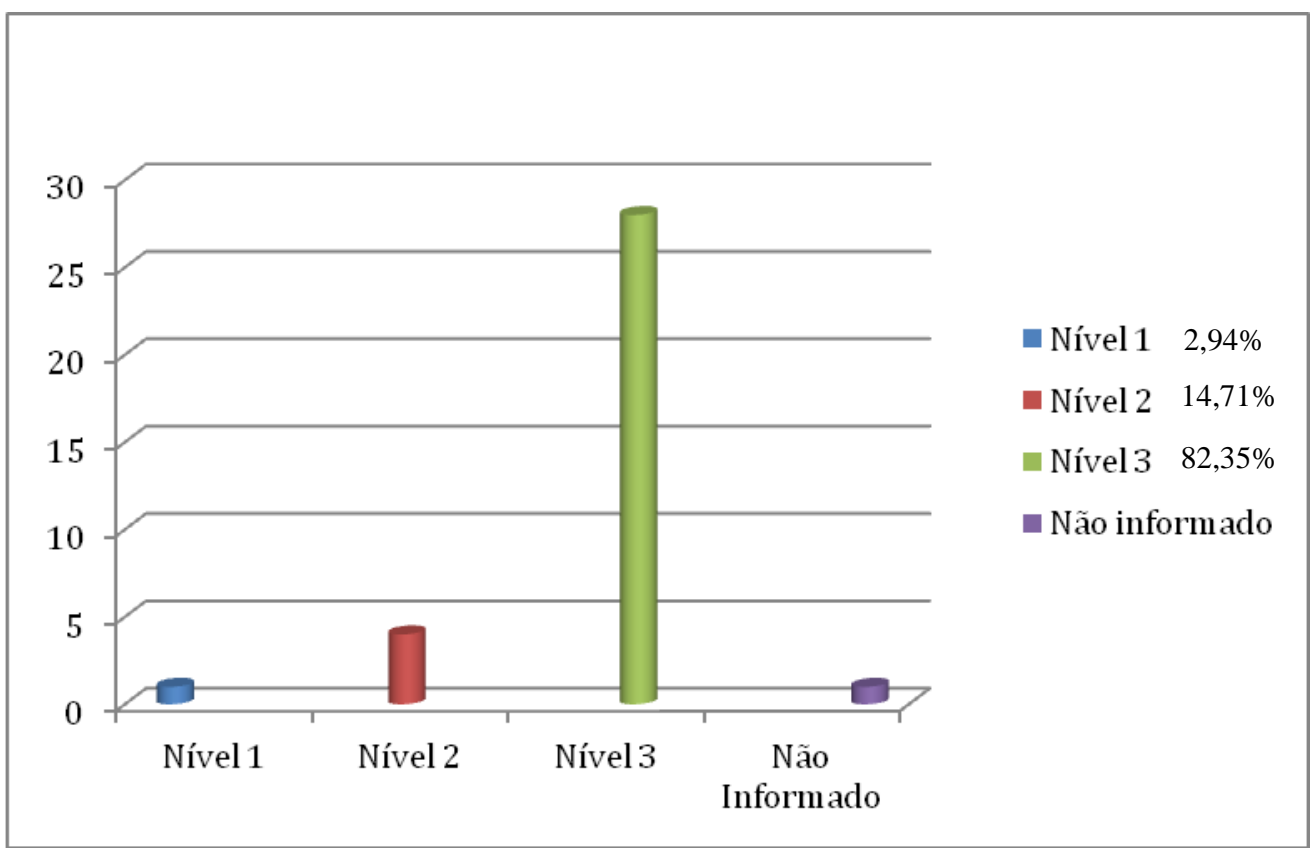




\subsection{RESULTADOS DA ANÁLISE IMUNOISTOQUÍMICA DOS TMAs DE MELANOMAS} PRIMÁRIOS DA MUCOSA ORAL

A análise semi-quantitativa da expressão proteica dos componentes da via MAPK estudada foi realizada por dois pesquisadores, e os resultados foram correlacionados com os aspectos clínico-histopatológico dos casos selecionados através do teste exato de Fisher (vide Quadro 8).

A expressão das proteínas da cascata MAPK foi alterada na maioria dos casos. RAS foi positivo para $28,57 \%$ (marcação em membrana e citoplasma) nos casos estudados; BRAF e ERK2 foram superexpressos na maioria dos casos $(82,85 \%$ (marcação citoplasmática) e 74,28\% (padrão citoplasmática e nuclear quando presente), respectivamente); MEK2 apresentou positividade em 51,43\% (padrão citoplasmático) dos casos, enquanto ERK1 apresentaram uma expressão diminuída em $80 \%$ dos casos (predominantemente padrão citoplasmático e nuclear quando presente). Expressão do MEK1 não foi detectada em nenhum caso. (Figura 4)

Sendo assim, a menor expressão das proteínas RAS e ERK1 e a positividade para BRAF e ERK2 foram correlacionados com alto grau histológico, invasão vascular e metástase a distância. Adicionalmente a expressão de MEK2 foi estatisticamente significante ao correlacionar com a invasão vascular $(p=0,043)$. 
Figura 4: Aspectos imunoistoquímicos da expressão das proteínas componentes da via da MAPK nos melanomas primários da mucosa oral

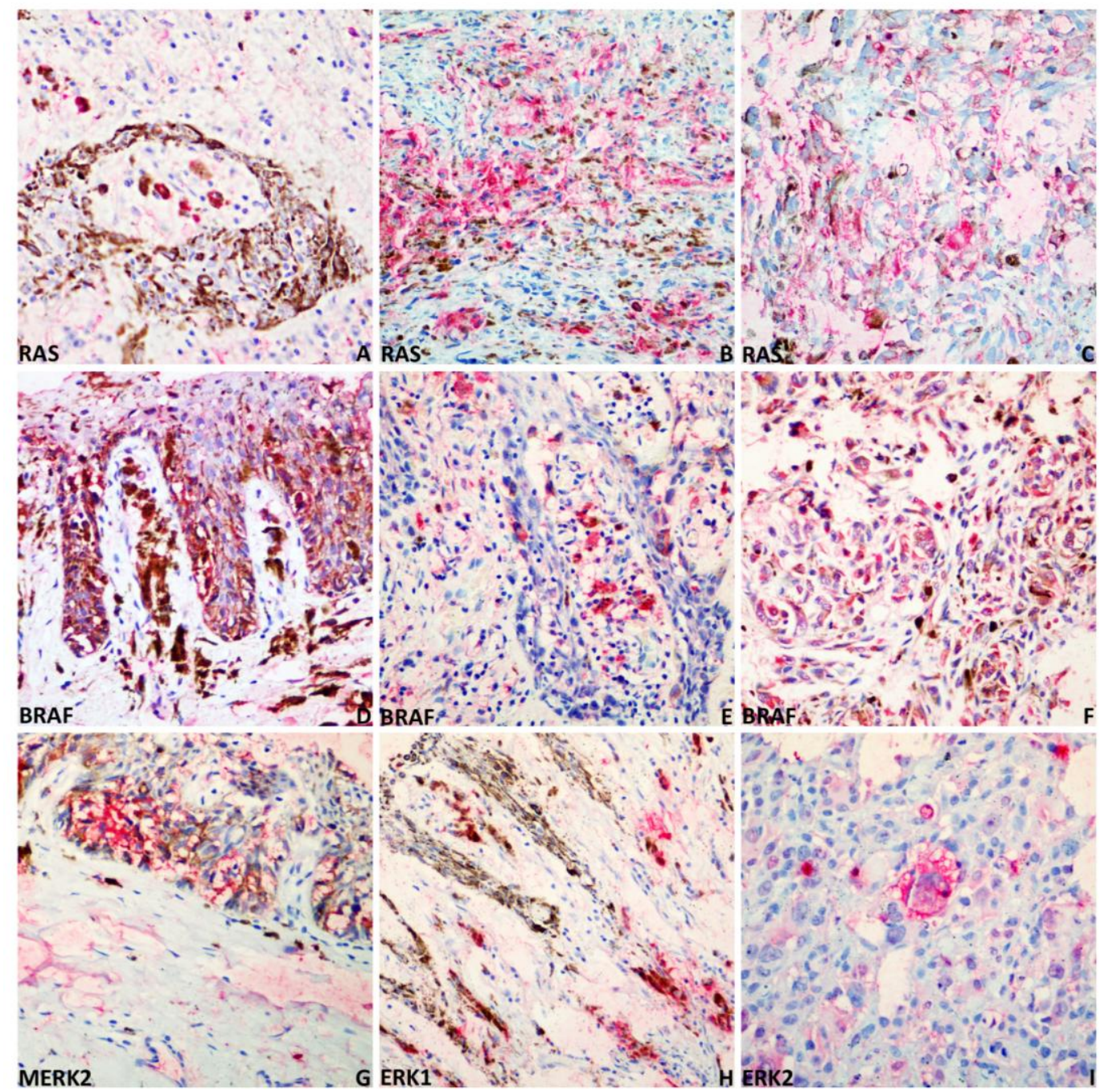

FIGURA 4 


\section{LEGENDA DA FIGURA 4: ASPECTOS IMUNOISTOQUIMICOS DA EXPRESSÃO DAS PROTEÍNAS COMPONENTES DA VIA DA MAPK NOS MELANOMAS PRIMÁRIOS DA MUCOSA ORAL}

A, B e C: Expressão imunoistoquímica da proteína RAS nos melanomas primários da mucosa oral: presença de células isoladas positivas para RAS entre área pigmentada do tumor (A); em B e C positividade difusa da proteína. A marcação foi localizada na membrana celular e no citoplasma. Aumento original X 400).

D, E, e F: Expressão imunoistoquímica da proteína BRAF nos melanomas primários da mucosa oral: melanócitos neoplásicos positivos no melanoma in situ (D) e em melanomas francamente invasivos (E e F). A marcação foi localizada no citoplasma. Aumento original $\times 400$.

G: Expressão da proteína MEK2 no componente in situ do melanoma primário da mucosa oral. A marcação foi localizada no citoplasma. Aumento original X400.

H: Imunoexpressão da proteína ERK1 em áreas focais de melanoma primário da mucosa oral nível II. A marcação foi localizada no citoplasma e no núcleo quando presente. Aumento original X400.

I: Imunoexpressão da proteína ERK2 em células isoladas do melanoma primário da mucosa oral. A marcação foi localizada no citoplasma e no núcleo quando presente. Aumento original $\times 400$. 
Quadro 8: Associação entre expressão das proteína da via MAPK e os parâmetros clínico-patológicos dos melanomas primários da mucosa oral

\begin{tabular}{|c|c|c|c|c|c|c|c|c|c|c|c|c|c|c|c|c|}
\hline & Casos & & Ras & & & BRAF & & & MEK2 & & & ERK1 & & & ERk2 & \\
\hline & & $\mathrm{Neg}(\%)$ & Pos (\%) & $P$ value & $\mathrm{Neg}(\%)$ & Pos (\%) & $P$ value & $\mathrm{Neg}(\%)$ & Pos (\%) & $P$ value & $\mathrm{Neg}(\%)$ & Pos $(\%)$ & $P$ value & $\mathrm{Neg}(\%)$ & Pos(\%) & $P$ value \\
\hline $\begin{array}{l}\text { Gênero } \\
\text { Feminino } \\
\text { Masculino }\end{array}$ & $\begin{array}{l}17 \\
18\end{array}$ & $\begin{array}{l}11(69) \\
12(71)\end{array}$ & $\begin{array}{l}05(82) \\
05(29)\end{array}$ & 0.909 & $\begin{array}{l}03(18) \\
04(22)\end{array}$ & $\begin{array}{l}14(82) \\
14(78)\end{array}$ & 1.000 & $\begin{array}{l}10(59) \\
06(35)\end{array}$ & $\begin{array}{l}07(41) \\
11(65)\end{array}$ & 0.1609 & $\begin{array}{l}12(75) \\
14(82)\end{array}$ & $\begin{array}{l}04(25) \\
03(18)\end{array}$ & 0.688 & $\begin{array}{l}04(27) \\
02(12)\end{array}$ & $\begin{array}{l}11(73) \\
15(88)\end{array}$ & 0,383 \\
\hline $\begin{array}{l}\text { Recorrência } \\
\text { Não } \\
\text { Sim }\end{array}$ & $\begin{array}{l}14 \\
11\end{array}$ & $\begin{array}{l}10(71) \\
06(55)\end{array}$ & $\begin{array}{l}04(29) \\
05(45)\end{array}$ & 0.734 & $\begin{array}{l}03(22) \\
01(09)\end{array}$ & $\begin{array}{l}11(78) \\
10(91)\end{array}$ & 0.626 & $\begin{array}{l}06(43) \\
04(36)\end{array}$ & $\begin{array}{l}08(57) \\
07(74)\end{array}$ & 0.405 & $\begin{array}{l}13(93) \\
06(66)\end{array}$ & $\begin{array}{l}01(07) \\
03(24)\end{array}$ & 1.000 & $\begin{array}{l}01(7) \\
02(20)\end{array}$ & $\begin{array}{l}13(93) \\
08(80)\end{array}$ & 0.543 \\
\hline $\begin{array}{l}\text { Metástase } \\
\text { Sem } \\
\text { Com }\end{array}$ & $\begin{array}{l}04 \\
21\end{array}$ & $\begin{array}{l}01(25) \\
16(76)\end{array}$ & $\begin{array}{l}03(75) \\
05(24)\end{array}$ & 0.194 & $\begin{array}{l}00 \\
04(19)\end{array}$ & $\begin{array}{l}04(100) \\
17(81)\end{array}$ & 1.000 & $\begin{array}{l}01(25) \\
9(43)\end{array}$ & $\begin{array}{l}03(75) \\
12(57)\end{array}$ & 0.266 & $\begin{array}{l}03(75) \\
18(86)\end{array}$ & $\begin{array}{l}01 \\
03(14)\end{array}$ & 1.000 & $\begin{array}{l}00 \\
03(14)\end{array}$ & $\begin{array}{c}04(100) \\
18(86)\end{array}$ & 1.000 \\
\hline $\begin{array}{l}\text { Grau histológico } \\
\text { II } \\
\text { III }\end{array}$ & $\begin{array}{c}6 \\
29\end{array}$ & $\begin{array}{l}03(60) \\
20(71)\end{array}$ & $\begin{array}{l}02(40) \\
08(29)\end{array}$ & 1.000 & $\begin{array}{l}00 \\
07(24)\end{array}$ & $\begin{array}{l}06(100) \\
22(76)\end{array}$ & 0.562 & $\begin{array}{l}03(50) \\
11(41)\end{array}$ & $\begin{array}{l}03(50) \\
08(59)\end{array}$ & 0.375 & $\begin{array}{l}03(60) \\
23(82)\end{array}$ & $\begin{array}{l}02(40) \\
05(18)\end{array}$ & 1.000 & $\begin{array}{l}00 \\
05(18.5)\end{array}$ & $\begin{array}{r}04(100) \\
\text { 5) } 22(81.5)\end{array}$ & 1.000 \\
\hline $\begin{array}{l}\text { Tipo celular } \\
\text { Monomorfico } \\
\text { Polimorfico }\end{array}$ & $\begin{array}{l}15 \\
16\end{array}$ & $\begin{array}{l}08(53) \\
13(81)\end{array}$ & $\begin{array}{l}07(47) \\
03(19)\end{array}$ & 0.097 & $\begin{array}{l}04(25) \\
02(12)\end{array}$ & $\begin{array}{l}12(75) \\
15(88)\end{array}$ & 0.398 & $\begin{array}{l}10(62.5) \\
14(87.5)\end{array}$ & $\begin{array}{l}06(37.5) \\
02(12,5)\end{array}$ & 0.220 & $\begin{array}{l}10(67) \\
14(87.5)\end{array}$ & $\begin{array}{l}05(33) \\
02(12.5)\end{array}$ & 0.220 & $\begin{array}{l}03(21) \\
03(19)\end{array}$ & $\begin{array}{l}11(79) \\
13(81)\end{array}$ & 1.000 \\
\hline $\begin{array}{l}\text { Necrose } \\
\text { Ausente } \\
\text { Presente }\end{array}$ & $\begin{array}{l}20 \\
15\end{array}$ & $\begin{array}{l}11(58) \\
11(84)\end{array}$ & $\begin{array}{l}08(42) \\
02(16)\end{array}$ & 0.099 & $\begin{array}{l}03(15) \\
04(26)\end{array}$ & $\begin{array}{l}17(80) \\
11(74)\end{array}$ & 1.000 & $\begin{array}{l}10(50) \\
06(55)\end{array}$ & $\begin{array}{l}10(50) \\
05(45)\end{array}$ & 1.000 & $\begin{array}{l}13(68) \\
13(93)\end{array}$ & $\begin{array}{l}06(32) \\
01(07)\end{array}$ & 0.066 & $\begin{array}{l}03(16) \\
05(36)\end{array}$ & $\begin{array}{c}15(88) \\
09(64)\end{array}$ & 0.622 \\
\hline $\begin{array}{l}\text { Invasão vascular } \\
\text { Ausente } \\
\text { Presente }\end{array}$ & $\begin{array}{l}13 \\
20\end{array}$ & $\begin{array}{l}08(61) \\
13(68)\end{array}$ & $\begin{array}{l}04(39) \\
06(32)\end{array}$ & 0.716 & $\begin{array}{l}02(15) \\
03(16)\end{array}$ & $\begin{array}{l}11(85) \\
16(84)\end{array}$ & 0.643 & $\begin{array}{l}08(62) \\
05(30)\end{array}$ & $\begin{array}{l}05(38) \\
12(70)\end{array}$ & 0.043 & $\begin{array}{l}08(66) \\
16(89)\end{array}$ & $\begin{array}{l}04(36) \\
02(11)\end{array}$ & 0.151 & $\begin{array}{l}03(27) \\
03(16)\end{array}$ & $\begin{array}{l}08(73) \\
15(84)\end{array}$ & 1.000 \\
\hline $\begin{array}{l}\text { Invasão } \\
\text { perineural } \\
\text { Ausente } \\
\text { Presente } \\
\end{array}$ & $\begin{array}{l}25 \\
08\end{array}$ & $\begin{array}{l}16(70) \\
05(62)\end{array}$ & $\begin{array}{l}07(30) \\
03(38)\end{array}$ & 0,353 & $\begin{array}{l}05(22) \\
00\end{array}$ & $\begin{array}{c}18(78) \\
08(100)\end{array}$ & 0.156 & $\begin{array}{l}10(45) \\
02(40)\end{array}$ & $\begin{array}{l}12(55) \\
06(60)\end{array}$ & 0.235 & $\begin{array}{l}17(74) \\
08(100)\end{array}$ & $\begin{array}{l}06(26) \\
00\end{array}$ & 0.145 & $\begin{array}{l}04(18) \\
02(25)\end{array}$ & $\begin{array}{c}18(82) \\
06(75)\end{array}$ & 0.622 \\
\hline $\begin{array}{l}\text { Melanina } \\
\text { Ausente } \\
\text { Presente }\end{array}$ & $\begin{array}{l}10 \\
12\end{array}$ & $\begin{array}{l}10(100) \\
12(54.5)\end{array}$ & $\begin{array}{l}0 \\
10(45.5)\end{array}$ & 0.010 & $\begin{array}{l}04(40) \\
03(12.5)\end{array}$ & $\begin{array}{l}06(60) \\
21(87.5)\end{array}$ & 0.157 & $\begin{array}{l}05(50) \\
10(43.5)\end{array}$ & $\begin{array}{l}05(50) \\
13(56.5)\end{array}$ & 0.730 & $\begin{array}{l}09(90) \\
17(77)\end{array}$ & $\begin{array}{l}01(10) \\
05(23)\end{array}$ & 0.393 & $\begin{array}{l}03(30) \\
02(9.5)\end{array}$ & $\begin{array}{l}07(70) \\
19(90.5)\end{array}$ & 0.296 \\
\hline
\end{tabular}


5.3 RESUlTAdOS DA ANÁLISE MOLECULAR DE MELANOMAS PRIMÁRIOS DA MUCOSA ORAL

Devido à raridade e escassez do material e a dificuldade da técnica de extrair DNA íntegro de tecidos conservados em parafina, foi possível realizar o estudo da mutação pontual dos genes BRAF, NRAS e KRAS apenas em 14 casos de melanomas orais, através da técnica de pirosequenciamento. A análise dos dados obtidos foi realizada por dois pesquisadores :

5.3.1 Análise da mutação do gene BRAF, códon 600 foi realizada por meio de métodos de bioinformática através do programa PSQ 96MA SNP/Pyromark ID. O tipo selvagem apresenta nesta região nucleotídeos $T / T$, porém observamos a incorporação de A no lugar de T (T>A) em 9 casos (Quadro 9 e Figuras 5 a 19).

5.3.2 Análise da mutação do gene NRAS, códons 12 e 13 será realizada por meio de métodos de bioinformática através do programa Pyromark ${ }^{\mathrm{TM}}$ Software. $\mathrm{O}$ tipo selvagem apresenta nesta região nucleotídeos $G / G$ nas posição 1 e G/G na posição 2. Porém foram observados incorporação de $T$ no lugar de $G(G>T)$ na posição 1 do códon 12 do gene NRAS em 2 casos (Quadro 9 e Figuras 5 a 19).

5.3.3 Análise de mutação do gene KRAS, códons 12 e 13, posição 2 foi realizada por meio de métodos de bioinformática com utilização do programa Pyromark $^{\mathrm{TM}}$ 
Software. Não foi observada nenhuma mutação neste gene em todos os casos analisados, todos foram considerados selvagens (Quadro 9 e Figuras 5 a 19). 
Quadro 9 : Resultados do pirosequenciamento de BRAF; NRAS e KRAS nos 14 casos analisados

\begin{tabular}{|c|c|c|c|c|c|c|c|c|c|c|c|}
\hline Caso & Sexo & Localização da lesão & $\begin{array}{c}\text { Nível } \\
\text { histológico }\end{array}$ & Necrose & $\begin{array}{l}\text { Invasão } \\
\text { vascular }\end{array}$ & $\begin{array}{l}\text { Invasão } \\
\text { perineural }\end{array}$ & $\begin{array}{l}\text { Recorrência } \\
\text { local }\end{array}$ & Metástase & $\begin{array}{l}\text { BRAF } \\
\text { Códon } 600\end{array}$ & $\begin{array}{c}\text { NRAS } \\
\text { Códons } 12 \text { e } 13\end{array}$ & $\begin{array}{c}\text { KRAS } \\
\text { Códons } 12 \text { e } 13\end{array}$ \\
\hline 6 & $\mathbf{F}$ & Palato duro & III & presente & ausente & ausente & Não & Sim & Mutado & Selvagem & Selvagem \\
\hline 7 & $\mathbf{F}$ & $\begin{array}{c}\text { Palato duro e rebordo } \\
\text { alveolar }\end{array}$ & III & presente & presente & presente & Sim & Sim & Mutado & Selvagem & Selvagem \\
\hline 9 & $\mathbf{F}$ & $\begin{array}{l}\text { Palato duro e rebordo } \\
\text { alveolar }\end{array}$ & III & ausente & presente & presente & Sim & Sim & Mutado & Selvagem & Selvagem \\
\hline 12 & $\mathbf{F}$ & $\begin{array}{c}\text { Lábio superior e sulco } \\
\text { vestibular }\end{array}$ & III & presente & ausente & ausente & Sim & $\begin{array}{c}\text { Não } \\
\text { informado }\end{array}$ & Mutado & Selvagem & Selvagem \\
\hline 13 & M & $\begin{array}{l}\text { Palato duro e rebordo } \\
\text { alveolar }\end{array}$ & III & presente & presente & ausente & Não & Sim & Mutado & Selvagem & Selvagem \\
\hline 14 & $\mathbf{F}$ & $\begin{array}{c}\text { Palato duro e rebordo } \\
\text { alveolar }\end{array}$ & II & presente & presente & presente & Não & Sim & Selvagem & Mutado & Selvagem \\
\hline 17 & M & Palato duro & III & presente & presente & presente & Não & Sim & Selvagem & Mutado & Selvagem \\
\hline 18 & M & $\begin{array}{l}\text { Soalho, mucosa jugal, } \\
\text { borda lateral da lingua } \\
\text { e palato mole }\end{array}$ & III & presente & presente & ausente & Não & Sim & Selvagem & Selvagem & Selvagem \\
\hline 19 & M & $\begin{array}{c}\text { Palato duro e rebordo } \\
\text { alveolar }\end{array}$ & III & ausente & presente & presente & Não & Não & Mutado & Selvagem & Selvagem \\
\hline 23 & $\mathbf{F}$ & $\begin{array}{c}\text { Palato duro e mucosa } \\
\text { vestibular }\end{array}$ & III & presente & presente & presente & Sim & Sim & Mutado & Selvagem & Selvagem \\
\hline 25 & M & Palato duro & III & ausente & presente & ausente & Sim & Sim & Mutado & Selvagem & Selvagem \\
\hline 26 & M & $\begin{array}{l}\text { Trígono retormolar e } \\
\text { palato mole }\end{array}$ & III & ausente & ausente & ausente & $\begin{array}{c}\text { Não } \\
\text { informado }\end{array}$ & Sim & Selvagem & Selvagem & Selvagem \\
\hline 31 & M & Mucosa labial & III & presente & presente & ausente & $\begin{array}{c}\text { Não } \\
\text { informado }\end{array}$ & $\begin{array}{c}\text { Não } \\
\text { informado }\end{array}$ & Selvagem & Selvagem & Selvagem \\
\hline 35 & M & Palato duro & II & ausente & ausente & ausente & Não & Não & Mutado & Selvagem & Selvagem \\
\hline
\end{tabular}


Figura 5: Pirogramas de BRAF, KRAS e NRAS do Caso 6

\begin{tabular}{|c|c|c|c|}
\hline Pirosequenciamento & BRAF & NRAS & KRAS \\
& Códon 600 & Códon 12 e 13 & Códon 12 e 13 \\
\hline Caso 6 & Mutado & Selvagem & Selvagem \\
\hline
\end{tabular}

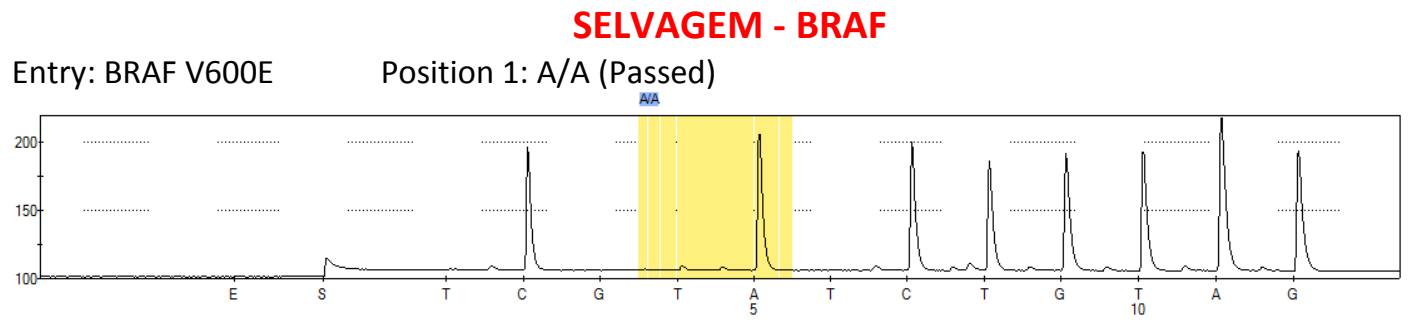

SELVAGEM - NRAS

Entry: NRAS 12-13 Position 1: G/G (Passed), Position 2: G/G (Passed)

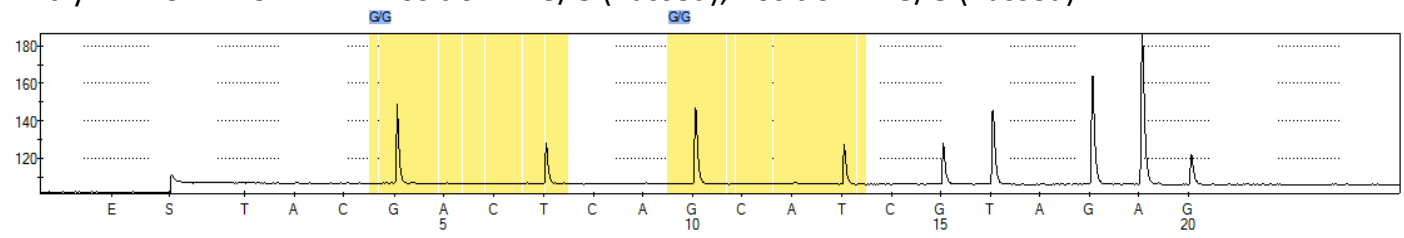

SELVAGEM - KRAS

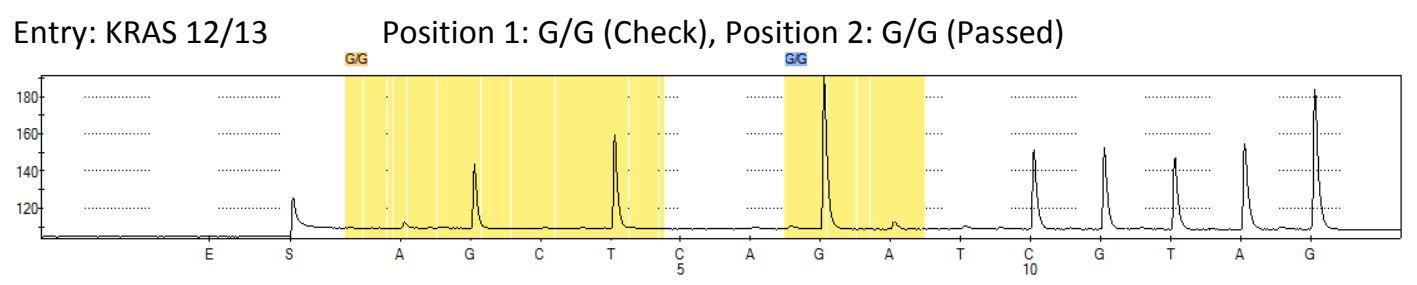


Figura 6: Pirogramas de BRAF, NRAS e KRAS do Caso 7

\begin{tabular}{|c|c|c|c|}
\hline Pirosequenciamento & BRAF & NRAS & KRAS \\
\hline Caso 7 & Códon 600 & Códon 12 e 13 & Códon 12 e 13 \\
\hline
\end{tabular}

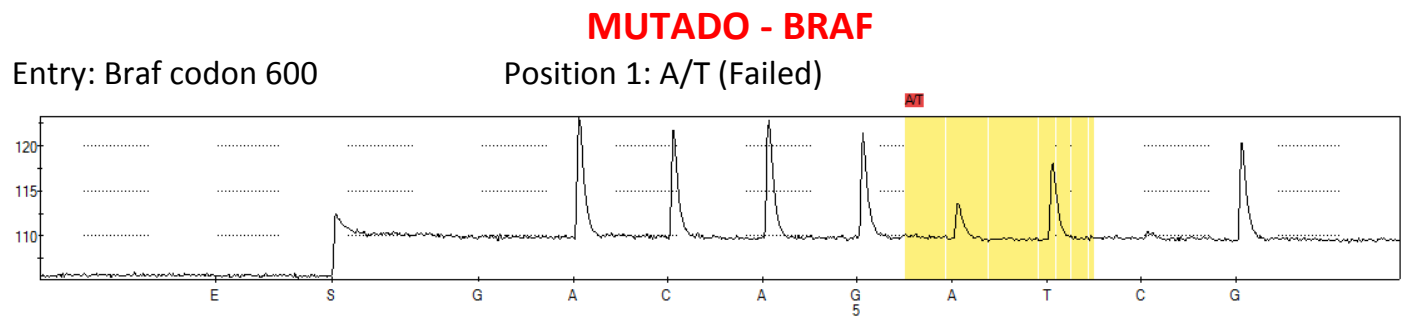

\section{SELVAGEM - NRAS}

Entry: NRAS 12-13 Position 1: G/G (Passed), Position 2: G/G (Passed)

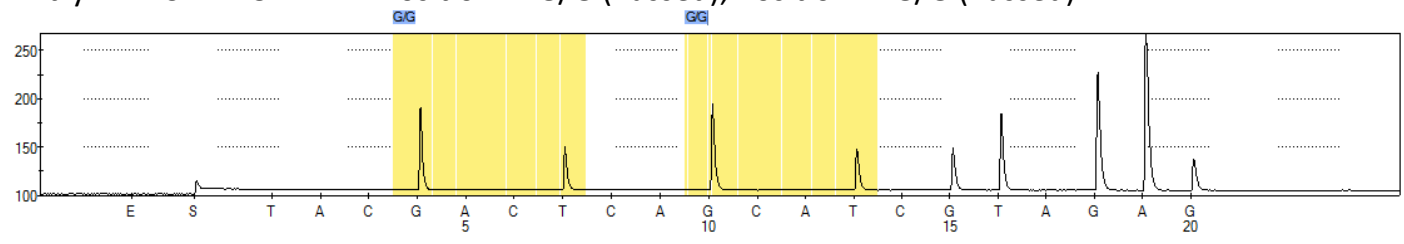

SELVAGEM - KRAS

Entry: KRAS codons 12 e 13 V2.0 Position 1: G/G (Passed), Position 2: G/G (Passed)

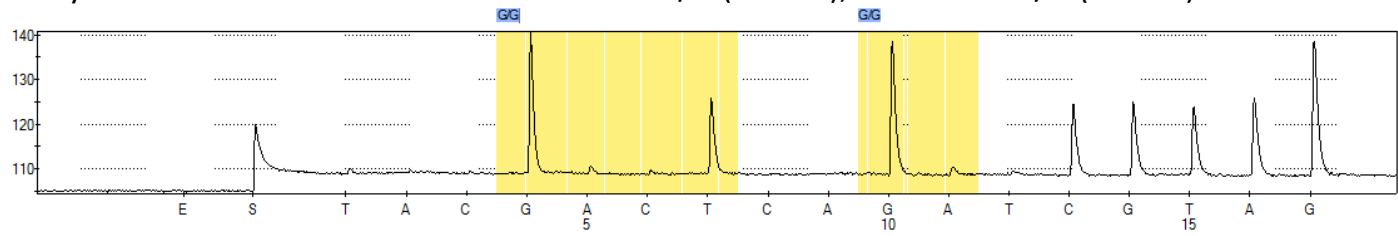


Figura 7: Pirogramas de BRAF, NRAS e KRAS do Caso 9

\begin{tabular}{|c|c|c|c|}
\hline Pirosequenciamento & $\begin{array}{c}\text { BRAF } \\
\text { Códon } 600\end{array}$ & $\begin{array}{c}\text { NRAS } \\
\text { Códon } 12 \text { e } 13\end{array}$ & $\begin{array}{c}\text { KRAS } \\
\text { Códon } 12 \text { e 13 }\end{array}$ \\
\hline Caso 9 & Mutado & Selvagem & Selvagem \\
\hline
\end{tabular}

MUTADO - BRAF

Entry: Braf codon 600 Position 1: T/T (Check)

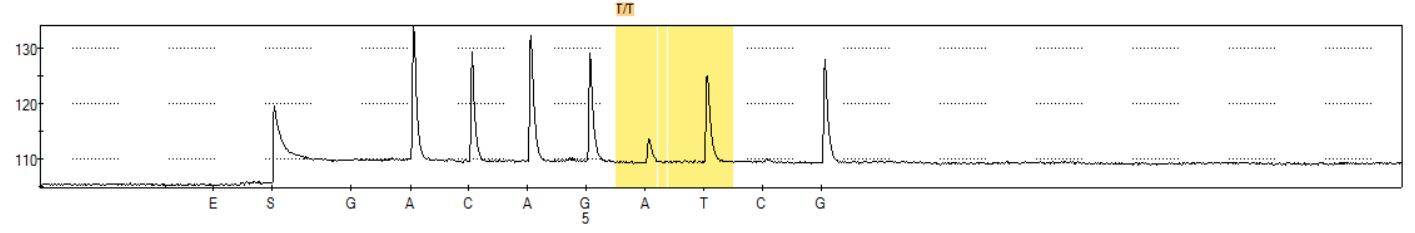

\section{SELVAGEM -NRAS}

Entry: NRAS 12-13 Position 1: G/G (Passed), Position 2: G/G (Passed)

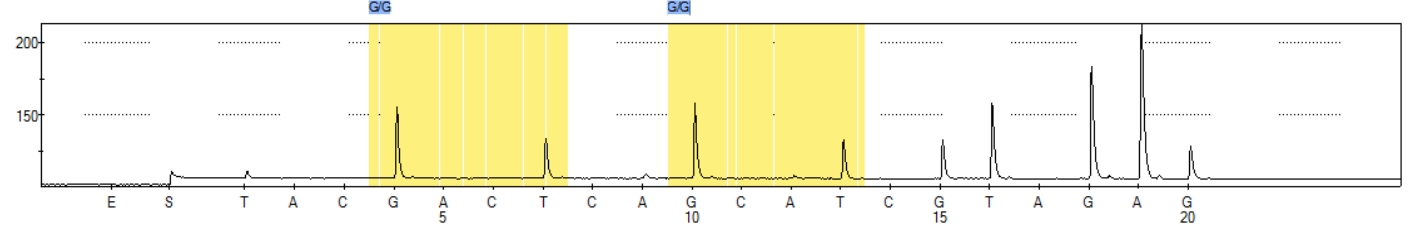

SELVAGEM - KRAS

Entry: KRAS codons 12 e 13 V2.0 Position 1: G/G (Passed), Position 2: G/G (Passed)

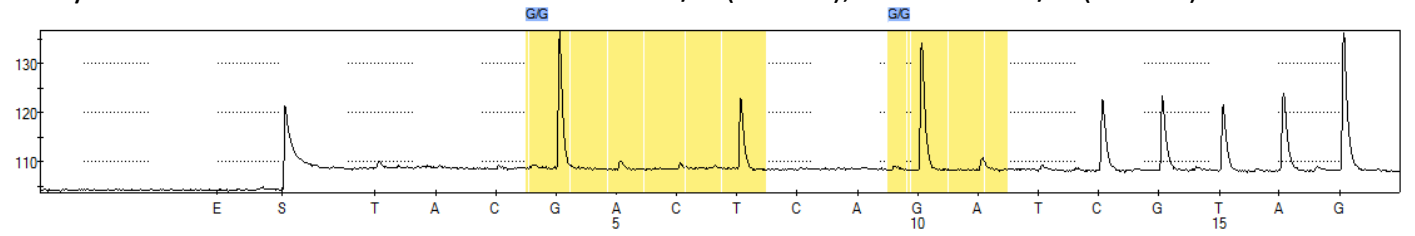


Figura 8: Pirogramas de BRAF, NRAS e KRAS do Caso 12

\begin{tabular}{|c|c|c|c|}
\hline Pirosequenciamento & BRAF & NRAS & KRAS \\
& Códon 600 & Códon 12 e 13 & Códon 12 e 13 \\
\hline Caso 12 & Mutado & Selvagem & Selvagem \\
\hline
\end{tabular}

MUTADO - BRAF

Entry: Braf codon $600 \quad$ Position 1: T/T (Check)

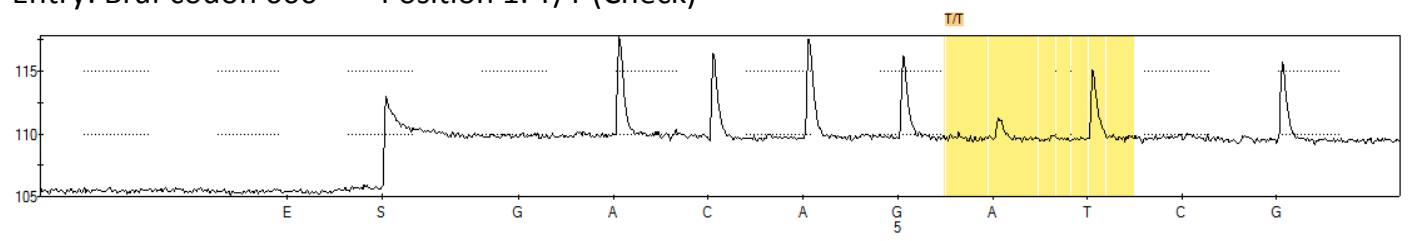

SELVAGEM - NRAS

Entry: NRAS 12-13 Position 1: G/G (Passed), Position 2: G/G (Passed) )

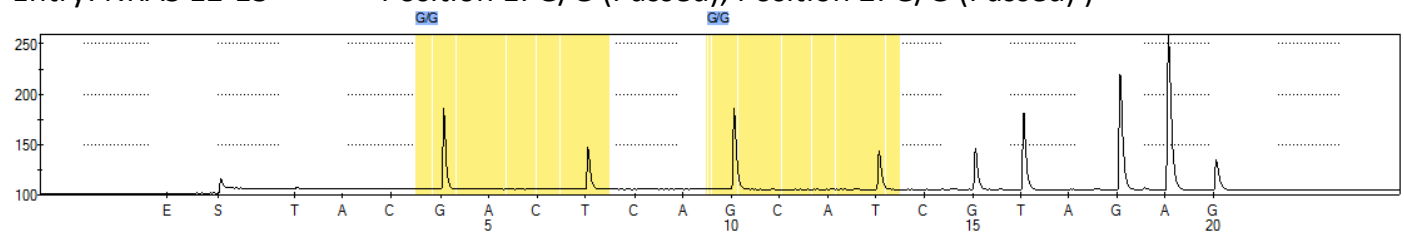

SELVAGEM - KRAS

Entry: KRAS codons 12 e 13 V2.0 Position 1: G/G (Passed), Position 2: G/G (Passed)

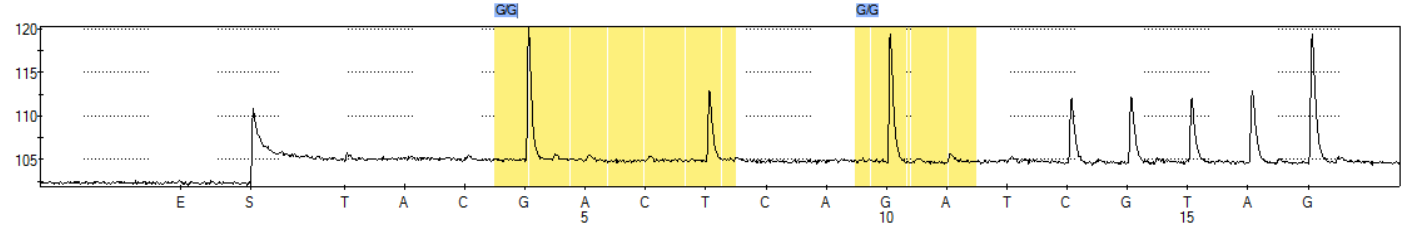


Figura 9: Pirogramas de BRAF, NRAS e KRAS do Caso 13

\begin{tabular}{|c|c|c|c|}
\hline Pirosequenciamento & $\begin{array}{c}\text { BRAF } \\
\text { Códon } 600\end{array}$ & $\begin{array}{c}\text { NRAS } \\
\text { Códon } 12 \text { e } 13\end{array}$ & $\begin{array}{c}\text { KRAS } \\
\text { Códon } 12 \text { e } 13\end{array}$ \\
\hline Caso 13 & Mutado & Selvagem & Selvagem \\
\hline
\end{tabular}
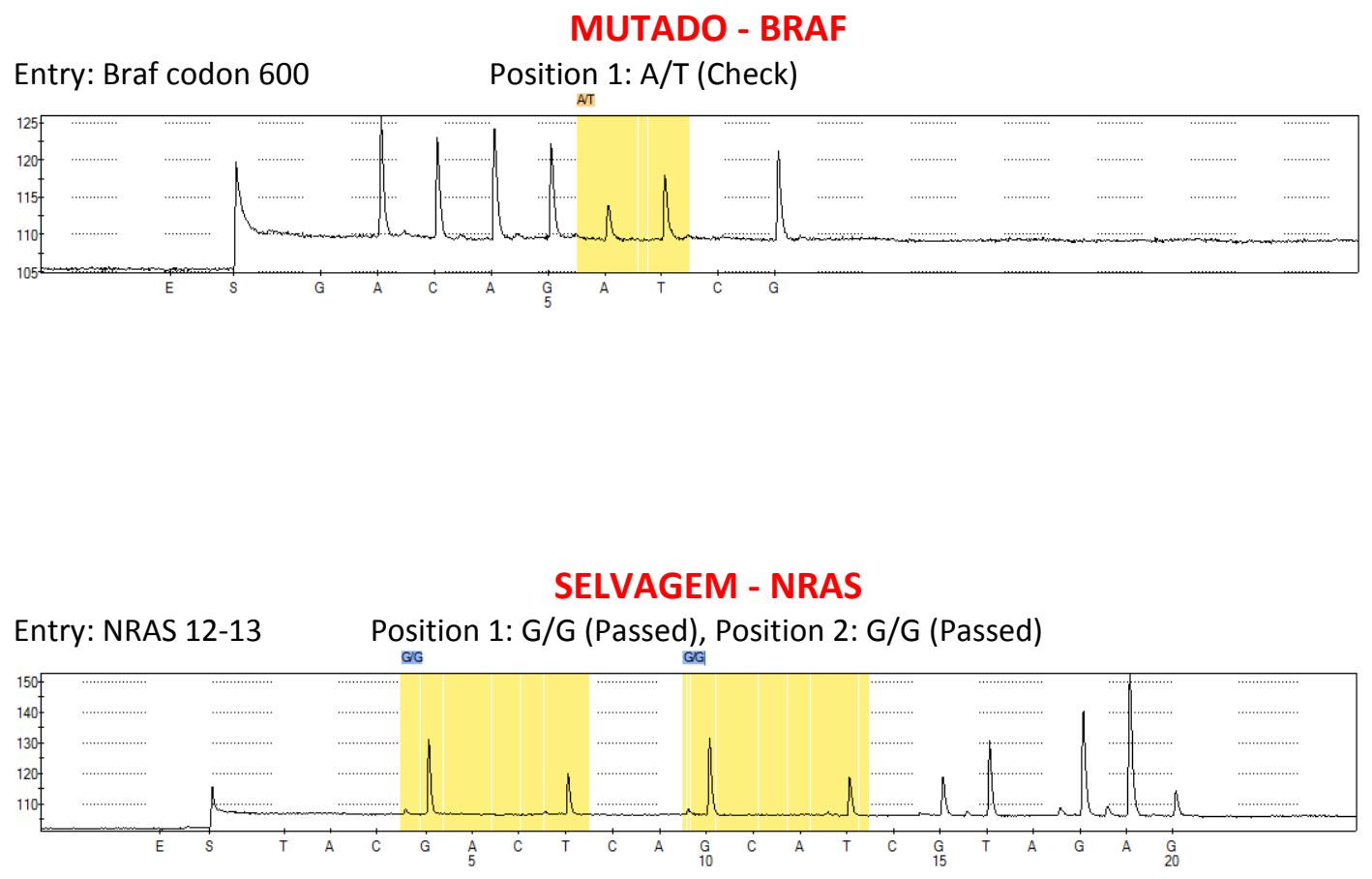

SELVAGEM - KRAS

Entry: KRAS codons 12 e 13 V2.0 Position 1: G/G (Passed), Position 2: G/G (Passed)

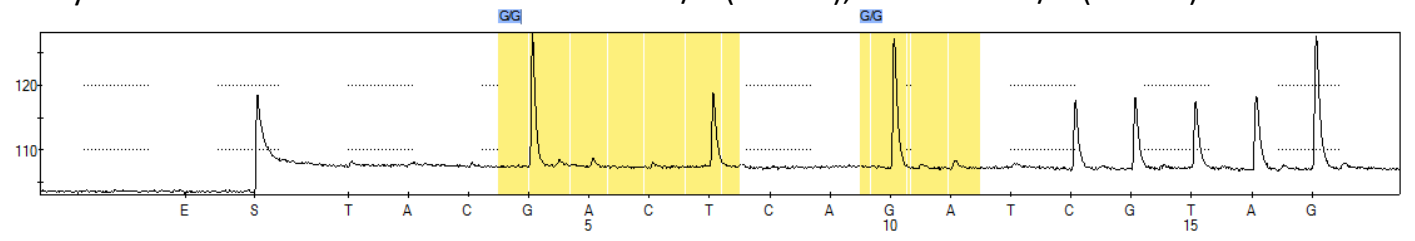


Figura 10: Pirogramas de BRAF, NRAS e KRAS do Caso 14

\begin{tabular}{|c|c|c|c|}
\hline Pirosequenciamento & BRAF & NRAS & KRAS \\
\cline { 2 - 4 } & Códon 600 & Códon 12 e 13 & Códon 12 e 13 \\
\hline
\end{tabular}

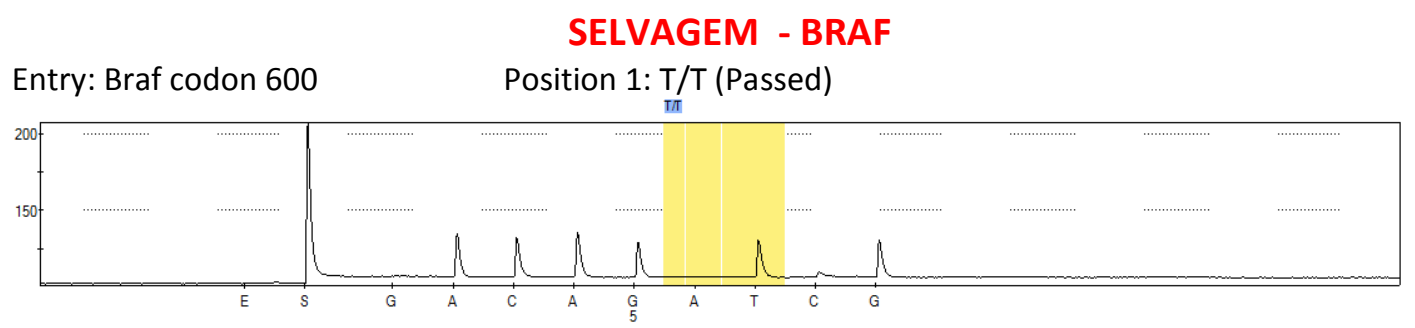

MUTADO CODON $12 \mathrm{G} / \mathrm{T}$ 34\% - NRAS

Entry: NRAS 12-13 Position 1: G/T (Failed), Position 2: G/G (Passed)

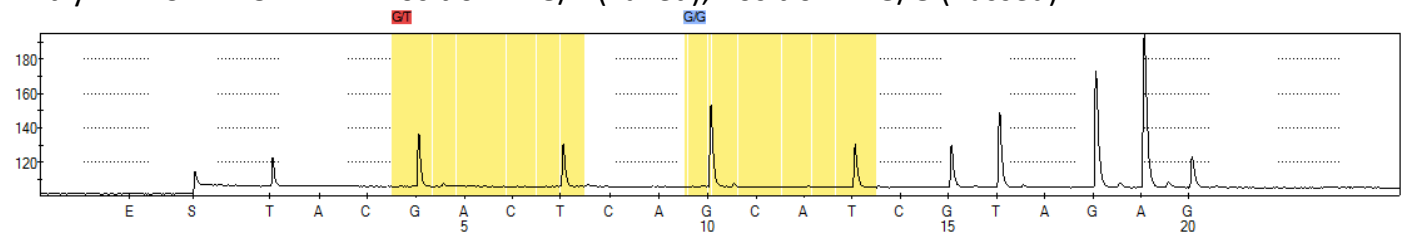

SELVAGEM - KRAS

Entry: KRAS codons 12 e 13 V2.0 Position 1: G/G (Passed), Position 2: G/G (Passed)

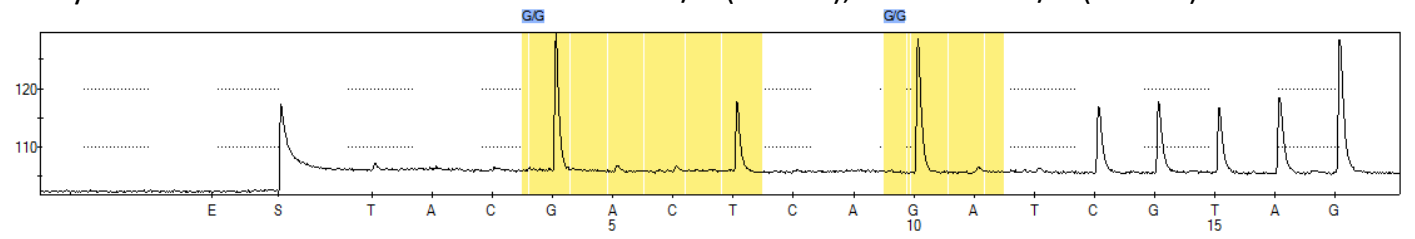


Figura 11: Pirogramas de BRAF, NRAS e KRAS do Caso 17

\begin{tabular}{|c|c|c|c|}
\hline Pirosequenciamento & $\begin{array}{c}\text { BRAF } \\
\text { Códon 600 }\end{array}$ & $\begin{array}{c}\text { NRAS } \\
\text { Códon 12 e 13 }\end{array}$ & $\begin{array}{c}\text { KRAS } \\
\text { Códon } 12 \text { e 13 }\end{array}$ \\
\hline Caso 17 & Selvagem & Mutado & Selvagem \\
\hline
\end{tabular}
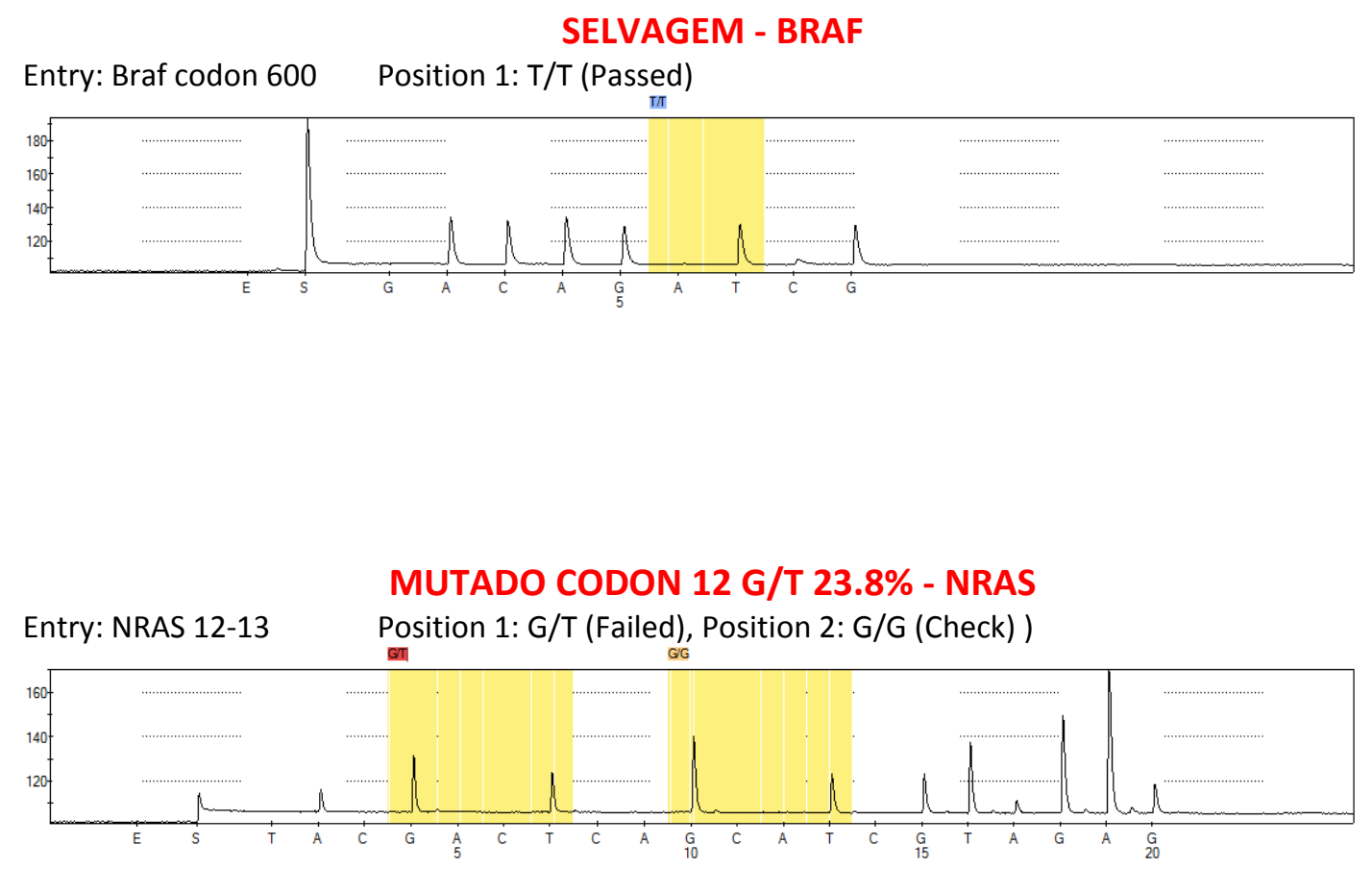

SELVAGEM - KRAS

Entry: KRAS codons 12 e 13 V2.0 Position 1: G/G (Passed), Position 2: G/G (Passed)

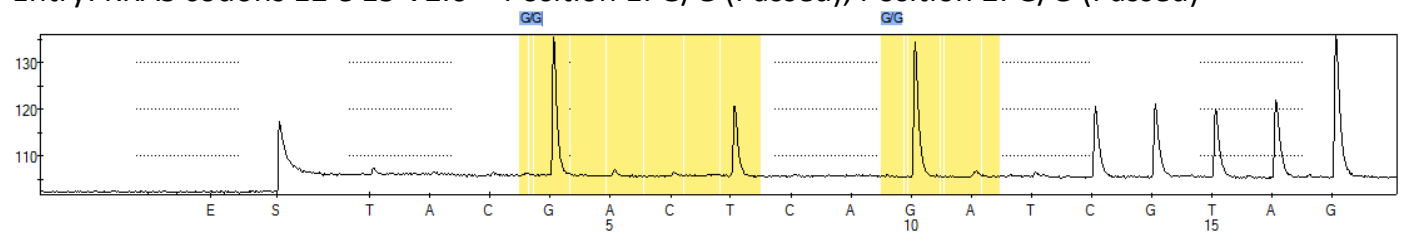


Figura 12: Pirogramas de BRAF, NRAS e KRAS do Caso 18

\begin{tabular}{|c|c|c|c|}
\hline Pirosequenciamento & BRAF & NRAS & KRAS \\
\cline { 2 - 4 } & Códon 600 & Códon 12 e 13 & Códon 12 e 13 \\
\hline Caso 18 & Selvagem & Selvagem & Selvagem \\
\hline
\end{tabular}
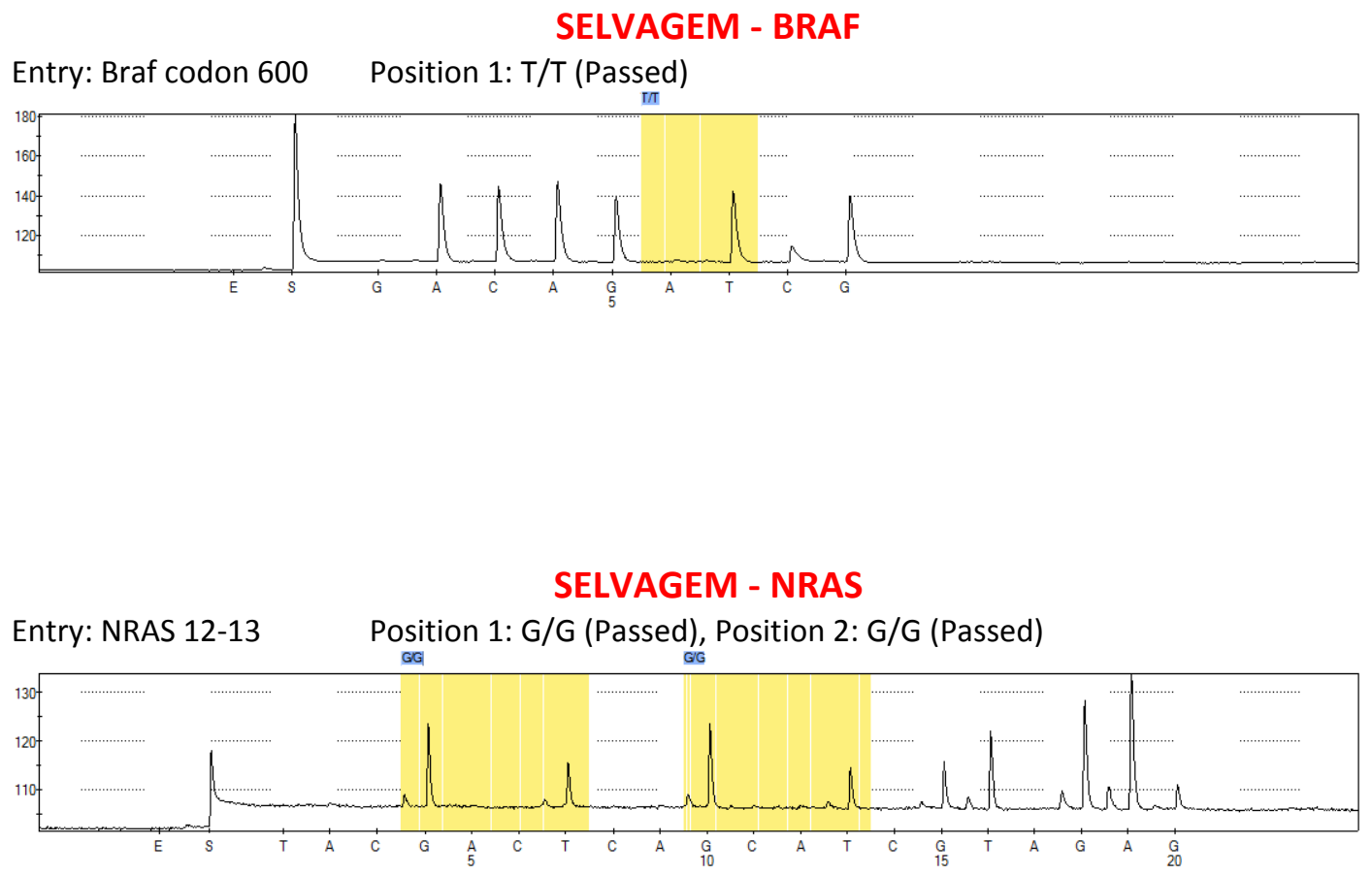

SELVAGEM - KRAS

Entry: KRAS codons 12 e 13 V2.0 Position 1: G/G (Passed), Position 2: G/G (Passed)

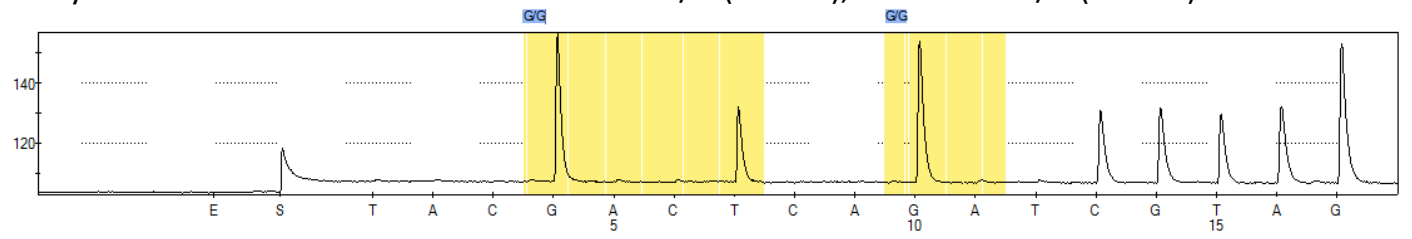


Figura 13: Pirogramas de BRAF, NRAS e KRAS do Caso 19

\begin{tabular}{|c|c|c|c|}
\hline Pirosequenciamento & BRAF & NRAS & KRAS \\
& Códon 600 & Códon 12 e 13 & Códon 12 e 13 \\
\hline Caso 19 & Mutado & Selvagem & Selvagem \\
\hline
\end{tabular}

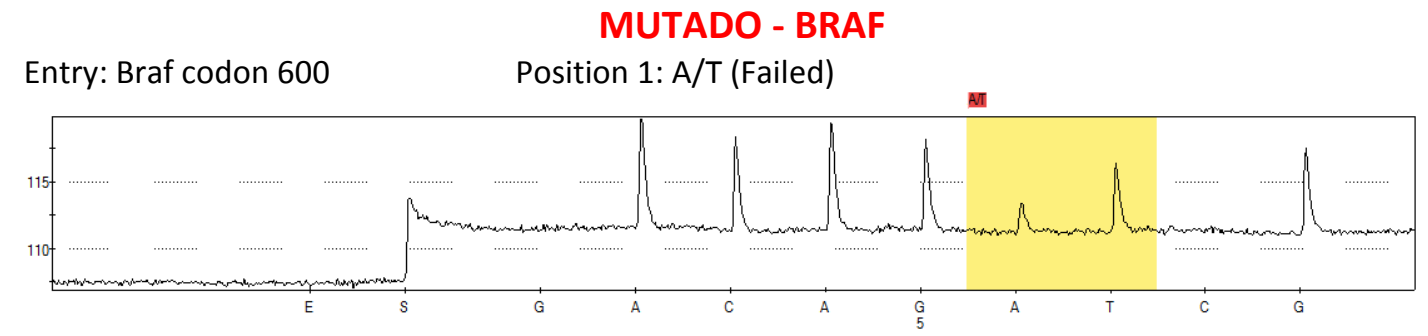

\section{SELVAGEM - NRAS}

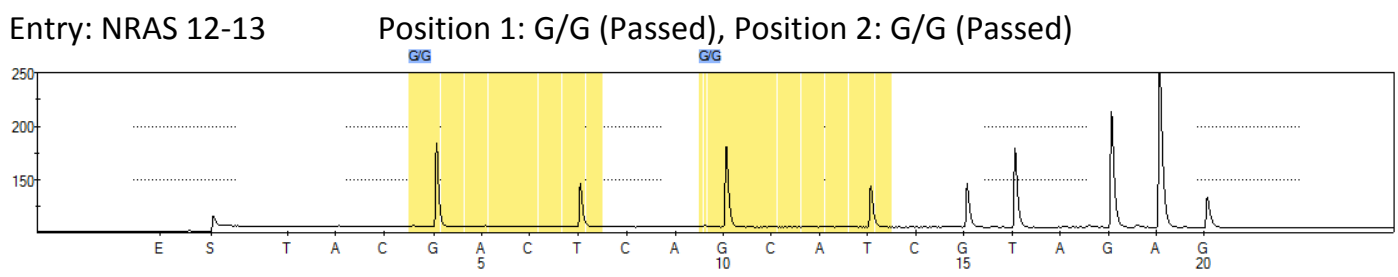

SELVAGEM - KRAS

Entry: KRAS codons 12 e 13 V2.0 Position 1: G/G (Passed), Position 2: G/G (Passed)

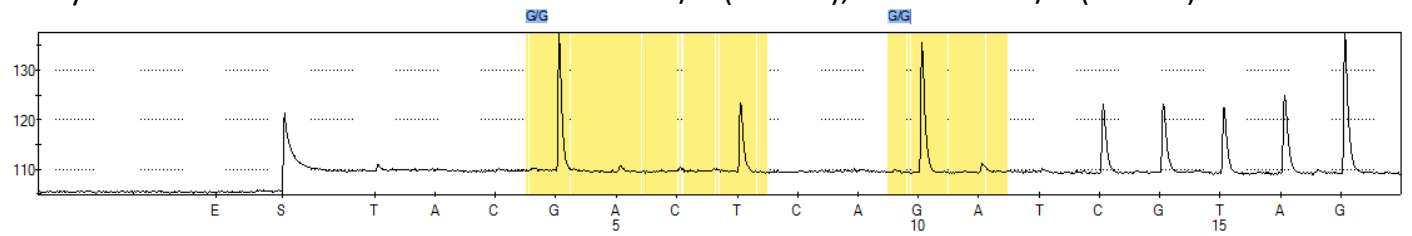


Figura 14: Pirogramas de BRAF, NRAS e KRAS do Caso 23

\begin{tabular}{|c|c|c|c|}
\hline Pirosequenciamento & BRAF & NRAS & KRAS \\
& Códon 600 & Códon 12 e 13 & Códon 12 e 13 \\
\hline Caso 23 & Mutado & Selvagem & Selvagem \\
\hline
\end{tabular}

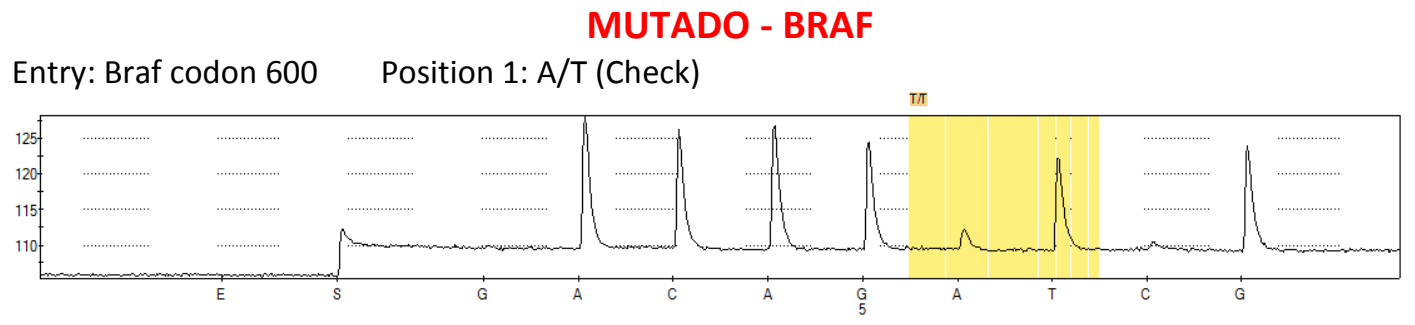

\section{SELVAGEM - NRAS}

Entry: NRAS 12-13 Position 1: G/G (Passed), Position 2: G/G (Passed)

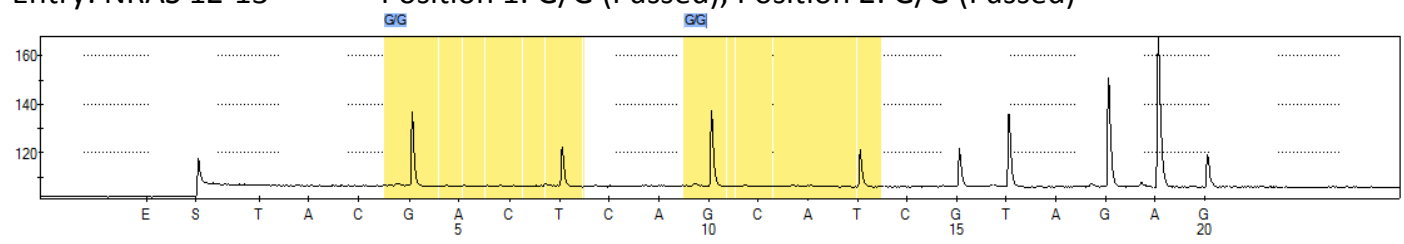

SELVAGEM - KRAS

Entry: KRAS codons 12 e 13 V2.0 Position 1: G/G (Passed), Position 2: G/G (Passed)

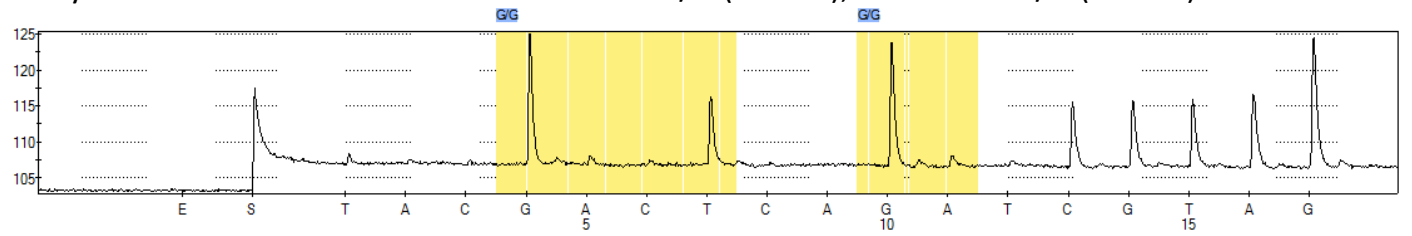


Figura 15: Pirogramas de BRAF, NRAS e KRAS do Caso 25

\begin{tabular}{|c|c|c|c|}
\hline Pirosequenciamento & BRAF & NRAS & KRAS \\
& Códon 600 & Códon 12 e 13 & Códon 12 e 13 \\
\hline Caso 25 & Mutado & Selvagem & Selvagem \\
\hline
\end{tabular}
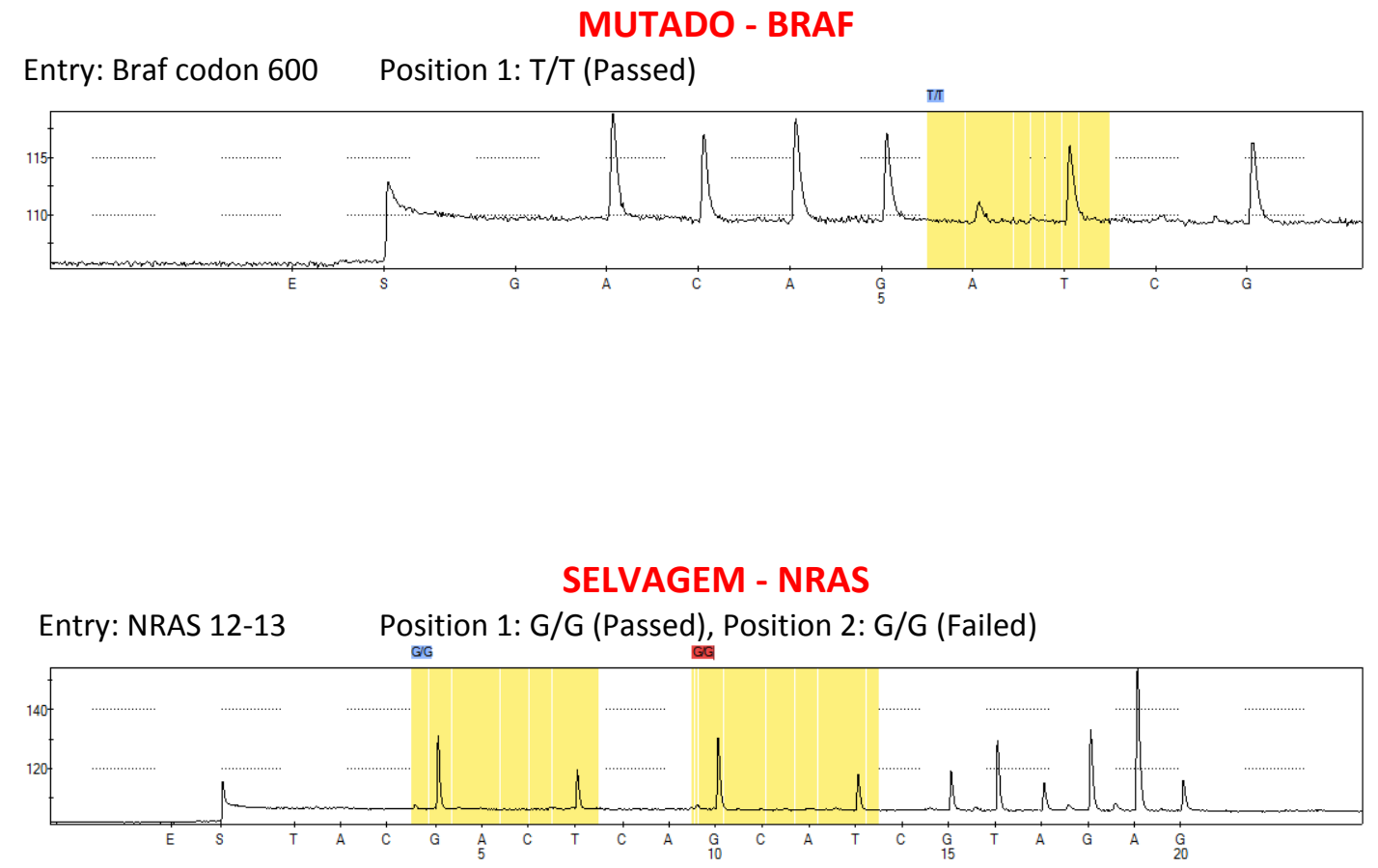

SELVAGEM - KRAS

Entry: KRAS codons 12 e 13 V2.0 Position 1: G/G (Passed), Position 2: G/G (Passed)

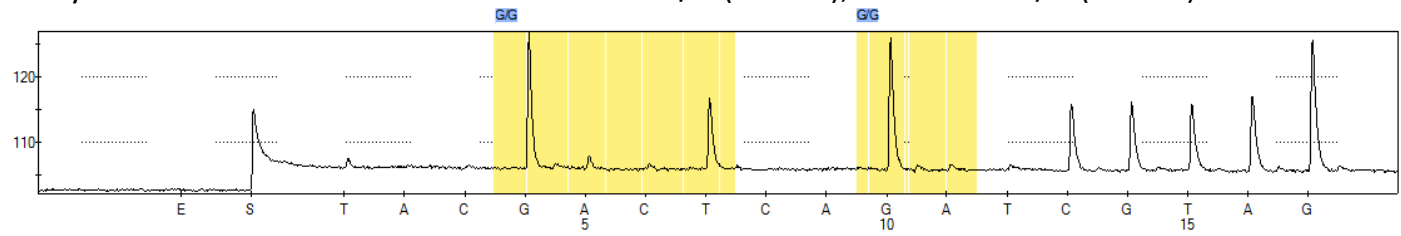


Figura 16: Pirogramas de BRAF, NRAS e /LRAS do Caso 26 (98-10586-a)

\begin{tabular}{|c|c|c|c|}
\hline Pirosequenciamento & BRAF & NRAS & KRAS \\
& Códon 600 & Códon 12 e 13 & Códon 12 e 13 \\
\hline Caso 26 & Selvagem & Selvagem & Selvagem \\
\hline
\end{tabular}
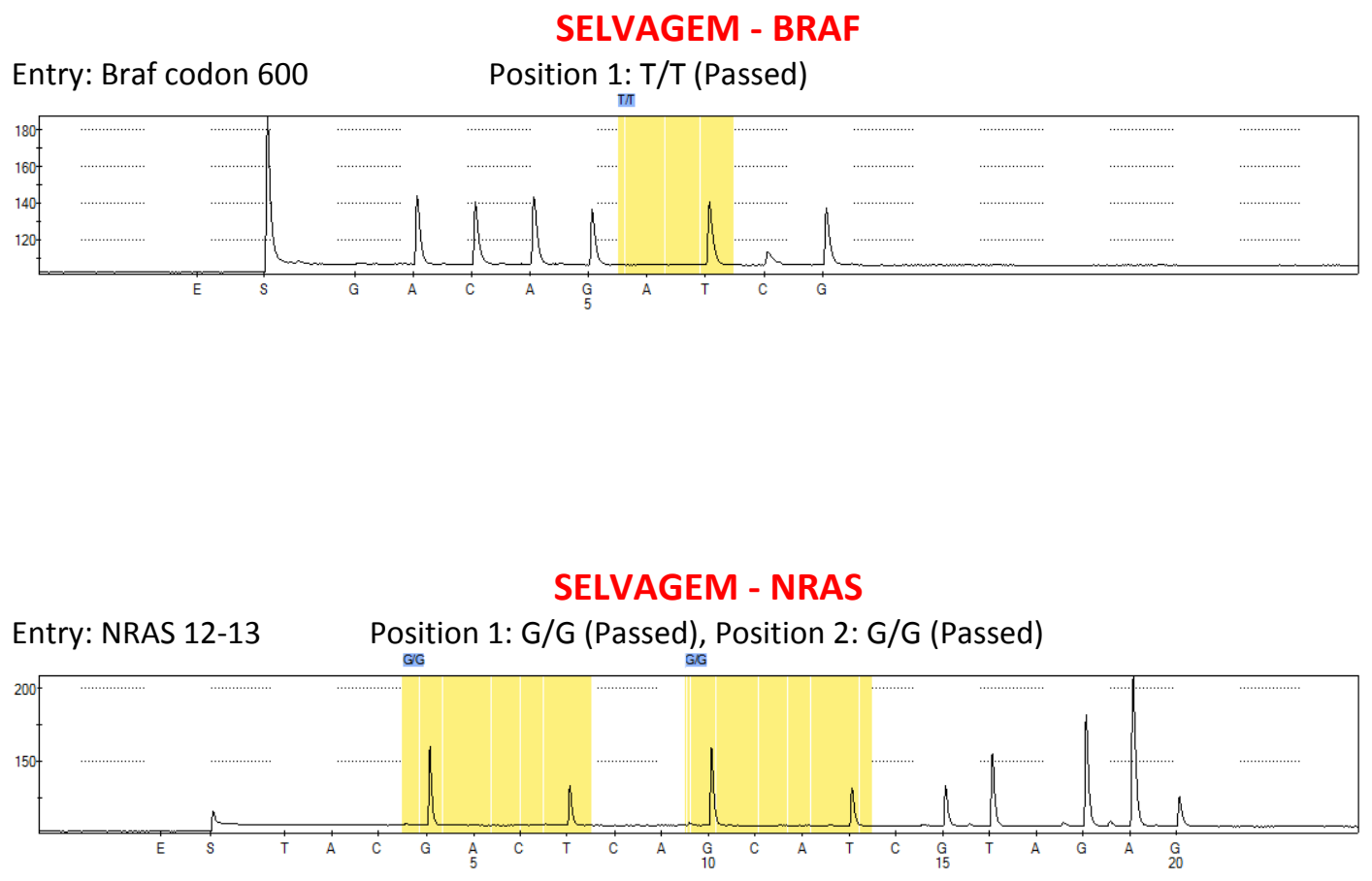

SELVAGEM - KRAS

Entry: KRAS codons 12 e 13 V2.0 Position 1: G/G (Passed), Position 2: G/G (Passed)

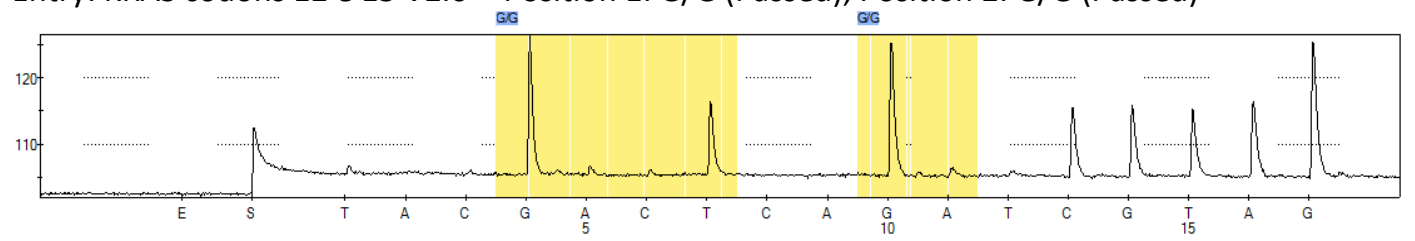


Figura 17: Pirograma de BRAF, NRAS e KRAS do Caso 31 (23962)

\begin{tabular}{|c|c|c|c|}
\hline Pirosequenciamento & $\begin{array}{c}\text { BRAF } \\
\text { Códon 600 }\end{array}$ & $\begin{array}{c}\text { NRAS } \\
\text { Códon 12 e 13 }\end{array}$ & $\begin{array}{c}\text { KRAS } \\
\text { Códon 12 e 13 }\end{array}$ \\
\hline Caso 31 & Selvagem & Selvagem & Selvagem \\
\hline
\end{tabular}
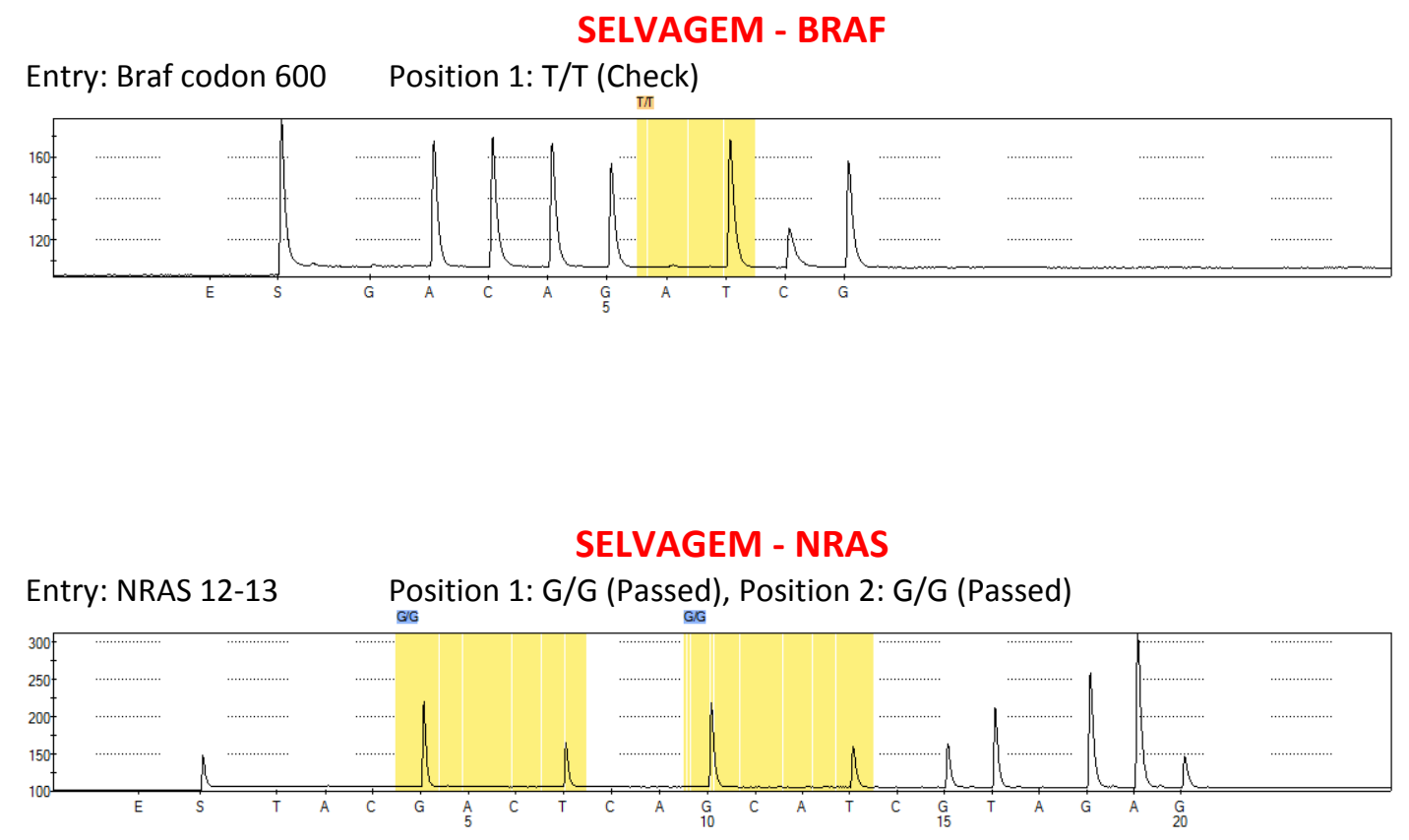

SELVAGEM - KRAS

Entry: KRAS codons 12 e 13 V2.0 Position 1: G/G (Passed), Position 2: G/G (Passed)

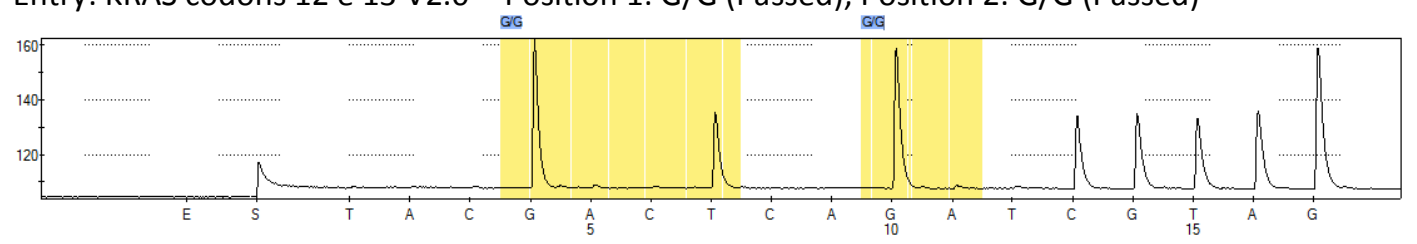


Figura 18: Pirogramas de BRAF, NRAS e KRAS do Caso 35 (MO-01)

\begin{tabular}{|c|c|c|c|}
\hline Pirosequenciamento & BRAF & NRAS & KRAS \\
& Códon 600 & Códon 12 e 13 & Códon 12 e 13 \\
\hline Caso 35 & Mutado & Selvagem & Selvagem \\
\hline
\end{tabular}
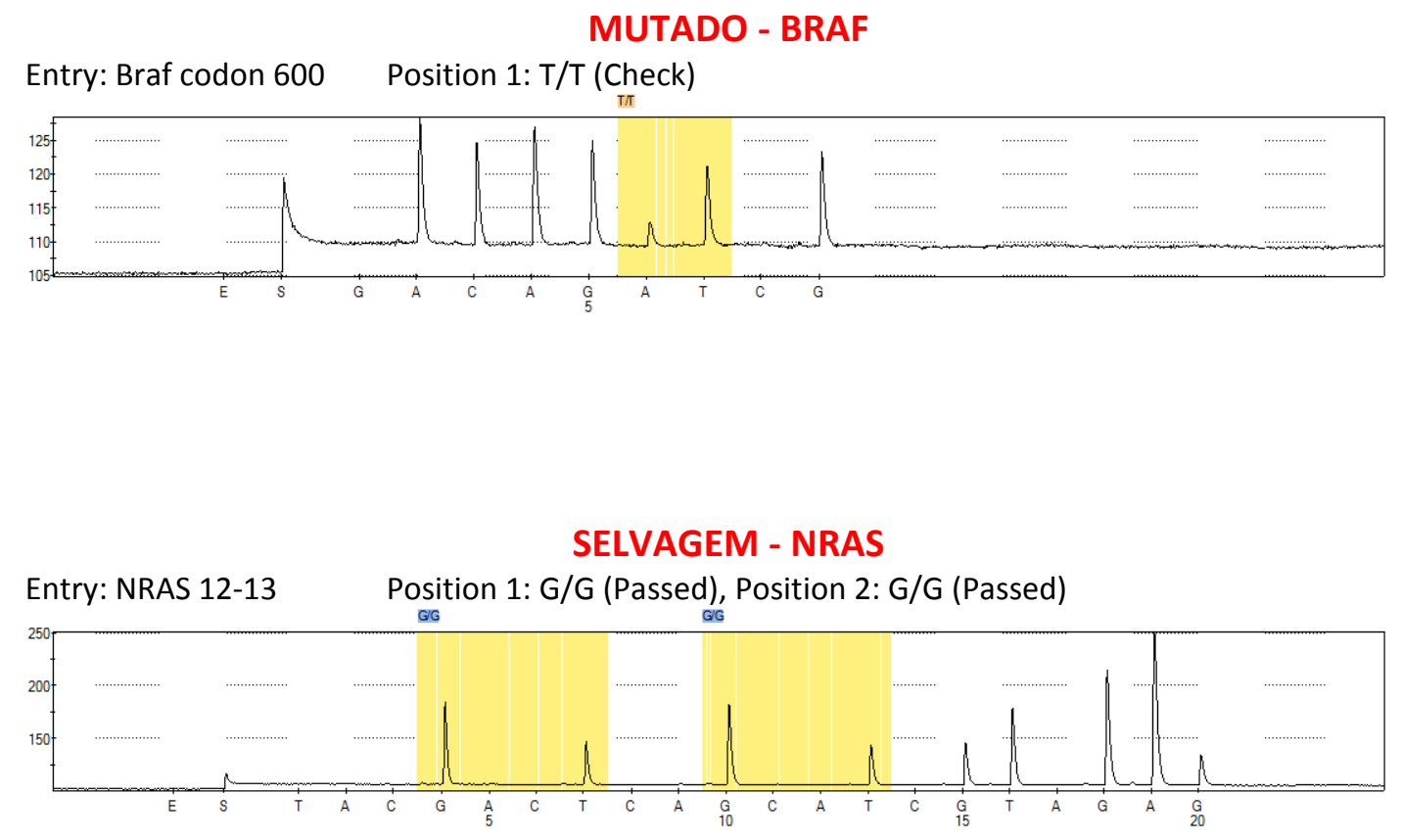

\section{SELVAGEM - KRAS}

Entry: KRAS codons 12 e 13 V2.0 Position 1: G/G (Passed), Position 2: G/G (Passed)

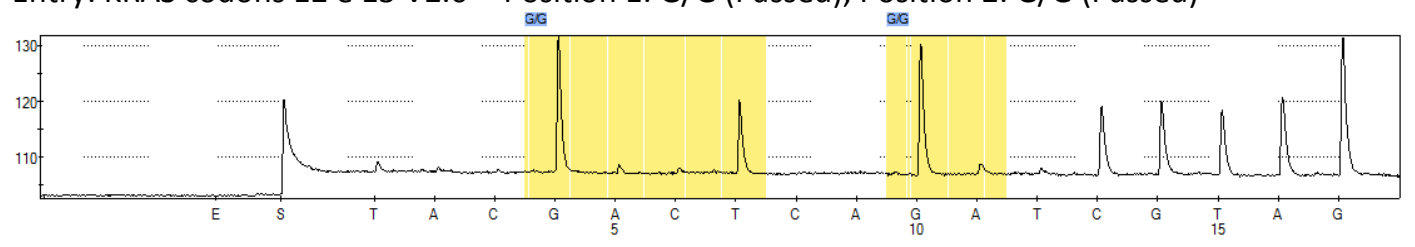


Figura 19: Pirograma de BRAF, NRAS e KRAS dos controles positivos
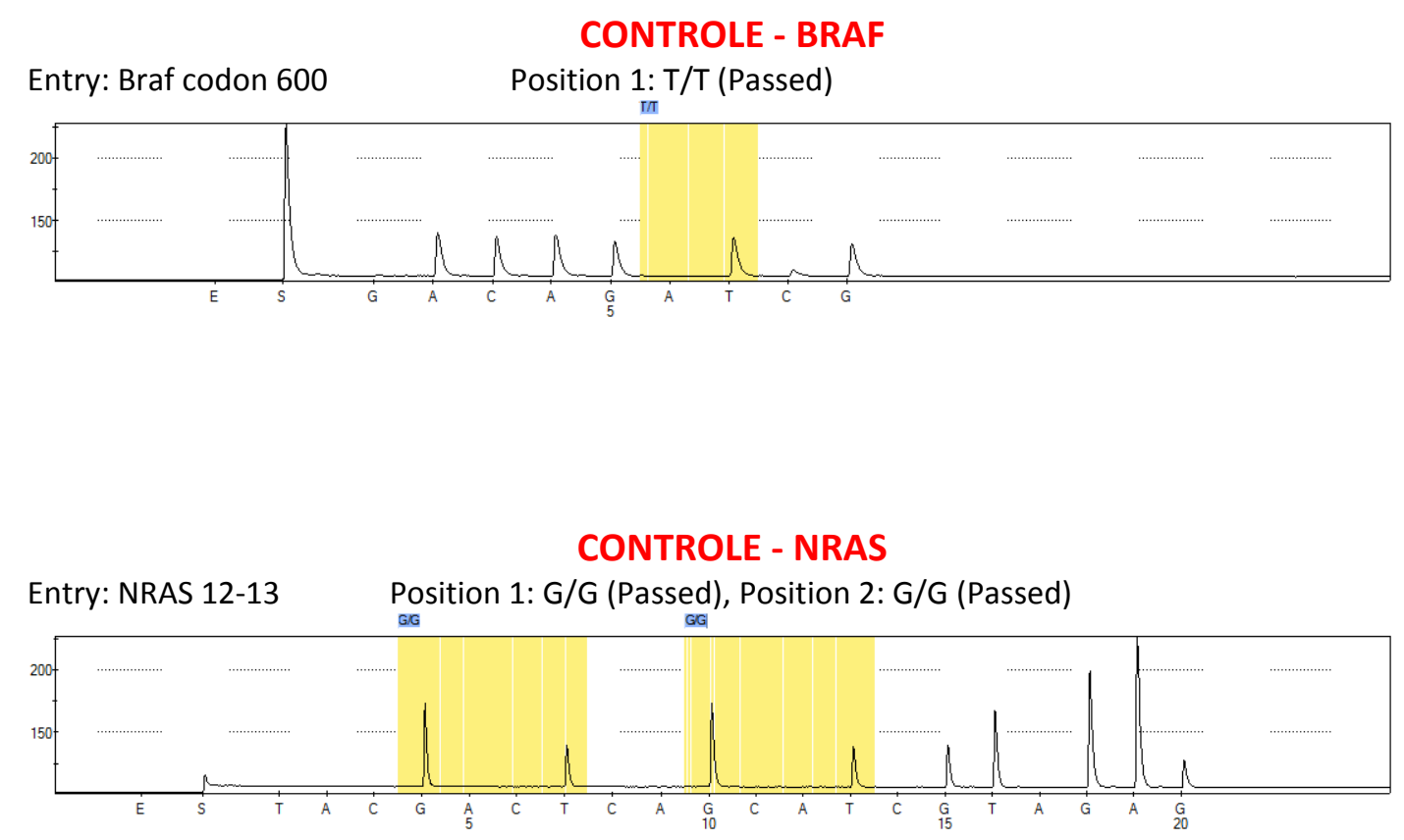

CONTROLE - KRAS

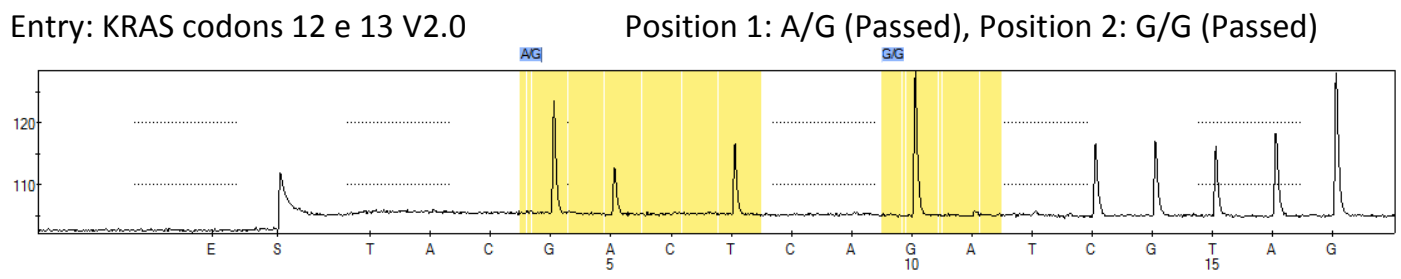




\section{DISCUSSÃO}

A casuística desse estudo retrospectivo compreendeu 35 lesões de melanoma primário da mucosa oral, selecionados dos arquivos da Disciplina de Patologia Geral da Faculdade de Odontologia da Universidade de São Paulo, do Departamento de Dermatologia da Faculdade de Medicina da Universidade de São Paulo e do Departamento de Anatomia Patológica do Hospital do Câncer, Fundação Antonio Prudente, São Paulo, já organizados em forma de matriz (tissue microarray TMA).

No presente estudo encontramos a idade dos pacientes variou entre 9 e 91 anos e a idade média encontrada foi 61 anos ao serem diagnosticados da doença. 0 melanoma primário da mucosa oral pode ocorrer em qualquer faixa etária sendo muito incomum em pessoas abaixo dos 30 anos de idade, geralmente entre 30 e 90 anos, sendo a maior incidência na $6^{\text {a }}$ década de vida (Lee et al., 2002; Aguas et al., 2009; Sortino-Rachou et al., 2009).

Em relação ao gênero, encontramos 18 pacientes masculinos (51,43\%) e 17 femininos (48,57\%). Geralmente não ocorre predileção ao sexo, porém alguns autores referem uma leve predileção pelo sexo feminino, outros referem ao masculino (Aguas et al., 2009).

Segundo dados da literatura, a doença tem sido relatada com maior frequência em asiáticos e negros; isso é atribuído parcialmente pelos comuns achados de pigmentação melânica na mucosa oral dessas raças (Aguas et al., 2009). Nos Estados Unidos, a proporção de melanomas de mucosa é maior $(8,8 \%)$ em afro- 
americanos e hispânicos do que na população em geral (1,3\%), enquanto Japão e Uganda revela-se uma doença relativamente frequente (Lengyel et al., 2003). A incidência do MPMO no Japão é aproximadamente 11 - 24\%, maior do que em países ocidentais (Lee et al., 2002). Na nossa população a doença parece acometer com maior freqüência indivíduos brancos (Lourenço et al., 2009). Observamos neste estudo, maior prevalência dos melanomas para caucasianos (21 pacientes ou 75\%) em relação aos não-brancos (25\%) (5 melanodermas e 2 xantodermas).

A maior parte dos pacientes $(71,42 \%)$ apresentavam lesões no palato, de acordo com outros estudos, os locais de maior ocorrência são o palato e a gengiva superior (80\% dos melanomas orais) (Lourenço et al., 2009). Outras localizações incluem a gengiva inferior, mucosa jugal, língua e soalho bucal (Rapini et al., 1985; Hicks e Flaitz, 2000; Lee et al., 2002; Lengyel et al., 2003; Rapidis et al, 2003; Garzino-Demo et al, 2004; Aguas et al., 2009; Sortino-Rachou et al., 2009 ).

Nesta casuística aspecto histopatológico (grau III) foi encontrado em $80 \%$ dos espécimes e metástases a distância foram relatadas em $60 \%$ dos casos. Estes dados são compatíveis com as características descritas da lesão na literatura. Os melanomas das mucosas da cabeça e pescoço têm comportamento supostamente mais agressivo que os melanomas da pele (Lengyel et al., 2003). Os locais mais comuns de metástases são os linfonodos, fígado e pulmão e acometimento generalizado nas fases avançadas da doença (Garzino-Demo et al., 2004). Ainda, diferentemente dos melanomas cutâneos, os melanomas mucosos exibem uma fase de crescimento vertical agressiva com rápido acometimento da submucosa e pior 
prognóstico. Em nossa experiência, esse tipo de comportamente se dá, em geral pelo retardo do diagnóstico nas fases mais precoces da doença, já que em nosso meio, os melanomas primários da mucosa oral são detectados já em fase avançada sem a detecção da fase superficial (radial) de crescimento.

Recentemente, estudos tentaram entender a patogênese do melanoma combinando a avaliação molecular com técnicas histológicas e epidemiológicas para identificar fatores causais relacionados (Goel et al., 2006; Richmond-Sinclair et al., 2008; Jovanovic et al., 2008; Buery et al., 2011). Eles forneceram evidências convincentes que melanomas cutâneos poderiam se desenvolver através de diferentes vias que dependem não somente a característica constitucional do hospedeiro, assim como ambiente externo, onde ele está exposto (RichmondSinclair et al., 2008).

O presente estudo teve como objetivo de elucidar os componentes da via da MAPK, através da análise da expressão proteica dos componentes da via MAPK estudada foi semi-quantitativa e a análise molecular dos genes BRAF; NRAS e KRAS nos casos de melanomas primários da mucosa oral, cujos resultados foram realizados por dois pesquisadores, e correlacionados com os aspectos clínicohistopatológico dos casos selecionados através do teste exato de Fisher.

\section{RAS}

Os genes RAS são os genes mais frequentemente mutados em cânceres humanos, porém diferentes neoplasias mostram frequências e espectro de 
mutações diferentes em NRAS, HRAS e KRAS, membros da superfamília RAS (Haluska et al., 2006; Jarell et al., 2007).

As mutações de NRAS estão presentes em apenas 14\% de melanomas nãocutâneos (incluindo cérebro, uveal) (Fecher et al., 2008). Segundo a literatura, mutações do NRAS são raros em nevos displásicos, ativação do HRAS é comumente associado ao nevo Spitz, enquanto que mutações do KRAS não tem sido descrito em lesões melanocíticas humanas (Chin et al., 2006; Ghosh e Chin, 2009).

De acordo com alguns estudos mais recentes, os melanomas humanos carregam mutações quase exclusivamente no NRAS, aproximadamente, $80-90 \%$ delas localizadas no códon 61, sendo HRAS e KRAS menos mutados (Edlundh-Rose et al., 2006; Haluska et al., 2006; Dahl e Guldberg, 2007; Jarell et al., 2007; Jovanovic et al., 2008).

A expressão de RAS foi positivo para $28,57 \%$ nos casos estudados, foi expresso tanto in situ como em melanoma da mucosa oral, com padrão semelhante ao observado pelo Buery et al., 2011. A marcação foi localizada na membrana celular e no citoplasma. Muitos casos apresentaram expressão negativa da proteína RAS em lesões com metástase distante (16/21), em tumores com grau histológico II e III (4/6 e 18/21, respectivamente) e em lesões com invasão vascular (14/20).

Foi observado mutação do códon 12 do gene NRAS em apenas dois casos (2/14), onde ocorreu a incorporação de $T$ no lugar de $G(G>T)$ na posição 1 , enquanto que nenhum paciente apresentou mutação no gene KRAS em ambos os códons. Estes resultados estão de acordo com os dados encontrados na literatura, 
pois mutação em RAS, principalmente NRAS, é encontrada em melanomas cutâneos e não-cutâneos, alguns autores relacionam a presença da mutação com sítios expostos à radiação UV, porém os melanomas primários da mucosa oral são de áreas foto-protegidas.

BRAF

Desde a descoberta através do programa de sequenciamento amplo do genoma do câncer (exemplo: Sanger Institute's Cancer Genome Project), mutações do BRAF foram encontradas em uma variedade de tumores com a maior incidência em melanoma (variando de 27 a 70\%), seguido pelo carcinoma papilífero da tireóide, carcinomas do cólon e de ovário (Chin et al., 2006; Dahl e Guldberg, 2007; Jarell et al., 2007). Segundo Haluska et al., 2006, a mais importante mutação já descoberta em melanomas ocorre no BRAF.

As mutações em BRAF são notadas em mais de $80 \%$ dos casos de melanoma cutâneo primário, ele também está mutado na maioria dos casos de nevo melanocítico benigno e displásico, sugerindo que ele representa um dos primeiros eventos na neoplasia melanocítica (Goel et al., 2006; Dahl e Guldberg, 2007; Palmieri et al., 2007; Ghosh e Chin, 2009). Esses nevos muitas vezes permanecem em crescimento vida interrompida e raramente progride para melanoma. Isso sugere que BRAF ${ }^{\mathrm{V} 600 \mathrm{E}}$ promove um ponto de checagem para transformação maligna (Ghosh e Chin, 2009). 
Especificamente, as mutações BRAF são comuns em melanomas cutâneos decorrentes à exposição solar intermitente (59\%), como tronco e braços, comparados com somente $23 \%$ de melanomas acrais e $11 \%$ de melanomas das mucosas, porém ausente em melanoma uveal (Chin et al., 2006).

A mutação mais comum em BRAF, a qual contabiliza mais de $90 \%$ dos casos de câncer envolvendo este gene, é a substituição de acido glutâmico para valina na posição 600 (V600E), classicamente não esta associada à danos induzidos por UV (Turner et al., 2005; Chin et al., 2006; Thomas, 2006; Dahl e Guldberg, 2007; Dhomen e Marais, 2007; Palmieri et al., 2007; Halilovic e Solit, 2008; Jovanovic et al., 2008; Ghosh e Chin, 2009; Smalley, 2010 ).

Neste estudo a proteína BRAF foi superexpressa na maioria dos casos (82,85\%). A expressão de BRAF foi essencialmente citoplasmática e foi expressa em todos os tumores melanocíticos com coloração de intensidade variável. BRAF pode ser expresso na epiderme, glândulas sebáceas, fibroblastos e endotélio de forma difusa ou tênue, mas em melanoma ele apresenta uma marcação mais difusa e intensa (Uribe et al., 2006). A maioria dos casos deste estudo apresentou expressão positiva de BRAF em lesões com metástase a distância (17/21), em tumores de grau histológico II e III (6/6 e 22/27, respectivamente) e em lesões com invasão vascular (18/20). Quanto à análise molecular, foram observados mutação no códon 600 do gene BRAF em 9 casos (9/14), onde ocorreu a incorporação de A no lugar de $T$ (T>A).

A mutação de BRAF é observada em $80 \%$ dos melanomas cutâneos primários, mas também está mutado na maioria dos nevos melanocíticos benignos, 
e muitos deles progridem para melanoma (Goel et al., 2006). A presença de mutação em BRAF em nevo fortemente sugere que a ativação de BRAF é necessária, mas não suficiente para desenvolver o melanoma (Palieri et al., 2009). De acordo com Uribe et al. (2006), a ausência da ativação da MAPK na presença de mutação de BRAF, especialmente em nevo congênito e nevo atípico, não pode ser explicado pela ausência da expressão de BRAF ou ERK1/2 total, mas pela existência de mecanismos que induzem a ativação da via e/ou mecanismos inibitórios que reduzem a expressão ou ativação da proteína BRAF ou outras proteínas associadas à ativação das fosfatases da MAPK e inibidores de quinases RAF (Uribe et al., 2006).

Alguns estudos relatam que mutações em BRAF são as mais comuns dentre os melanomas decorrentes de sítios onde a pele não está cronicamente exposta ao sol. A frequência de mutações é baixa em aras anatômicas que recebem menos exposição solar. Há uma evidência crescente que mutações em BRAF são eventos iniciais no desenvolvimento do melanoma, e que pode surgir através da reparação incorreta do DNA seguindo a formação de fotoproduto induzido pela radiação UV (Moldonado et al., 2003; Richmond-Sinclair et al., 2008).

Estes resultados estão de acordo com aqueles encontrados na literatura, pois além ocorrer a mutação de BRAF na maioria dos melanomas cutâneos, principalmente referindo à substituição de acido glutâmico para valina na posição 600 (V600E), classicamente não esta associada à danos induzidos por UV, e o MPMO são lesões que ocorrem numa áreas fotoprotegidas. 
MEK

No presente estudo, MEK1 não foi expresso em todos os casos, enquanto MEK 2 apresentou expressão com padrão citoplasmático em 51,43\% dos casos, sendo esta associada estatisticamente com invasão vascular $(p=0.043)$. A sobreposição e função única das isoformas de cada nível da via de sinalização RAS/RAF/MEK/ERK estão apenas começando a serem elucidadas. Frequentemente, não há distinção entre as funções de MEK1 e MEK2 ou ERK1 ou ERK2, e poucos estudos têm examinado a contribuição individual de cada isoforma para processos biológicos. Está claro em estudos genéticos anteriores que MEK1 e MEK2 são funcionalmente redundantes em alguns contextos (Scholl et al., 2009). Por outro lado, de acordo com Emery et al.(2009), se a dependência de MEK observada em melanoma BRAF-mutado está presente em outros contextos orientados por MAPK permanece uma questão aberta. Estudos pré-clínicos sugerem que alguns melanomas NRAS-mutado podem também exibir sensibilidade para inibição de RAF ou MEK (Emery et al., 2009). Esta evidencia ainda não foi estudada em melanomas de mucosas.

ERK

ERK regula funções celulares essenciais como proliferação, diferenciação, sobrevivência da célula e morte celular. ERK é ativado por inúmeros agentes extracelulares como fatores de crescimento, citocinas, hormônios e promotores de tumor (Mirmohammadsadegh et al., 2007). 
Em células BRAF ou NRAS tipo selvagem, a ativação do ERK é bastante baixa comparada com células mutantes e pode controlar proteínas envolvidas na aderência extracelular, motilidade celular e angiogênese. Nos melanomas, ERK pode inibir regulador do ciclo celular p2 $7^{\mathrm{kip} 1}$, pode também alterar in vitro a capacidade de invasão pela regulação da produção de metaloproteinase-1, entretanto pode também regular sobrevivência e senescência (Ghosh e Chin, 2009).

Em melanoma, a atividade do ERK tem sido aumentada nos estágios iniciais até os avançados da doença. Uma hipótese atrativa é que a mutagênese de NRAS ou BRAF, a qual ocorre anteriormente ao ERK, é primariamente responsável pela ativação do ERK observada. Entretanto, mutação de BRAF tem sido relatada em nevos e ERK ainda é ativada somente na minoria desses espécimes, outro mecanismo regulador deve ser no lugar de minimizar estimulação da MAPK indesejada.

Forte evidência apoia o argumento de que mutações do BRAF oncogênicas acontecem na superativação de MEK/ERK, o qual mantém o fenótipo transformado em melanoma maligno (Jarell et al., 2007). Mirmohammadsadegh et al. (2007), observou a ativação de ERK1/2 em 54\% de melanomas primários por imunoistoquímica. Em algumas pesquisas, a ativação de ERK tem sido reportado 54$100 \%$ dos melanomas primários, sendo que uma pesquisa mostra que $93 \%$ dos melanomas primários com mutações do BRAF no códon 600 tem ativado o ERK. Alguns autores associam a ativação de MEK/ERK com melanomas BRAF mutados (Jovanovic et al., 2008). 
Entretanto, estudos anteriores também identificaram um subgrupo de melanomas sem mutação em genes NRAS e BRAF, o qual foi especulado que a ativação de ERK ocorre através de efetores não identificados anteriormente (Jovanovic et al., 2008).

Em nosso estudo, notamos que ERK1 apresentaram uma regulação descendente (downregulated) ( $80 \%$ dos casos foram negativos). Foi observada a expressão negativa de ERK1 em lesões com metástase distante (18/21), em tumores de grau histológico II e III (4/5 e 21/27, respectivamente) e em lesões com invasão vascular (18/20). Entretanto, ERK2 foi superexpresso na maioria dos casos $(74,28 \%)$, e foi observada a expressão positiva de ERK2 em lesões com metástase distante (18/21), em tumores com grau histológico II e III (3/4 e 22/27, respectivamente) e en kesões com invasão vascular (17/20). O padrão de imunomarcação observado foi predominantemente citoplasmático, e nuclear em poucos casos quando estava presente. De acordo com Houben et al. (2008), eles observaram que aproximadamente $50 \%$ das amostras analisadas foram caracterizadas pela quase completa ausência de fosforilação de ERK em células tumorais. Embora, em tumores com falta de células tumorais fosfo-ERK positivas, eles detectaram células do estroma fosfo-ERK positivas (como endotélio e macrófagos), servindo de controle positivo interno. Notavelmente a falta de fosforilação de ERK não foi devido à baixa expressão da proteína ERK, como coloração para ERK1/2 total em melanomas primários e metastáticos, geralmente, demonstrava que expressão forte e homogeneamente (Houben et al., 2008). Em outro estudo de expressão de 
proteínas ERK1/2 por imunoistoquímica mostrou pouca marcação em nevo (5-10\% de células positivas), independente da presença de mutação de BRAF. Por outro lado, os melanomas por eles estudados, geralmente apresentava forte expressão de ERK $1 / 2$ (50-70\% células positivas), porém esta marcação não estava relacionada com a presença de mutação de BRAF (Venesio et al., 2008). Além disso, a análise multivariada apresentou a ausência de ativação citoplasmática de ERK foi marcador de prognóstico independente desfavorável, opondo aos resultados que mostraram sem impacto na expressão da proteína ERK em sobreviventes.

Pode-se especular que as diferentes isoformas de ERK (ERK1 e ERK2) podem sugerir funções opostas. Recentemente, um estudo avaliou alguns modelos nãomelanoma, cuja proliferação induzida por RAS tem sido associado à expressão de ERK2, enquanto que ERK1 tem sido proposto de desempenhar um papel de regulador antagonista da atividade de ERK2 (Jovanovic et al., 2008). 


\section{CONCLUSÕES}

1. Observamos importante expressão proteica na maioria dos casos para BRAF e ERK2, enquanto que RAS, MEK2 e ERK1 apresentaram expressão na minoria dos casos e MEK1 apresentou expressão negativa em todos os casos analisados. Dessa maneira, conclui-se que existem alterações dos componentes desta via, indicando participação deles na patogenia dos melanomas primários da mucosa oral.

2. Os 9 casos que apresentaram mutação no códon 600 do BRAF, não apresentaram mutação nos códons 12 e 13 de NRAS, ao mesmo tempo, os 2 casos que apresentaram mutação na posição 1 do códon 12 de NRAS, não apresentaram mutação para BRAF, demonstrando dessa maneira que são eventos independentes. Enquanto a ausência de mutação em ambos os códons do gene KRAS, indica que ele não participa da patogenia dos melanomas primários da mucosa oral.

3. BRAF e ERK2 foram correlacionados com alto grau histológico, invasão vascular e metástase a distância. Adicionalmente a expressão de MEK2 foi estatisticamente significante ao correlacionar com a invasão vascular $(p=$ 0,043). 
Todos os aspectos da via MAPK necessita de outras elucidações em melanomas de áreas foto-protegidas e melanomas de mucosa e comparando diferentes populações. Entretanto, os resultados deste presente estudo apontam importante alterações na cascata RAS-RAF-MEK-ERK e estes são indicadores de prognóstico ruim em melanomas primários da mucosa oral, independente da exposição solar. 


\section{REFERÊNCIAS BIBLIOGRÁFICAS}

Aguas SC, Quarracino MC, Lence AN, Lanfranchi-Tizeira HE. Primary melanoma of the oral cavity: ten cases and review of 177 cases from literature. Med Oral Patol Oral Cir Bucal. 2009 Jun 1;14(6):E265-271.

Barker BF, Carpenter WM, Daniels TE, Kahn MA, Leider AS, Lozada-Nur F, Lynch DP, Melrose R, Merrell P, Morton T, Peters E, Regezi JA, Richards SD, Rick GM, Rohrer MD, Slater L, Stewart JC, Tomich CE, Vickers RA, Wood NK, Young SK. Oral mucosal melanomas: the WESTOP Banff workshop proceedings. Oral Surg Oral Med Oral Pathol Oral Radiol Endod. 1997 Jun; 83(6): 672-679.

Balch CM, Wilkerson JA, Murad TM, Soong SJ, Ingalls AL, Maddox WA. The prognostic significance of ulceration of cutaneous melanoma. Cancer. 1980 Jun 45(12): 3012-3017.

Breslow A. Thickness, cross-sectional areas and depth of invasion in the prognosis of cutaneous melanoma. Ann Surg. 1970 Nov; 172 (5): 902-908.

Buery RR, Siar CH, Katase N, Gunduz M, Lefeuvre M, Fujii M, Inoue M, Setsu K, Nagatsuka H. NRAS and BRAF mutation frequency in primary oral mucosal melanoma. Oncol Rep. 2011 Oct;26(4):783-7. doi: 10.3892/or.2011.1385. Epub 2011 Jul 11. 
Carlson JA, Ross JS, Slominski A, Linette G, Mysliborski J, Hill J, Mihm M Jr. Molecular diagnostics in melanoma. J Am Acad Dermatol. 2005 May;52(5):743-75; quiz 775778.

Chidzonga MM, Mahomva L, Marimo C, Makunike-Mutasa R. Primary malignant melanoma of the oral mucosa. J Oral Maxillofac Surg. 2007 Jun; 65(6):117-120.

Chin L, Merlino G, DePinho RA. Malignant melanoma: modern black plague and genetic black box. Genes Dev. 1998 Nov 15;12(22):3467-3481.

Chin L, Garraway LA, Fisher DE. Malignant melanoma: genetics and therapeutics in the genomic era. Genes Dev. 2006 Aug 15;20(16):2149-2182.

Chudnovsky Y, Khavari PA, Adams AE. Melanoma genetics and the development of rational therapeutics. J Clin Invest. 2005 Apr;115(4):813-824.

Clark WH Jr, From L, Bernadino EA, Mihm MC. Histogenesis and biologic behaviour of primary human malignant melanomas of the skin. Cancer Res. 1969 Mar; 29(3): 705-726.

Clark WH Jr, Elder DE, Guerry D IV. Dysplasic nevi and malignant melanoma. In: Farmer ER, Hood AF, eds. Pathology of the skin. East Norwalk, Connecticut: Appleton \& Lange, 1990: p.682-754. 
Dahl C, Guldberg P. The genome and epigenome of malignant melanoma. APMIS. 2007 Oct;115(10):1161-1176.

Davis NC, McLeod GR. From Hunter to Handley (1787-1907). A retrospective on management approaches to melanoma. In: Cutaneous melanoma. Blach CM, Houghton AN, Sober AJ, Soong SJ, editors. $3^{\text {rd }}$ ed, QMP, St Louis, Missoury, 1998. p. 1-8.

Day CL Jr, Harrist TJ, Gorstein F, Sober AJ, Lew RA, Friedman RJ, Pasternack BS, Kopf AW, Fitzpatrick TB, Mihm MC Jr. Malignant melanoma. Prognostic significance of "microscopic satellites" in the reticular dermis and subcutaneous fat. Ann Surg. 1981 Jul; 194(1): 108-112.

Day CL, Harrist TJ, Lew RA, Mihm MC Jr. Classification of malignant melanomas according to the histologic morphology of melanomas nodules. J Dermatol Surg Oncol. 1982a Oct; 8(10): 874-875.

Day CL Jr, Lew RA, Mihm MC Jr, Sober AJ, Harris MN, Kopf AW, Fitzpatrick TB, Harrist TJ, Golomb FM, Postel A, Hennessey P, Gumport SL, Raker JW, Malt RA, Cosimi AB, Wood WC, Roses DF, Gorstein F, Rigel D, Friedman RJ, Mintzis MM, Grier RW.A multivariate analysis of prognostic factors for melanoma patients with lesions greater than or equal to $3.65 \mathrm{~mm}$ in thickness. The importance of revealing alternate Cox models. Ann Surg. 1982b Jan; 195(1): 44-49. 
Day CL Jr, Mihm MC Jr, Lew RA, Harris MN, Kopf AW, Fitzpatrick TB, Harrist TJ, Golomb FM, Postel A, Hennessey P, Gumport SL, Raker JW, Malt RA, Cosimi AB, Wood WC, Roses DF, Gorstein F, Rigel D, Friedman RJ, Mintzis MM, Sober AJ. Prognostic factors for clinical stage I melanoma of intermediate thickness (1.51-3.39 mm). A conceptual model for tumor growth and metastasis. Ann Surg. 1982c Jan; 195(1): 35-43.

Day CL Jr, Mihm MC Jr, Sober AJ, Harris MN, Kopf AW, Fitzpatrick TB, Lew RA, Harrist TJ, Golomb FM, Postel A, Hennessey P, Gumport SL, Raker JW, Malt RA, Cosimi AB, Wood WC, Roses DF, Gorstein F, Rigel D, Friedman RJ, Mintzis MM. Prognostic factors for melanoma patients with lesions $0.76-1.69 \mathrm{~mm}$ in thickness. Ann Surg. 1982d Jan; 195(1): 30-34.

Dhomen N, Marais R. New insight into BRAF mutations in cancer. Curr Opin Genet Dev, 2007; 17(1):31-93.

Edlundh-Rose E, Egyházi S, Omholt K, Månsson-Brahme E, Platz A, Hansson J, Lundeberg J. NRAS and BRAF mutations in melanoma tumours in relation to clinical characteristics: a study based on mutation screening by pyrosequencing. Melanoma Res. 2006 Dec;16(6):471-478.

Elder DE, Murphy GF. Atlas of tumor pathology. Melanocytic tumors of the skin. Third series. Fascicle 2. 1991: 103-205. 
Emery CM, Vijayendran KG, Zipser MC, Sawyer AM, Niu L, Kim JJ, Hatton C, Chopra R, Oberholzer PA, Karpova MB, MacConaill LE, Zhang J, Gray NS, Sellers WR, Dummer R, Garraway LA. MEK1 mutations confer resistance to MEK and B-RAF inhibition. Proc Natl Acad Sci U S A. 2009 Dec 1;106(48):20411-20416.

Fecher LA, Amaravadi RK, Flaherty KT. The MAPK pathway in melanoma. Curr Opin Oncol 2008; 20(2):183-189.

Femiano F, Lanza A, Buonaiuto C, Gombos F, Di Spirito F, Cirillo N. Oral malignant melanoma: a review of the literature. J Oral Pathol Med. 2008 Aug;37(7):383-388.

Garzino-Demo P, Fasolis M, Maggiore GM, Pagano M, Berrone S. Oral mucosal melanoma: a series of case reports. J Cranio Maxillofac Surg. 2004 Aug; 32(4): 251257.

Ghosh P, Chin L. Genetics and genomics of melanoma. Expert Rev Dermatol. 2009 Apr 1;4(2):131 (1-21).

Goel VK, Lazar AJ, Warneke CL, Redston MS, Haluska FG. Examination of mutations in BRAF, NRAS, and PTEN in primary cutaneous melanoma. J Invest Dermatol. 2006 Jan;126(1):154-60.

Gray-Schopfer VC, Cheong SC, Chong H, Chow J, Moss T, Abdel-Malek ZA, Marais R, 
Wynford-Thomas D, Bennett DC. Cellular senescence in naevi and immortalisation in melanoma: a role for p16? Br J Cancer. 2006 Aug; 95(4): 496-505.

Gu GM, Epstein JB, Morton TH Jr. Intraoral melanoma: long-term follow-up and implication for dental clinicians. A case report and literature review. Oral Surg Med Oral Pathol Oral Radiol Endod. 2003 Oct;96(4):404-13.

Halilovic E, Solit DB. Therapeutic strategies for inhibiting oncogenic BRAF signaling. Curr Opin Pharmacol 2008; 8(4):419-426.

Haluska FG, Tsao H, Wu H, Haluska FS, Lazar A, Goel V. Genetic alterations in signaling pathways in melanoma. Clin Cancer Res. 2006 Apr 1;12(7 Pt 2):2301s2307s.

Harrist TJ, Rigel DS, Day CL Jr, Sober AJ, Lew RA, Rhodes AR, Harris MN, Kopf AW, Friedman RJ, Golomb FM, et al. "Microscopic satellites” are more highly associated with regional lymph nodes metastases than is primary melanoma thickness. Cancer. 1984 May; 53(10): 2183-2187.

Hicks MJ, Flaitz CM. Oral mucosal melanoma: epidemiology and pathobiology. Oral Oncol. 2000 Mar; 36(2): 152-169.

Houben R, Becker JC, Kappel A, Terheyden P, Bröcker EB, Goetz R, Rapp UR. Constitutive activation of the Ras-Raf signaling pathway in metastatic melanoma is associated with poor prognosis. J Carcinog, 2004; 26;3(1): 6 (1-13). 
Jarell AD, Lawrence $D$, Tsao $H$. The RAS/mitogen activated protein (MAP) kinase pathway in melanoma biology and therapeutics. Biologics. 2007 Dec;1(4):407-414.

Jovanovic B, Kröckel D, Linden D, Nilsson B, Egyhazi S, Hansson J. Lack of cytoplasmic ERK activation is an independent adverse prognostic factor in primary cutaneous melanoma. J Invest Dermatol. 2008 Nov;128(11):2696-2704.

Kuphal S, Bosserhoff A. Recent progress in understanding the pathology of malignant melanoma. J Pathol. 2009 Dec; 219(4): 400-409.

Lee YJ, Nagai N, Siar CH, Nakano K, Nagatsuka H, Tsujigiwa H, Roan CH, Gunduz M. Angioarchitecture of primary oral malignant melanomas. J Histochem Cytochem. 2002 Nov;50(11):1555-1562.

Lengyel E, Gilde K, Remenár E, Ésik O. Malignant mucosal melanoma of the head and neck - a review. Pathol Oncol Res. 2003 Apr; 9(1): 7-12.

Leon P, Daly JM, Synnestvedt M, Schultz DJ, Elder DE, Clark WH Jr. The prognostic implications of microscopic satellites in patients with stage I melanoma. Arch Surg. $1991 \mathrm{Dec} ; 126(12):$ 1461-1468.

Lourenço SV, Sangueza MA, Sotto MN, et al. Primary oral mucosal melanoma: a series of 35 new cases from South America. Am J Dermatopathol, 2009; 4: 323-330. 
Maldonado JL, Fridlyand J, Patel H, Jain AN, Busam K, Kageshita T, Ono T, Albertson DG, Pinkel D, Bastian BC. Determinants of BRAF mutations in primary melanomas. J Natl Cancer Inst. 2003 Dec 17;95(24):1878-1890.

Mendenhall WM, Amdur RJ, Hinerman RW, et al. Head and neck mucosal melanoma. Am J Clin Oncol. 2005 Dec;28(6):626-30.

Mirmohammadsadegh A, Mota R, Gustrau A, Hassan M, Nambiar S, Marini A, Bojar $H$, Tannapfel A, Hengge UR. ERK1/2 is highly phosphorylated in melanoma metastases and protects melanoma cells from cisplatin-mediated apoptosis. J Invest Dermatol 2007; 127(9):2207-2215.

Omholt K, Platz A, Kanter L, Ringborg U, Hansson J. NRAS and BRAF mutations arise early during melanoma pathogenesis and are preserved throughout tumor progression. Clin Cancer Res 2003; 9(17): 6483-6488.

Palmieri G, Capone M, Ascierto ML, Gentilcore G, Stroncek DF, Casula M, Sini MC, Palla M, Mozzillo N, Ascierto PA. Main roads to melanoma. J Transl Med. 2009 Oct $14 ; 7: 86(1-17)$

Patel SG, Prasad ML, Escrig M et al. Primary mucosal malignant melanoma of the head and neck. Head Neck. 2002 Mar;24(3):247-57. 
Prasad ML, Patel SG, Huvos AG, Shah JP, Busam KJ. Primary mucosal melanoma of the head and neck. A proposal for microstaging localized, stage I (lymph nodenegative) tumors. Cancer. 2004 Apr; 100: 1657-1664.

Rapidis A, Apostolidis C, Vilos G, Valsamis S. Primary malignant melanoma of the oral mucosa. J Oral Maxillofac Surg. 2003 Oct; 61: 1132-1139.

Rapini RP, Golitz LE, Greer RO Jr, Krekorian EA, Poulson T. Primary malignant melanoma of the oral cavity. A review of 177 cases. Cancer. 1985 Apr; 55: 15431551.

Richmond-Sinclair NM, Lee E, Cummings MC, Williamson R, Muller K, Green AC, Hayward NK, Whiteman DC. Histologic and epidemiologic correlates of P-MAPK, Brn2, pRb, p53, and p16 immunostaining in cutaneous melanomas. Melanoma Res. 2008 Oct;18(5):336-345.

Saldanha G, Potter L, Daforno P, Pringle JH. Cutaneous melanoma subtypes show different BRAF and NRAS mutation frequencies. Clin Cancer Res 2006; 12(15):44994505.

Scholl FA, Dumesic PA, Barragan DI, Harada K, Charron J, Khavari PA. Selective role for Mek1 but not Mek2 in the induction of epidermal neoplasia. Cancer Res. 2009 May 1;69(9):3772-3778. 
Smalley KS. Understanding melanoma signaling networks as the basis for molecular targeted therapy. J Invest Dermatol. 2010 Jan;130(1):28-37.

Smoller BR. Histologic criteria for diagnosing primary cutaneous malignant melanoma. Mod Pathol. 2006 Feb; 19: S34-S40.

Sortino-Rachou AM, Cancela Mde C, Voti L, Curado MP. Primary oral melanoma: population-based incidence. Oral Oncol. 2009 Mar;45(3):254-258.

Tanaka N, Mimura M, Kimijima Y, Amagasa T. Clinical investigation of amelanotic malignant melanoma in the oral region. J Oral Maxillofac Surg. 2004a Aug; 62: 933937.

Tanaka N, Mimura M, Ogi K, Amagasa T. Primary malignant melanoma of the oral cavity: assessment of outcome from the clinical records of 35 patients. Int J Oral Maxillofac Surg. 2004b Dec; 33(8): 761-765.

Thomas NE. BRAF somatic mutations in malignant melanoma and melanocytic naevi. Melanoma Res 2006;16(2):97-103.

Turner DJ, Zirvi MA, Barany F, Elenitsas R, Seykora J. Detection of the BRAF V600E mutation in melanocytic lesions using the ligase detection reaction. J Cutan Pathol. 2005;32(5): 334-339. 
Uribe $\mathrm{P}$, Andrade L, Gonzalez S. Lack of association between BRAF mutation and MAPK ERK activation in melanocytic nevi. J Invest Dermatol. 2006 Jan;126(1):161166.

van 't Veer LJ, Burgering BM, Versteeg R, Boot AJ, Ruiter DJ, Osanto S, Schrier PI, Bos JL. N-ras mutations in human cutaneous melanoma from sun-exposed body sites. Mol Cell Biol. 1989 Jul;9(7):3114-3116.

Venesio T, Chiorino G, Balsamo A, Zaccagna A, Petti C, Scatolini M, Pisacane A, Sarotto I, Picciotto F, Risio M. In melanocytic lesions the fraction of BRAF V600E alleles is associated with sun exposure but unrelated to ERK phosphorylation. Mod Pathol. 2008 Jun;21(6):716-726. 